\title{
FOTOGRAFIA: \\ fragmentação e condensação do tempo na interface homem-máquina
}

Tese apresentada à Escola de Comunicações e Artes da Universidade de São Paulo, Programa de Pós Graduação em Ciências da Comunicação, como exigência parcial para obtenção do título de Doutor em Ciências da Comunicação.

Orientador: Prof. Dr. Mauro Wilton de Sousa

São Paulo

2006 
Nino (in memoriam) e Tê

Agradecimentos

Prof. Eduardo Peñuela

Prof. Mauro Wilton de Sousa

Ângela Barbour

Ana Elisa Rodrigues Bueno

Luiz Filipe Galliano

Maria da Graça Rodrigues Bueno

Sérgio Guerini 
Banca Examinadora

Nome do autor: Fernando Pasquale Rocco Scavone

Título: Fotografia: fragmentação e condensação do tempo na interface homem-máquina Data: 


\section{RESUMO}

Constituem o objeto deste estudo as interações temporais do homem com a máquina na prática do processo fotográfico. Baseado em experiências empíricas e buscando referencias em análises críticas, estrutura-se na sobreposição de três níveis conceituais: sintático, semiótico e psíquico, procura compreender as implicações que as transformações técnicas determinam na linguagem visual do meio.

Palavras-chave:

Fotografia. Imagem. Tempo. Sintaxe. Semiótica. Máquina 


\begin{abstract}
The object of this study is to examine the time interactions between the photographer and the camera through the photographic process.

Based on empirical observations and referring to critical analyses, it is structured in three different conceptual layers: syntactic, semiotic and psychic.

It aims to understand the implications that technical transformations determine in the medium visual language.
\end{abstract}

Key words

Photography. Image. Time. Syntax. Semiotics. Camera 
Índice

Introdução 1

Capítulo 1 - Antecedentes 4

Capítulo 2 - Evolução dos equipamentos 34

Capítulo 3 - Tempo $\quad 91$

Capítulo 4 - Origens 101

Capítulo 5 - Prática 140

Conclusão 176

Referências 183 
Introdução 
A rápida difusão dos sistemas digitais vem provocando crescimento exponencial na quantidade de imagens produzidas. A universalização do acesso ao meio trouxe consigo a banalização. Ocorre que essa tendência, que já era anterior, vem apenas se exacerbando.

Parece, contudo pouco prudente decretar a falência do meio. Com efeito, se o telefone provocou certo abandono das missivas, por outro a internet revigorou o uso da palavra escrita. Tudo indica que o problema era do correio e não do telefone que continua bem mesmo com achegada dos celulares.

No caso da fotografia, verifica-se completa desacralização do meio, mas ela não é essencialmente diferente do que aconteceu quando a difusão dos sistemas digitais em outros contextos liquidou, por exemplo, com o prestígio dos datilógrafos em geral.

O momento parece oportuno para tentar compreender as transições determinadas pela evolução dos sistemas analógicos que agora se esgotam, observando as tendências desenhadas pelo advento dos sistemas digitais, para tentar vislumbrar possíveis vetores no uso do meio.

Partimos da constatação de que certas estruturas são por demais elementares para que se modifiquem como decorrência de evoluções técnicas. É o caso das relações existentes entre os níveis físicos e perceptuais. Assim, muda o equipamento, mas a luz e o olho continuam os mesmos. Mas, num período de rápidas mudanças, pode parecer que aquilo que não muda é porque não existe. O perigo de acreditar que só existe aquilo que se conhece é a inevitável sensação de onisciência.

A fotografia se insere em um contexto de comunicação e assim sua matéria prima é antes de tudo a informação. Isso pode fornecer a pista para a busca de modelos assemelhados no contexto da informática.

Procuramos então compreender o que poderia ser o equivalente a um sistema operacional que rodasse sobre o hardware fotográfico, não na especificidade do próprio equipamento digital, mas no contexto mais amplo da informação. Em seguida, é preciso pensar no que se aplica sobre essa camada básica, em termos de processo, e assim sucessivamente.

Neste trabalho, partimos de um modelo que já tem mais de 50 anos e foi pensado inicialmente para tentar compreender a informação nos sistemas clássicos de gravura. Esse modelo serviu posteriormente como base para uma elaboração evolutiva aplicada especificamente aos modelos fotográficos, que mais de vinte anos após sua publicação continua sendo obra de referência, o que indica boa solidez conceitual. 
A etapa seguinte no presente trabalho foi procurar aplicar outras análises teóricas sobre o substrato desse modelo. Isso foi possível, pois em muitos casos essas análises, mesmo se colocando como fundamentais, estavam em um nível mais elevado, o que permitia estabelecer relações com outros mais elementares sem lhes comprometer a validade.

À medida que se vai afastando das estruturas elementares cresce o nível de abstração e muitas vezes junto com ele a subjetividade. O perigo em empreitadas dessa natureza é se perder o foco específico.

Assim, não devemos perder de vista que o objeto aqui é o sistema fotográfico. Quando encontramos relações, por exemplo, de fundo psicanalítico, é preciso compreende-las em sua forma geral, evitando a tentação de começar a fazer a psicanálise da produção individualizada.

Definida esta baliza, procuramos em seguida chegar a relações gerais que apontem tendências, analisando a prática do meio e as relações de dependência que nele se estabelecem.

Como em todo trabalho que se propõe a operar com tendências, é praticamente impossível falar em conclusão, mas o presente trabalho levanta considerações que poderão ser utilizadas para desenvolvimentos posteriores, assegurando-se pois a natureza fragmentária e dinâmica do tempo nesse processo de informação visual, o que dá título ao presente estudo. 
CAPITULO 1

Antecedentes 
1 - Antecedentes

\section{Antecedentes}

Cheguei à ECA na turma de 1972, sem saber direito que curso iria fazer... A partir do ano seguinte virei freqüentador assíduo do laboratório fotográfico que já ocupava o local onde está até hoje, mas com divisões de espaço e instalações diferentes.

O interesse pela fotografia já existia desde uns 4 ou 5 anos antes, mexendo com câmaras antigas de meu pai e de minha tia e com um pequena Kodak Rio 400 que havia ganho de presente. No laboratório há o contato com o formato $35 \mathrm{~mm}$, em especial as câmaras Leica $\mathrm{M}$ e Leicaflex. A descoberta dos trabalhos de muitos fotógrafos e, em particular, uma das paixões do professor Carlos Moreira, responsável pela área naquele tempo, os trabalhos de Henri Cartier-Bresson, autor das fotos do primeiro livro de imagens que comprei na Fotóptica da Rua Conselheiro Crispiniano.

Achávamos fascinante a plástica das imagens de Cartier-Bresson e, junto com alguns colegas, tentávamos obter algum resultado parecido, procurando utilizar materiais e processos semelhantes, como os filmes Agfa Isopan processados com o revelador Rodinal, e fazendo cópias sobre diferentes tipos de papéis fotográficos revelados com fórmulas comerciais ou encontradas nos livros e revistas, mas quase sempre preparadas de forma artesanal no próprio laboratório.

O Museu da Imagem e do Som tinha sido criado há pouco tempo e estava começando a montar seu acervo. O diretor do museu era o professor Rudá de Andrade, do CTR e nesse projeto trabalhava com ele um aluno que estava concluindo o curso de cinema: Carlos Augusto Calil. 
Esse grupo de alunos que passava boa parte do tempo no laboratório foi convidado para trabalhar na tarefa de formação do acervo inicial do Museu da Imagem e do Som. Contratados pela Secretaria da Cultura, fazíamos reproduções fotográficas de centenas de imagens de época cujos negativos eram organizados em álbuns e ampliações destinadas à consulta na biblioteca do MIS. A perspectiva desse trabalho era interessante no sentido de reproduzir fotografias e outras imagens antigas, muitas vezes deterioradas, com a preocupação de fazer com que essas reproduções não viessem elas mesmas também a se deteriorar. Procurávamos estudar as condiçóes de processamento adequadas para a finalidade de arquivamento à que as cópias se destinavam. Com o passar do tempo, boa parte das pessoas que se envolvia com a fotografia acabava instalando laboratórios fotográficos em suas casas, mais ou menos improvisados, dependendo das possibilidades e, assim, acabei organizando meu laboratório que ficava ao lado do quarto em que dormia.

Nessa época, começamos a experimentar o uso de técnicas de processamento reversível usando conjuntos prontos de químicos preparados para revelar filmes coloridos Kodak Ektachrome e produtos compatíveis produzidos por outras empresas. Os fotogramas em formato $35 \mathrm{~mm}$, montados individualmente em molduras para projeção, eram conhecidos como "slides".

A denominação "reversível" deve-se à forma como se produz a imagem positiva nesses materiais. Durante a etapa inicial do tratamento, um banho revelador produz uma imagem em prata, monocromática e negativa, sobre cada uma das três camadas sensíveis do filme, de forma semelhante à imagem de um filme negativo em preto e branco. A parte da emulsão que não se transformou em prata metálica durante essa operação representa o complemento da imagem negativa formada, sendo 
então positiva. Em etapa posterior do processo, revela-se essa parte da emulsão que representa o inverso do negativo, usando uma solução reveladora que contem um agente específico para liberar a formação dos corantes.

Existia também um filme, fabricado pela Agfa-Gevaert na Bélgica, específico para a produção de slides em preto e branco, que oferecia resultados plasticamente muito interessantes, exibindo uma longa escala tonal, com sombras profundas, impossíveis de se obter nas cópias sobre papel. Os problemas com esse material eram a disponibilidade errática e o preço bastante elevado, além da baixa sensibilidade. Para contorná-los procuramos adaptar fórmulas encontradas na literatura técnica com o objetivo de gerar slides sobre filmes projetados originalmente para uso na forma de negativos, como o Kodak Panatomic-X e até filmes de alta sensibilidade como o Kodak Tri-X, Agfa Isopan Ultra e Ilford HP-4.

Evidentemente, no laboratório fotográfico havia ambientes com vedação total de luz, no entanto, a sala de acabamento, de dimensões modestas, não era um deles. Nessa sala pequena e bastante clara por causa das grandes janelas, a solução que encontramos para visualizar os slides foi projetar uma imagem em dimensões relativamente pequenas (até por causa do tamanho da sala) sobre uma folha de cartolina preta, utilizando um projetor comum da escola, com lâmpada bastante potente, que era usado normalmente nos auditórios. A sensação visual dessas imagens pequenas, muito nítidas e luminosas, observadas em ambiente claro, era muito diferente das imagens da televisão colorida, de surgimento recente na época, antecipando as imagens que nos acostumaríamos a ver nas telas dos computadores, cerca de 20 anos depois, a partir da chegada dos monitores padrão Super VGA.

Quando estava concluindo o curso de cinema na ECA, faltando as inevitáveis dependências acumuladas ao longo dos diversos projetos de 
filmes, fui chamado pelo Prof. Rudá para trabalhar na área de som do MIS. Mesmo assim, o contato era contínuo tanto com as atividades do laboratório fotográfico como com os diversos materiais do acervo, na biblioteca do museu.

Algum tempo depois, e ainda antes de sair do MIS, comecei a trabalhar no laboratório de restauração da Cinemateca, dentro do parque do Ibirapuera. Lá, a encrenca era bem mais complexa, pois além das questões da imagem em si, havia os problemas de deterioração que provocavam alterações físicas nas propriedades do suporte dos filmes, como as variações dimensionais que impediam o corrimento dos filmes nas máquinas de limpeza e copiagem.

Mais tarde, ao redor de 1980, parte das instalações da Cinemateca é transferida para duas casas situadas dentro do Parque da Conceição, no Jabaquara. Numa dessas casas, um espaço próximo à biblioteca foi destinado à instalação de um laboratório fotográfico. Também nessa época, é editado o livro "The Keepers of Light” de William Crawford, com o subtítulo "A History \& Working Guide to Early Photographic Processes" que, até hoje, continua sendo obra de referência sobre processos fotográficos antigos e que então foi adquirido para o acervo da biblioteca da Cinemateca. Nessa obra, Crawford estabelece o conceito de sintaxe visual, que usaremos com freqüência mais adiante.

Em 1982 comecei a trabalhar com fotografias coloridas em sistema negativo-positivo. Diferente do processo reversível onde há relativamente pouco controle sobre as imagens formadas durante a revelação, a etapa de copiagem oferece muitos recursos de controle sobre as imagens finais obtidas em papéis ou transparências.

Os procedimentos de copiagem em cores são muito diferentes dos utilizados com os materiais em preto e branco, pois sendo os materiais 
sensíveis à luz de todas as cores, não se pode utilizar a clássica iluminação monocromática, tipicamente vermelha, empregada nas operações em preto e branco, devendo tudo ser feito em escuro absoluto. A única luz de segurança permissível era tão fraca que apenas possibilitava discernir o vulto dos equipamentos e isso após muitos minutos de acomodação visual.

No processo colorido, mesmo que fosse possível utilizar um ambiente mais claro, não seria possível o controle das cópias por acompanhamento visual durante a revelação como se fazia habitualmente com as cópias em preto e branco, pois durante a etapa de revelação, onde surge a imagem, forma-se uma imagem em prata junto com a imagem colorida e que só em etapa posterior será removida. Mesmo assim a cópia, enquanto molhada, apresenta um aspecto azulado e opalescente que torna qualquer avaliação problemática antes de se completar a secagem. As soluções dos processos coloridos são ainda muito mais suscetíveis à oxidação e operam em temperaturas mais elevadas e tempos mais curtos, o que também conduz a técnicas de trabalho em que as etapas de processamento são controladas através de parâmetros de tempo, temperatura e agitação, de forma bastante semelhante ao que se faz durante a revelação dos filmes negativos em preto e branco pancromáticos que, sendo sensíveis à luz de todas as cores, tampouco permitem controle visual.

Tudo isso faz com que o procedimento de copiagem seja realizado através de geração de conjuntos de cópias de prova para avaliação e decisão, antes de gerar a cópia final de cada imagem. Nas imagens coloridas o espaço de variação é evidentemente muito maior do que no preto e branco, já que além dos parâmetros de luminosidade e contraste no claro-escuro, surgem questóes de matizes e contrates cromáticos que apresentam comportamentos muito distantes de qualquer linearidade. A combinação da rigidez técnica dos processos com essas rotinas de 
avaliação de provas sucessivas coloca os operadores diante de um quadro de alterações sutis que exigem decisões ao mesmo tempo complexas e intuitivas.

Em 1983, comecei a dar aulas nas disciplinas de fotografia de vários cursos como Jornalismo, Publicidade e Relações Públicas no Instituto Metodista, em São Bernardo do Campo. Eram cursos básicos que procuravam transmitir conhecimento sobre os fundamentos dos processos e familiarizar os alunos com o uso de câmaras e operações de laboratório preto e branco. A grande maioria dos alunos mostrava particular interesse pela parte prática, mas ficava evidente que apenas alguns poucos iriam prosseguir trabalhando efetivamente com aquilo, muitos se dispersariam pelas opções de outras atividades das diversas áreas.

A abordagem técnica das disciplinas de fotografia mostrava-se claramente insatisfatória. A preocupação com ajustes técnicos mínimos era bem maior do que a diferença sutil produzida nos resultados que, frequentemente passava despercebida. E, principalmente, ficava evidente que tratando sempre das variáveis apenas aos pares, não havia clareza na interdependência dos diversos fatores.

O raciocínio simplista baseado em dualidades esconde relações bem mais complexas da estrutura do sistema. Algumas dessas dualidades são muito conhecidas, até em excesso, o que faz com que certas outras relações acabem sendo esquecidas. Uma dessas relações muito conhecidas é a que estabelece o princípio geral da reciprocidade na exposição. A quantidade de energia luminosa que produz o registro da imagem resulta de um produto da intensidade luminosa pelo tempo de exposição. Essa relação expressa por $\mathrm{E}=\mathrm{I} \times \mathrm{T}$ é linear dentro de certa faixa, e o desvio na relação, ao se distanciar dessa faixa, é conhecido como "falha de reciprocidade". Assim, ao abrir o diafragma, se aumenta a intensidade da 
luz que atinge a emulsão. Sendo essa luz mais intensa, a fim de manter constante a exposição deve-se reduzir proporcionalmente o tempo em que o obturador permanece aberto.

Outra dualidade muito conhecida relaciona a abertura de diafragma com a profundidade de campo. Deste modo, por exemplo, para aumentar a profundidade de campo, pode-se fechar o diafragma. Mas tal procedimento exige que o tempo de exposição aumente. Há, portanto, uma relação entre a profundidade de campo e o tempo de exposição, mas essa é uma das relações que quase nunca são evidenciadas.

Havia começado a fazer mestrado na ECA quando surgiu a idéia de desenvolver uma proposta para as disciplinas de fotografia desenvolvida a partir de conceitos encontrados na obra de Crawford. A proposta era analisar as relações existentes entre os diversos parâmetros técnicos do processo fotográfico como um todo, estabelecendo um modelo multidimensional que permitisse avaliar as influências na imagem decorrentes das opções de ajustes desses diversos valores.

A idéia era usar uma abordagem não estritamente quantitativa, mas mostrar que as decisóes tomadas dentro dos limites permitidos pela sintaxe representavam sempre soluções de compromisso entre as diversas variáveis envolvidas.

O modelo utilizado considerava, seguindo conceitos de sintaxe de Crawford, os seguintes parâmetros:

1 - Intensidade luminosa

2 - Resolução espacial

3 - Resolução temporal

4 - Resolução de malha

5 - Escala de reprodução 
É interessante observar que esse último parâmetro, a escala de reprodução, designada comumente pela variável identificada como $\mathrm{M}$ (Magnification, em inglês) só fica evidente quando se faz a análise da correlação simultânea da profundidade de campo com a distância focal e a distância do assunto.

É claro que, a influência de certos fatores depende de situações específicas, pelo menos em grupos ou classes distintas, podendo chegar até mesmo a situações muito particulares. Como no caso de uma natureza morta, por exemplo, em que o tempo de exposição pode ser irrelevante. Mas isso deixa de ser verdade se, nessa cena for visível uma taça com vinho espumante, pois nesta situação específica, o tempo de exposição influencia as características da imagem registrada. Ainda que a cena seja essencialmente estática, o líquido dentro da taça apresenta uma característica dinâmica.

Nesse modelo, o registro fotográfico situa-se então como um ponto dentro de espaço multidimensional. Como o registro fotográfico se faz a partir da energia luminosa que atinge a superfície sensível, não é de se estranhar que ao final de tudo surja uma relação entre a quantidade de energia e a quantidade de informação registrada.

Acaba ficando claro também nesse modelo, que grande parte dos registros se dá em posições situadas a uma distância considerável dos limites determinados pelo nível corrente da tecnologia em uso, de que fala Crawford.

A abordagem se dá operando sobre as diversas variáveis de forma aproximativa, avaliando tendências introduzidas nas características da imagem registrada. Desta forma, ao fechar o diafragma tende-se a privilegiar a nitidez espacial, isto é, a profundidade de campo, mas devese aceitar compromisso equivalente na variável de nitidez temporal que 
está ligada ao tempo de exposição. Se quisermos aumentar a profundidade de campo, sem diminuir o tempo de exposição, será preciso usar uma emulsão com maior sensibilidade à energia luminosa. As características de granulação dessa superfície mais sensível representam compromisso na resolução de malha.

Prosseguindo, se quisermos agora manter fixas as três variáveis simultaneamente, será preciso aumentar o nível de energia do sistema, conforme mencionado acima. Ou então, diminuir a escala de reprodução. Como veremos mais adiante, esta última alternativa acarretará muitas implicações importantes.

Infelizmente não houve possibilidade imediata de experimentar o uso didático do modelo, pois acabei saindo da metodista antes de concluir o trabalho. Entretanto, o modelo passou a servir como base para pensar as atividades de produção fotográfica do cotidiano profissional.

Por volta de 1984, antes mesmo de sair da Metodista, junto com meu irmão havia começado a operar um estúdio que produzia fotografias de documentação industrial e publicitária, além de atender a alguns artistas plásticos, fazendo registros fotográficos de suas obras. O nível de exigência não apenas técnica, mas também comercial desses setores fazia com que, no período entre 1985 e 1996, a maior parte dos trabalhos fosse feita em formatos maiores que o de $35 \mathrm{~mm}$. Especialmente, sobre filmes em formato 120 e chapas de 4 x 5 polegadas. Ocasionalmente, até em chapas $5 \times 7$ polegadas, gigantescas para os padrões de hoje. Essas chapas eram expostas em câmaras profissionais de fole das marcas Fatif (italiana) e Linhof (alemã). Essas câmaras, mesmo dotadas de sofisticados recursos de geometria variável que permitiam controles óticos e de perspectiva bastante complexos, são até hoje semelhantes em sua essência às câmaras escuras dos primeiros fotógrafos, e sua operação 
pode dar uma boa idéia de como as coisas aconteciam há mais de um século.

No caso dos filmes em rolos, nos formatos 120 (e mais raramente 220), com largura de cerca de $6 \mathrm{~cm}$, eles eram usados tanto em câmaras reflex Ashi Pentax, no formato $6 \times 7 \mathrm{~cm}$, quanto em magazines que se encaixavam no montante posterior das câmaras de fole.

O formato $35 \mathrm{~mm}$, que era padrão nas atividades de jornalismo (e assim permanecendo até sua recente substituição pelos sistemas digitais) tinha participação menor, mas não deixou de ser utilizado. Nessa época em que não havia ainda o PowerPoint, as apresentações eram ilustradas com seqüências de slides, acompanhadas em alguns casos por uma trilha sonora, sendo essa combinação conhecida pelo apropriado nome de "audiovisual".

A produção de trabalhos em formatos tão diversos evidenciava claramente as diferenças nos procedimentos adotados para cada um deles, nos mais variados aspectos.

Um desses aspectos, por exemplo, era a diferença na potência do parque de luz que era necessário para permitir o trabalho nos diversos formatos. Para fotografias feitas em formato $35 \mathrm{~mm}$, unidades de flash com potência de 400 Watt-segundo eram suficientes, enquanto que para o formato $6 \times 7 \mathrm{~cm}$, usavam-se unidades com pelo menos o dobro da potência. O uso dos formatos maiores exigia equipamentos com potência de até 5.000 Watt-segundo.

Tal fato, que poderia parecer apenas uma idiossincrasia do sistema, encontrava, dentro do modelo, explicação na maior quantidade de informação registrada em cada imagem e essa quantidade relacionava-se 
com a escala de reprodução. Bastante lógico, afinal: formato maior, escala de reprodução maior, mais informação, mais energia no sistema.

Nessas operações com formatos grandes, especialmente no caso das chapas, o conceito de instantâneo só se aplicava muito raramente, mesmo quando eram usados flashes eletrônicos para iluminar a cena. Muitas vezes, quando a potência das unidades de flash era insuficiente, a exposição era feita por meio de uma série de disparos sucessivos de flash, descartando qualquer idéia de "instante", de forma equivalente aos tempos longos de exposição, sob iluminação contínua.

A potência dos equipamentos de iluminação, dentro de cada classe, tem relação direta, mas quase nunca linear, com o custo. Mesmo não sendo considerada academicamente relevante, essa poderia ter sido ser mais uma variável a ser agregada ao modelo.

A fotografia com chapas impóe uma seqüência muito definida de operações. Inicialmente, se estabelece o enquadramento. Depois a etapa de ajuste de foco, que nesses equipamentos com recursos de basculagem dos montantes pode ser muito complexa e demorada.

As objetivas utilizadas nesses formatos costumam apresentar aberturas máximas da ordem de $\mathrm{f} / 5,6$, bem pouco luminosas quando comparadas com as objetivas usadas em formatos menores. A luminosidade das imagens formadas no vidro despolido é, portanto bastante baixa. Frequentemente são utilizadas luzes adicionais, "de serviço", fortes e dirigidas, apenas para auxiliar na visualização, durante as operações de enquadramento e focalização. Até aqui, mantém-se em geral a objetiva na sua abertura máxima.

Em seguida, vêm os cálculos e ajustes de exposição. Nessa hora, fecha-se o diafragma para a efetiva abertura de trabalho e no vidro despolido a 
imagem escurece de forma considerável. O chassi com a chapa é montado na câmara e o obturador deve ser fechado antes de ser retirada a lâmina metálica que protege da luz a superfície sensível.

Uma vez completada a exposição, a lâmina de proteção é recolocada; retira-se o chassi que recebe uma identificação, marcando-o como exposto; e volta-se a abrir o obturador e o diafragma. Só neste momento é que a imagem volta a ser visível no vidro despolido.

A descrição acima deve ter deixado claro que, ao trabalhar com equipamentos desse tipo, há uma seqüência bem determinada de operações, com etapas bem definidas. Podemos distinguir com clareza que há um tempo no qual se resolvem aspectos de enquadramento, composição e foco. E um outro tempo, subseqüente, em que se cuida dos ajustes de exposição e da operação de registro, propriamente dita. Essas operações são relativamente demoradas e as chapas de formato grande são também bastante custosas. Cada operação mal-sucedida custa muito em termos de tempo e de materiais.

Fotografar com câmaras que usam filmes em rolos apresenta uma situação bastante diferente, principalmente quando se usam filmes para formatos pequenos de imagem.

Antes de tudo, a redução do formato tem uma série de implicações em cadeia: quanto menor o formato, menor será a escala de reprodução, menor será a área de filme que irá receber a energia luminosa para produzir o registro. Esse conjunto todo conduz na direção de um registro que se faz com uma quantidade menor de energia. Na prática, isso se traduz por condições mais favoráveis na profundidade de campo, ou por tempos menores de exposição, ou aberturas menores de diafragma, ou qualquer combinação que se faça desses parâmetros. $O$ fato é que, permanecendo inalteradas as demais características, a diminuição do 
formato da imagem se traduz por uma redução global na quantidade de informação registrada e, por conseqüência, na quantidade de energia exigida para fazer o registro.

$\mathrm{Na}$ prática, fotografar com formatos pequenos significa melhor possibilidade de se obter registros sob condições adversas de luz. Usar equipamentos menores significa maior mobilidade e agilidade. $\mathrm{O}$ desenvolvimento desses equipamentos procura valorizar esses aspectos.

Dentro do corpo da câmara, o pedaço do rolo de filme sobre o qual será registrada a cena ocupa o lugar onde a objetiva forma a imagem. Isso impede, em princípio, que essa imagem seja usada para enquadramento e focalização, tornando necessário algum dispositivo auxiliar para o enquadramento e a focalização. Esse visor pode até ser muito simples, como um mero arame dobrado formando uma espécie de moldura para a cena.

Para a focalização, seria suficiente uma escala calibrada.

Essa era a situação das primeiras câmaras para filmes em rolos e nos modelos muito simples e econômicos pouca coisa mudou desde então. Mesmo assim, a evolução nas técnicas de fabricação, junto com a produção em larga escala, fez com que a maior parte dos aparelhos ofereça soluções bem mais sofisticadas.

Seja como for, a imagem no visor permanece agora disponível para o fotógrafo pelo menos até o momento exato do disparo. Dependendo da solução construtiva do equipamento, continuará sempre visível ou desaparecerá no momento em que o botão de disparo do obturador for acionado. Mesmo assim, na quase totalidade dessas câmaras, a imagem volta a ser exibida tão logo se completa a exposição do filme, com a exceção de alguns poucos equipamentos que exigem o acionamento de uma alavanca para que isso aconteça. 
Observamos aqui as primeiras diferenças significativas entre fotografar usando câmaras para chapas e câmaras para filmes em rolos.

1) Nas câmaras para filmes em rolos, a composição e a focalização da imagem que será registrada, não são mais realizadas no próprio local em que ficará a superfície sensível que registrará a imagem, mas sim através de um dispositivo auxiliar conhecido como visor.

2) O uso do visor permite que a imagem permaneça visível praticamente durante todo o tempo, inclusive durante os ajustes, e, muitas vezes, mesmo durante a própria exposição.

Ao fotografar com câmaras para chapas, não existe mais uma divisão nítida entre as etapas de enquadramento e focalização, por um lado, e as etapas de ajuste e registro da imagem, por outro. O tempo de composição e enquadramento pode agora se estender até o momento em que o disparador é acionado.

E logo após, uma vez completada a exposição, é possível se voltar em pouco tempo ao tempo de captação. É claro que isso não acontece de forma obrigatória, mas a possibilidade agora existe, e a distância que separa o fim de um ciclo de operações do início do seguinte reduz-se ao tempo que leva para fazer o transporte do filme até a posição da chapa seguinte. Quanto mais rápido isso acontecer, mais depressa ele poderá iniciar o ciclo fotográfico seguinte. Novamente, com o passar do tempo e com o desenvolvimento técnico dos equipamentos, esse intervalo tende a zero, praticamente desaparecendo, pelo menos enquanto o filme dentro da câmara não chegar ao fim.

O padrão denominado 120 permite, conforme o formato das imagens, entre 8 e 16 fotografias por rolo de filme. No caso do padrão 135, que utiliza filme perfurado com largura de $35 \mathrm{~mm}$, produziam-se cartuchos 
com diversos comprimentos permitindo registrar até 36 fotogramas no tamanho padrão de $24 \times 36 \mathrm{~mm}$. Alguns equipamentos utilizavam esses mesmos filmes para registrar imagens em um subformato conhecido como "meio-quadro", com 18 × $24 \mathrm{~mm}$, o que permitia obter até 72 fotos por filme.

Parece claro que a diminuição do formato do filme possibilita aumento da autonomia da câmara fotográfica, aqui entendida como a capacidade de produzir ciclos continuados de fotos, sem uma obrigatória interrupção longa para a operação de troca de filme. Para o fotógrafo isso significa que, durante certo tempo, o final de cada ciclo de captação desemboca no início do ciclo seguinte. É evidente que não é obrigado a continuar fotografando, mas a possibilidade existe e acaba, muitas vezes, sendo usada.

Na segunda metade da década de 1980, como exposto acima, usávamos para as atividades profissionais de fotografia em estúdio ou locações, equipamentos de formatos diversos que variavam desde chapas de $5 \times 7$ polegadas (cerca de $13 \times 18 \mathrm{~cm}$ ) até câmaras $35 \mathrm{~mm}$, que já dispunham de transporte motorizado do filme e controle automático da exposição.

Nessa época, os sistemas de focalização automática eram ainda incipientes e muitas vezes mais atrapalhavam do que ajudavam o trabalho. Isso sem contar o elevado custo de equipamentos como o mostrado na foto abaixo, que quase sempre tornava inviável sua aquisição. Por mais paradoxal que possa parecer, as primeiras máquinas que atingiram automatização total, incluindo a focalização, não foram as de uso profissional, mas as destinadas a amadores, porém isso se explica pela maior tolerância aceitável nessa classe de equipamentos. Mesmo assim, esses equipamentos de uso amador logo começaram a determinar mudanças no modo de operação do sistema fotográfico. 
A determinação do formato levava em conta não apenas questóes de exigências de qualidade técnica, mas principalmente de viabilidade operacional e orçamentária. Fotografias fora do estúdio apenas muito raramente eram realizadas usando chapas, sendo em geral preferível dispor da melhor funcionalidade dos filmes em rolos.

Uma das grandes vantagens da combinação de agilidade operacional com custo reduzido oferecida pelos filmes em rolos é viabilizar um grau mais ou menos elevado de redundância nas imagens produzidas. Como sempre existe o risco de acidentes durante o processamento, é normal se produzir fotogramas adicionais como garantia. Na mesma linha se fazem séries de diversos fotogramas com exposições diferentes, deixando para depois escolher qual deles produziu melhor resultado. Continuando nesse raciocínio, são feitos vários enquadramentos alternativos para em etapa posterior se escolher qual o que atende melhor ao objetivo do trabalho. Tudo enfim, caminha na linha de certo empirismo no qual, diante da inevitabilidade dos erros, o objetivo é garantir a ocorrência dos acertos através do aumento das alternativas.

Isso não teria muita importância não fosse pelo fato de que durante o trabalho, todos os elementos se juntam formando um circuito de realimentação. Cada imagem produzida leva a uma ponderação de como deve ser a seguinte, fazendo com que a fotografia acabada, não seja apenas uma única imagem, mas o produto resultante de todo um processo, durante o qual, muitas outras ficaram pelo caminho, mas constituíram parte relevante do resultado final obtido.

Uma coisa fica clara: a fotografia quase nunca está resolvida no momento em que se aperta o disparador. Muita coisa ainda vai ter acontecer antes dela estar pronta. Ainda que o registro seja efetivamente feito durante apenas uma pequena fração de segundo, muito outros tempos estão envolvidos no processo. A idéia do "instantâneo" fotográfico é bastante simplista e reduz o processo a um mecanicismo que pouca ajuda oferece 
para sua compreensão. No entanto, ela é tão forte que faz com que muitas análises, mesmo que se perceba a complexidade do problema, acabem resvalando, de forma consciente ou não, para essa identificação.

$\mathrm{Na}$ direção contrária da produção de várias imagens semelhantes, e redundantes, até como forma de garantir resultados válidos, a operação estúdio e com formatos grandes se tornava a escolha natural imposta por determinadas exigências específicas, como o caso das exposições múltiplas. Fotografias de imagens exibidas em cinescópios produzem em geral melhor resultado quando feitas em ambiente totalmente escurecido. Mas, nessa condição, só se consegue registrar a própria imagem luminosa e não o equipamento em que ela está sendo exibida. Hoje, a solução óbvia é produzir duas imagens diferentes: uma, do aparelho, iluminado de forma adequada e outra, da imagem luminosa registrada no escuro para depois combiná-las usando um editor digital de imagens. Pensando bem, essa não seria propriamente a solução mais atual, mas aquela de algum tempo atrás. Provavelmente hoje, a imagem do cinescópio não seria mais sequer fotografada, mas apenas "capturada" digitalmente.

Mesmo cerca de quinze anos atrás, tal combinação de imagens poderia ser feita em laboratório através de um complexo processo de copiagem, usando máscaras e contra máscaras, conhecido como "fusão cromática", que usava operações baseadas nos mesmos princípios empregados pela indústria cinematográfica para a geração de efeitos especiais avançados. O custo elevado dessa técnica limitava sua utilização a casos muito específicos como, por exemplo, combinar a imagem de um automóvel, fotografado em estúdio para permitir o controle dos reflexos nas superfícies brilhantes e curvas, colocando-o em ambiente externo onde seria quase impossível obter tal controle. 
As constrições orçamentárias faziam com que muitos outros casos, como na imagem abaixo, tivessem que ser resolvidos através de múltiplas exposições sobre um mesmo pedaço de filme. Nessas situações, as chapas fotográficas expostas (várias vezes) em máquinas muito semelhantes às primitivas câmaras escuras ofereciam, na época, solução imbatível.

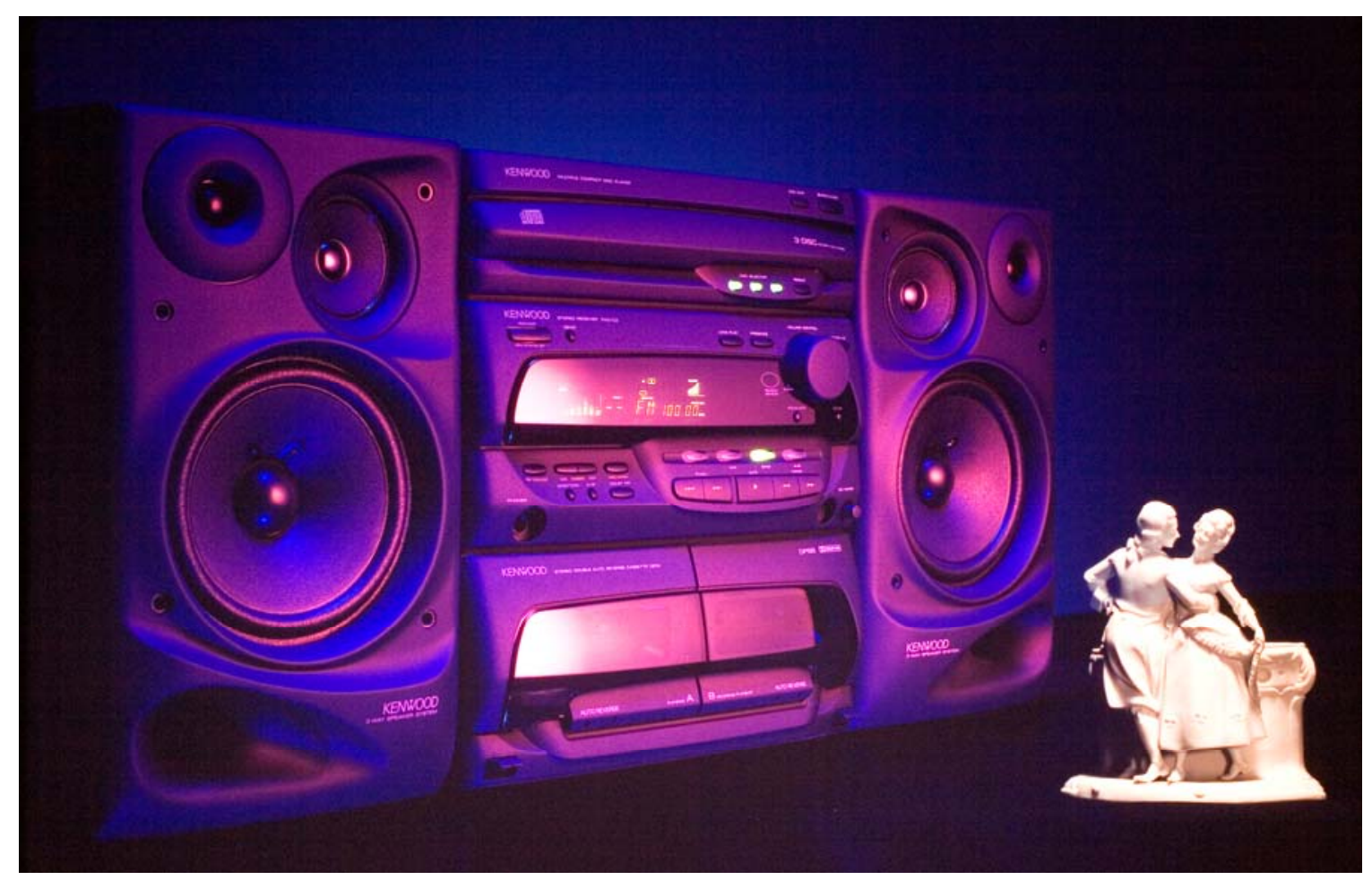

Parece bastante óbvio que o fluxo de trabalho dependia das características do equipamento utilizado, ao mesmo tempo em que se tornava igualmente evidente haver também uma relação entre o formato utilizado e a quantidade de imagens produzidas. Ao fotografar com chapas, a operação era mais demorada e a produção, até por constrições de orçamento, devia se resolver na ordem de algumas unidades. Já no formato $6 \times 7$, sobre filmes padrão 120, a produção girava na casa de dezenas de imagens, enquanto que no formato $35 \mathrm{~mm}$ essa quantidade atingia facilmente a casa das centenas de fotogramas. 
A primeira impressão é que há uma relação inversa entre o tamanho do filme e a quantidade de imagens. Assim, ao utilizar formatos muito pequenos deveria haver uma tendência crescente na quantidade de fotogramas produzidos para cada cena fotografada.

Tal impressão parece ser válida basicamente para os formatos compreendidos entre as chapas e os formatos que utilizam os filmes de 35 milímetros de largura, com perfurações laterais, como os empregados em aplicações cinematográficas. A quantidade de imagens produzidas sobre formatos menores, além de não aumentar, tende pelo contrário a diminuir.

Os cartuchos no padrão 135 eram em geral comercializados em duas versões, com 20 ou com 36 exposições por filme. Os profissionais sempre preferiram a versão mais longa que, além da maior autonomia, era economicamente vantajosa com menor custo unitário por fotograma, o que é compreensível, pois parte do preço final do produto deve-se a custos que não dependem do comprimento do filme, como o da embalagem ou do próprio cartucho.

Posteriormente, na década de 1980, a indústria passou a oferecer versões de 12, 24 e 36 exposições, desaparecendo a versão de 20 fotogramas. Essa alteração foi feita a partir de estudos mercadológicos que mostraram que várias fotos de amadores acabavam se estragando dentro das câmaras enquanto se esperava uma oportunidade para acabar de usar o filme e enviá-lo para o laboratório. Grosso modo, pode-se dizer que a idéia dos fabricantes foi oferecer para os amadores, filmes com quantidade de fotos suficientes para uma festa de aniversário (12), um fim de semana (24) ou para as férias (36).

O formato clássico de 24 x 36 milímetros estabeleceu uma referência que atravessou muitas décadas, tanto para aplicações profissionais como para 
uso amador, respondendo por parcela significativa da produção fotográfica como um todo. A grande autonomia do formato, permitindo fazer até 36 fotos antes de ter que trocar o filme, quase que certamente teve alguma influência nisso. Por outro lado, o subformato de 18 x 24 milímetros, conhecido como "meio quadro", com dimensões próximas às do fotograma cinematográfico, sempre permaneceu no âmbito do uso pelos amadores.

Também não prosperaram algumas tentativas no sentido de aumentar a autonomia, sem diminuir o formato, como a de pelo menos um fabricante que chegou a produzir versões especiais de filmes para aplicações profissionais usando para o suporte um filme de poliéster. Esse material, muito mais resistente do que o suporte normal de tri-acetato de celulose, podia ter espessura mais fina, possibilitando acomodar no cartucho normal um maior comprimento de filme que permitia obter 72 imagens por filme. Esses filmes fora de padrão causavam problemas no mecanismo de transporte das câmaras, além do fato de que as escalas dos contadores de fotogramas não tinham previsão para tal quantidade de imagens, criando mais uma complicação no uso.

Processo reversível e processo negativo-positivo

Grande parte das imagens fotográficas de produção profissional era realizada sobre filmes coloridos reversíveis, do mesmo tipo dos que usávamos para fazer slides no laboratório da ECA nos tempos da graduação.

Essas imagens coloridas, positivas e transparentes eram denominadas genericamente como "cromos" (daí, a operação de combinação de imagens citada anteriormente ser conhecida como "fusão cromática"). $\mathrm{O}$ cromo era a opção natural para produzir fotografias destinadas à 
posterior impressão usando processos foto-mecânicos como no caso de jornais, revistas, cartazes ou catálogos, não se vendo nesses casos a necessidade de negativos já que não seriam produzidas cópias sobre papel fotográfico, ou quando as imagens seriam usadas diretamente para projeção.

Há várias razões consistentes para a opção por esses materiais. No caso das aplicações de foto-jornalismo, os materiais reversíveis respondem, melhor do que os negativos, a um tipo de alteração de tratamento conhecido como "revelação puxada" (mal traduzida do inglês "push processing”) muitas vezes indispensável para o trabalho sob condições precárias de iluminação e com a qual se consegue usar o filme como se ele tivesse sensibilidade maior do que a nominal, especificada pelo fabricante de acordo com as normas técnicas vigentes (na época, ASA e DIN, hoje ISO).

Para as aplicações comerciais e de publicidade, o suporte transparente dos cromos permite imprimir imagens finais com qualidade, em tamanhos maiores do que a partir de cópias sobre papel onde a textura do suporte compromete os detalhes finos da imagem. Outra vantagem importante é a possibilidade da avaliação direta da imagem no que diz respeito ao contraste e às cores, sem precisar de uma etapa intermediária de copiagem. Além de facilitar a comparação com os resultados das provas de impressão produzidas pelas gráficas ou laboratórios de fotolitos ou outras matrizes. Se por um lado, a ausência da copiagem positiva significa a perda de uma oportunidade de controle da imagem, por outro lado, faz do cromo um dos processos em que a imagem está praticamente pronta ao se concluir a revelação do filme.

Havia basicamente três processos para a obtenção de cópias sobre papel fotossensível a partir do cromo. Em dois deles, o cromo era copiado sobre papéis especiais que produziam, depois de processados, imagens diretas 
em positivo. A diferença entre os dois processos estava na estrutura do material de cópia. Enquanto um deles usava um papel com estrutura e processamento semelhantes aos utilizados no próprio filme reversível original, o outro fazia uso de uma emulsão que já continha camadas completas de corantes que, durante o processamento, eram destruídos de forma seletiva e proporcional à intensidade da luz recebida. Nesse processo, desenvolvido pelo grupo químico CIBA e que era conhecido como Cibaprint (ou Cibachrome no caso de cópias sobre suporte transparente), o material de cópia era inicialmente escuro e ia clareando durante o processamento.

No terceiro processo, diferente dos anteriores, o cromo era simplesmente refotografado sobre um filme colorido especial, de baixo contraste, produzindo um negativo de segunda geração, conhecido como "internegativo", a partir do qual se extraiam cópias, normalmente, como a partir de qualquer outro negativo original. Esta era a opção natural quando havia necessidade de produzir certa quantidade de cópias fotográficas a partir de uma mesma imagem.

$\mathrm{Na}$ fotografia colorida, se o uso de filmes reversíveis dominava grande parte da produção profissional destinada a usos gráficos, o processo negativo-positivo era amplamente utilizado em outras aplicações, onde se fariam apenas cópias fotográficas, como retratos, fotos de casamentos ou formaturas, além de responder pela quase totalidade da produção fotográfica dos amadores. $\mathrm{Na}$ fotografia em preto e branco, o processo negativo-positivo tinha, com algumas raríssimas exceções, uso praticamente universal.

A relativa simplicidade do processo em preto e branco fazia com que muitos profissionais fizessem pessoalmente as operações de laboratório. Da mesma forma, alguns amadores instalavam laboratórios próprios, muitas vezes restritos a trabalhar apenas até tamanhos relativamente 
pequenos nas cópias. Sempre era possível encaminhar os filmes para um laboratório externo para fazer cópias em tamanhos maiores ou, se preciso, em maior quantidade. As cópias, tanto de amadores quanto de profissionais, eram quase sempre feitas manualmente, variando talvez mais no tamanho do que em qualquer outro aspecto.

Seleção das imagens

Após a revelação, os filmes são examinados numa mesa de luz, com lâmpadas dentro e um vidro fosco na parte superior, essencialmente semelhante ao negatoscópio, equipamento usado pelos médicos para examinar radiografias.

No caso dos cromos, como dissemos, as imagens estão praticamente prontas e o exame do material produzido se destina quase que apenas a avaliar o conjunto das imagens a fim de selecionar as que apresentam os melhores resultados. No caso de negativos, há ainda pela frente uma operação de copiagem antes de se chegar às imagens finais. Para facilitar a seleção, muitos fotógrafos, em vez de olhar diretamente os negativos, preferem examinar provas positivas em que os negativos são copiados por contato sobre uma folha de papel fotográfico. Com isso, evita-se a dificuldade de avaliar as imagens em tons invertidos, principalmente no caso dos filmes coloridos em que há uma tonalidade avermelhada sobre toda área do filme.

A tira de filme ou a folha de contatos, com as tiras copiadas lado a lado e em ordem seqüencial, além da mera seleção de imagens, permite analisar a seqüência de imagens na ordem em que elas foram feitas. É interessante poder observar como, ao longo do trabalho, foram variando os diversos enquadramentos em função da interação dos movimentos do 
assunto e do fotógrafo, bem como dos diversos ajustes feitos na câmera entre uma foto e outra. Voltaremos a isso depois.

As folhas de contato são usadas também para anotar instruções que servirão como orientação para o laboratorista, ou o próprio fotógrafo, durante a etapa subseqüente de copiagem. Muitas vezes, a opção pelo uso do processo negativo-positivo se faz, não apenas em função da facilidade em produzir múltiplas cópias a partir de um único negativo, mas também pelas possibilidades de operações de controle existentes durante o processo de copiagem. A produção manual de cópias coloridas é um processo complexo e demorado que exige testes para ajustes não só de luminosidade e contraste, mas também de balanço cromático. Isso faz com que seja demorado e caro.

Para viabilizar o uso da fotografia colorida em larga escala pelos amadores seria preciso encontrar meios de tornar as operações mais ágeis e reduzir custos. Surgem então, inicialmente nos Estados Unidos e na Europa, processadoras automatizadas tanto para os filmes quanto para a produção de cópias. Normalmente eram equipamentos de grande porte acessíveis apenas para laboratórios que operassem em escala industrial. Na década de 1980, algumas dessas máquinas usavam bobinas de papel fotográfico com mais de $60 \mathrm{~cm}$ de diâmetro para produzir cópias para amadores, e chegavam a produzir algo como 10 mil cópias por hora. Operando nessas condições era possível chegar a preços bem menores do que os das cópias manuais, mas não havia espaço para a seleção e o controle individual de cada imagem. Muitos laboratórios adotavam uma política comercial em que se estipulava um preço fixo para revelar o filme e copiar todas as fotos. Esse preço era bem inferior ao que se cobrava para copiar individualmente a mesma quantidade de negativos avulsos. Para o amador, o processo de seleção das fotos se resumia a jogar fora aquelas que ele considerava mal sucedidas. As primeiras copiadoras automáticas coloridas apresentavam severas limitações na 
avaliação de balanço cromático. Bastava haver na foto alguma região de área considerável em cor forte para o sistema desviar sensivelmente o balanço cromático da foto na direção oposta. Assim, a foto de uma pessoa fotografada perto de um painel vermelho tendia a ficar verde-azulada.

Com o passar do tempo os equipamentos foram sendo aperfeiçoados. A concorrência fez com que alguns laboratórios em vez de cobrar um preço fixo, estipulassem apenas um preço máximo, do qual se subtraia o custo referente a cópias que tivessem saído tremidas, fora de foco ou drasticamente sub ou superexpostas. Essa tática comercial contava com o fato de que muitas vezes o cliente preferia pagar para ficar com a foto tremida do que obter o desconto, a ter que ver a imagem de alguém querido ser rasgada e jogada no lixo. Provavelmente muitas dessas fotos mal sucedidas não foram efetivamente destruídas, pelo menos não na época em que foram feitas, sendo mais provável terem ficado esquecidas dentro de alguma caixa ou envelope.

As cópias automáticas, junto com câmaras completamente automáticas originalmente pensadas para uso amador, acabaram sendo apropriadas por profissionais, não só da fotografia, que desenvolveram sintaxes próprias para seu uso. Um dos casos mais notáveis é o de David Hockney e suas fotomontagens.

Nos primeiros tempos de atividade fotográfica profissional, usávamos laboratórios externos comerciais para os serviços coloridos, processando no pequeno laboratório doméstico apenas os materiais em preto e branco. Com o passar do tempo, a instalação de um laboratório mais completo junto ao estúdio, permitiu começarmos a revelar primeiro os filmes coloridos, tanto negativos quanto reversíveis e, algum tempo depois, a fazer cópias coloridas em tamanhos pequenos, que serviam como amostras de referência para os pedidos de ampliações encaminhados para produção em laboratórios externos. 
A prática da atividade profissional da fotografia acaba por deixar claro que a operação do sistema como um todo, envolve questóes que se situam muito além das variáveis do modelo de sintaxe de que falamos no início.

Cada etapa do processo exige decisões que, mesmo sendo sempre mais ou menos racionais, mais ou menos intuitivas, são necessariamente de tipos muito diferentes. Em geral, durante a captação há um espaço relativamente aberto pela frente. Como são feitas muitas fotos de uma mesma cena, se a foto que se acabou de registrar por algum motivo não satisfaz, é quase sempre possível continuar fotografando para tentar chegar a um resultado melhor. Claro que isso dentro das constriçóes normais de tempo, suprimentos e, não menos importante, de orçamento. Várias análises do processo fotográfico destacam a sensação de insegurança que domina o fotógrafo diante da situação de ter a imagem já feita, mas não poder ainda vê-la.

É interessante observar que nessa hora se torna evidente uma das grandes diferenças entre o profissional e o amador. Enquanto, com freqüência, este guarda na imaginação a idéia de ter feito uma boa foto e muitas vezes se decepciona ao ver os resultados, a experiência do profissional faz com que suas expectativas sejam mais realistas. Só que essa mesma experiência, que leva o profissional a se pautar quase sempre pelo que sabe produzir resultados garantidos, e provavelmente melhores, ao faltar ao amador, pode levá-lo a certas ousadias que o profissional julgaria pouco prudentes, mas que conduzem, ainda que ocasionalmente, a resultados surpreendentes, acima de suas expectativas.

$\mathrm{Na}$ fase de análise das imagens produzidas, as decisões devem ser tomadas quase sempre sobre um universo definido e fechado de escolha, 
já que, com exceção das fotos feitas no próprio estúdio, deixa de existir a possibilidade de continuar fotografando para obter novas imagens que existia anteriormente.

Mesmo considerando que as cópias são "fotos das fotos", aqui não se trata mais de trabalhar a questão de como tratar a cena que se tem diante dos olhos, mas sim de procurar acomodar o conjunto das imagens disponíveis à lembrança que se tem da cena, não apenas no sentido de como ela realmente era, mas principalmente no que diz respeito ao que se pretendia dizer sobre ela. Há inclusive o perigo de não se perceber a distinção entre essas duas visões e achar que elas tendem a coincidir, levando à atribuição de um excessivo valor documental às imagens. E, quase sempre, à frustração diante dos resultados.

As operações manuais de copiagem, e em particular os controles que elas permitem, estão com certeza entre os maiores fatores geradores das crises que ocorrem comumente entre fotógrafos e laboratoristas (ou pelo menos estavam, até recentemente, quando surgiram as impressoras digitais de cópias fotográficas). Essas crises surgiam sempre que havia exigência de ajustes muito críticos nas cópias. A razão da exigência podia variar, mas as dificuldades de entendimento sempre permaneciam como fator de tensão. As avaliações mais comuns, e infelizmente simplistas, sobre as causas desses desentendimentos acabavam sempre apontando para fatores que oscilavam, de parte a parte, entre a intransigência e a incompetência.

Ao redor de 1990 reformamos o laboratório, instalando o processamento de cópias coloridas até o formato $50 \times 60 \mathrm{~cm}$. Isso nos conferia autonomia com relação aos laboratórios externos, com a exceção das cópias em tamanhos maiores, apenas muito raramente necessárias. 
A maior parte das fotografias que produzíamos para aplicações comerciais, permitiam avaliação até certo ponto bastante racional, no entanto, era impressionante como pequenas alterações de filtragem e exposição produziam diferenças perceptíveis nos resultados, mas bastante sutis a ponto de ser difícil explicar porque, entre duas imagens tão parecidas, se julgava uma delas melhor do que a outra. A explicação racional deveria se encontrar nas questões de sintaxe apontadas por Crawford, mas certamente havia outros fatores bastante complexos em jogo.

O laboratório do estúdio tinha sido instalado apenas para atender à demanda interna, mas houve algumas ocasiões em que fizemos ampliações de negativos produzidos por outros fotógrafos. Nessas ocasiões pudemos conhecer a questão do relacionamento entre fotógrafo e laboratório, visto pelo outro lado. Talvez o mais interessante desses trabalhos tenha sido o das fotografias feitas no Amazonas por Antonio Carlos D'Ávila, que viriam a ser sua tese de doutorado na ECA. Recebemos os negativos já selecionados, juntamente com algumas cópias feitas em máquinas automáticas para servir como referência. A partir daí, começou um trabalho que se estendeu por mais de um mês, produzindo centenas de provas que procuravam obter as desejadas nuances de cor e brilho.

Nas reuniões de trabalho com o fotógrafo, examinando as provas, ficava muito claro que se estava fazendo um trabalho de prospecção da memória visual das cenas fotografadas e que pequenas variações nas cores ou densidades das provas não eram avaliadas apenas objetivamente, em termos do que seria a melhor cópia da foto.

Isso ocorria, mas esse julgamento formalmente racional se dava em cima de um outro mais profundo e sutil que procurava atender a um tipo de sintonia entre as recordações visuais e afetivas da experiência vivida, que se atualizava ali, na frente das diversas opções de cores e contrastes. 
Uma parte importante e significativa do processo estava ocorrendo nessa ocasião, muitos meses depois de as fotos terem sido feitas, e de terem sido revelados os filmes e preparadas as provas de serviço.

Ainda que estivéssemos trabalhando dentro das regras e limites determinados pelos modelos sintáticos, operava-se com outras variáveis que não se traduziam necessariamente por relações diretas de ótica ou energia luminosa. Tudo isso era percebido intuitivamente. A tentativa de chegar, na medida do possível, a uma melhor compreensão de como agem esses sutis mecanismos culturais, psíquicos e muitas vezes afetivos, na construção da significação das imagens fotográficas, está na origem deste trabalho.

Para isso vamos começar examinando o substrato técnico do processo fotográfico, aquilo que hoje na era da informática é comumente conhecido como "hardware" procurando mostrar como a interação do fotógrafo com cada um deles determina diferentes procedimentos na prática do processo. 
CAPITULO 2

Evolução dos Equipamentos 
A história da fotografia mostra que a evolução dos conhecimentos sobre a fotossensibilidade, por um lado, e os estudos envolvendo a câmara escura, por outro, se dão de forma mais ou menos paralela no tempo. Mas, enquanto a câmara escura era encarada como instrumento para pesquisa astronômica, as preparações fotossensíveis se destinavam à aplicações mágicas, medicinais ou até como pigmento para tingimento.

Os conhecimentos sobre a luz e a formação da imagem vão levar ao desenvolvimento da câmara escura cujos fundamentos parecem ter sido conhecidos ainda que de forma vaga, desde a antiguidade. Aristóteles menciona a formação de imagens, projetadas através de uma pequena abertura. As primeiras referências mais exatas sobre o aparelho são encontradas no texto "Sobre a Forma do Eclipse" do sábio árabe Ibn al Haitam (1039 D.C). Nesse texto ele observa que a imagem do sol, durante um eclipse, projetada através de um pequeno furo, apresenta a forma de uma foice, exceto no caso de eclipse total. Mas a imagem só tem essa forma se a abertura for muito pequena. Com o aumento do tamanho do furo a imagem tende a assumir a forma da abertura.

O conceito de "formato"

É importante observar que até aqui não estamos falando de "formato", mas apenas da imagem formada e de uma tendência de, com o aumento da abertura de entrada de luz, a imagem ir se dissolvendo na forma do orifício de entrada da luz. A imagem se forma a partir de um cone de luz e vai se esmaecendo à medida que o ângulo do cone vai se abrindo e se afastando do eixo determinado pela normal à superfície de formação da imagem.

Quando a câmara escura começa a encontrar aplicação, como instrumento auxiliar no desenho e pintura, a questão do "formato" da 
imagem surge naturalmente, sendo limitado, em princípio, apenas pelas dimensões da própria câmara escura. Normalmente esse formato é retangular e se situa dentro do cone de luz que forma a imagem. $\mathrm{O}$ caimento da intensidade luminosa é outro fator que limita as dimensões do formato.

Como podemos ver na imagem abaixo, a imagem se forma a partir de um cone de luz sendo que a forma retangular (ou quadrada, que é apenas um caso particular do retângulo), vem do formato do anteparo sobre o qual se forma a imagem, bastante conveniente devido à maior dificuldade para produzir telas com formatos arredondados.

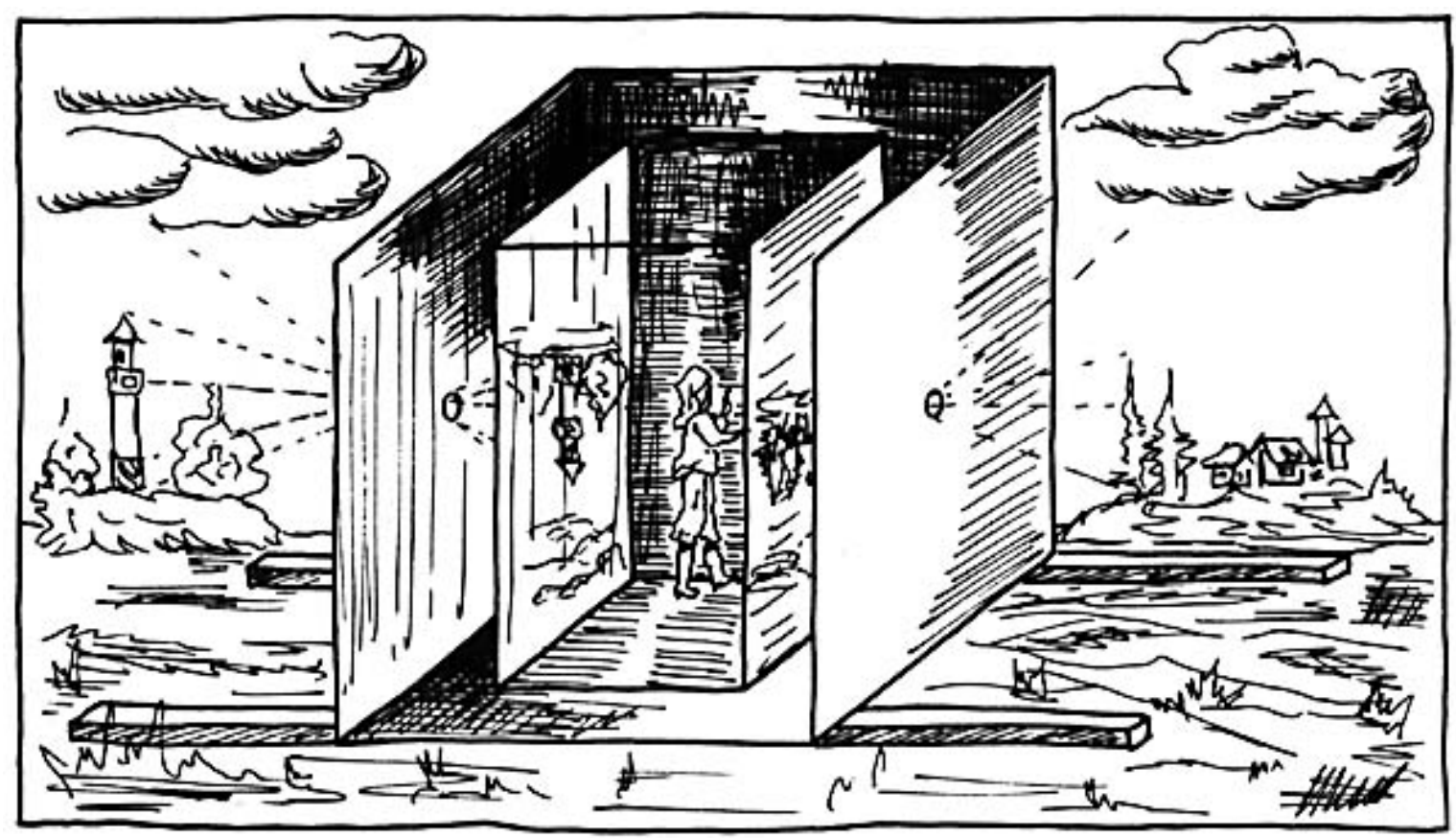

Desde já é importante que se destaque a idéia do "recorte" do cone de luz porque, posteriormente, ele definirá várias questões ligadas ao "enquadramento" da cena.

Essa idéia torna-se mais clara quando pensamos na diferença entre o modo como vemos as imagens formadas por uma luneta ou binóculo, com formato circular ou em figura de $\infty$ (infinito ou oito deitado), com 
bordas um tanto difusas e as imagens fotográficas em formato retangular com limites bem definidos.

Consolidado o uso da câmara escura como instrumento de apoio ao desenho e pintura, a busca pelo automatismo no registro da imagem formada produziu a convergência entre esses conhecimentos óticos e os conhecimentos químicos sobre fotossensibilidade, em um processo que durou cerca de duzentos anos, entre a segunda metade do século XVI e meados do século XIX.

Durante o tempo de desenvolvimento dos processos, quando os equipamentos eram construídos pelos próprios pioneiros, a questão do formato se determinava pela conveniência de cada um, adequada pelos recursos disponíveis e aplicação almejada. $\mathrm{O}$ uso de formatos maiores significando sempre dispêndio maior de matérias primas e tempo de trabalho, mas oferecendo, em contrapartida, registros mais detalhados.

Uma vez estabelecidos os procedimentos, imediatamente surge uma produção em escala artesanal que, pouco a pouco, evolui até atingir volume industrial. Como já vimos, a câmara escura já se encontra há muito desenvolvida quando as pesquisas sobre a automatização do registro ainda estão começando. Isso permite com que logo os pioneiros pudessem contar com câmaras produzidas por artesãos de ótica e mecânica de precisão, enquanto que as superfícies sensíveis de registro permaneceriam ainda por bom tempo no domínio da produção própria.

O conceito de formato se liga não apenas às dimensões físicas do quadro, largura e altura, mas também à relação entre essas duas dimensões que estabelece uma proporção. A orientação do quadro tem alguma importância nos equipamentos de filmes em rolo, nos quais a dimensão maior pode coincidir com o sentido lateral ou com o longitudinal do filme, o que pode fazer com que surjam diferenças entre a captação de 
imagens verticais ou horizontais, ou seja, nas orientações conhecidas como "retrato" ou "paisagem", respectivamente.

Nas imagens abaixo, podemos ver que o fotógrafo pioneiro utilizava um vasto conjunto de frascos e outros equipamentos típicos de laboratórios de química para produzir suas próprias superfícies sensíveis de registro, mas, a menos que ele resolvesse construir sua própria câmara ou encomendar um modelo especial, sob medida, a liberdade de escolha do formato já sofria as constrições de tamanho determinadas pelas dimensões dos diversos modelos de câmaras disponíveis no momento.

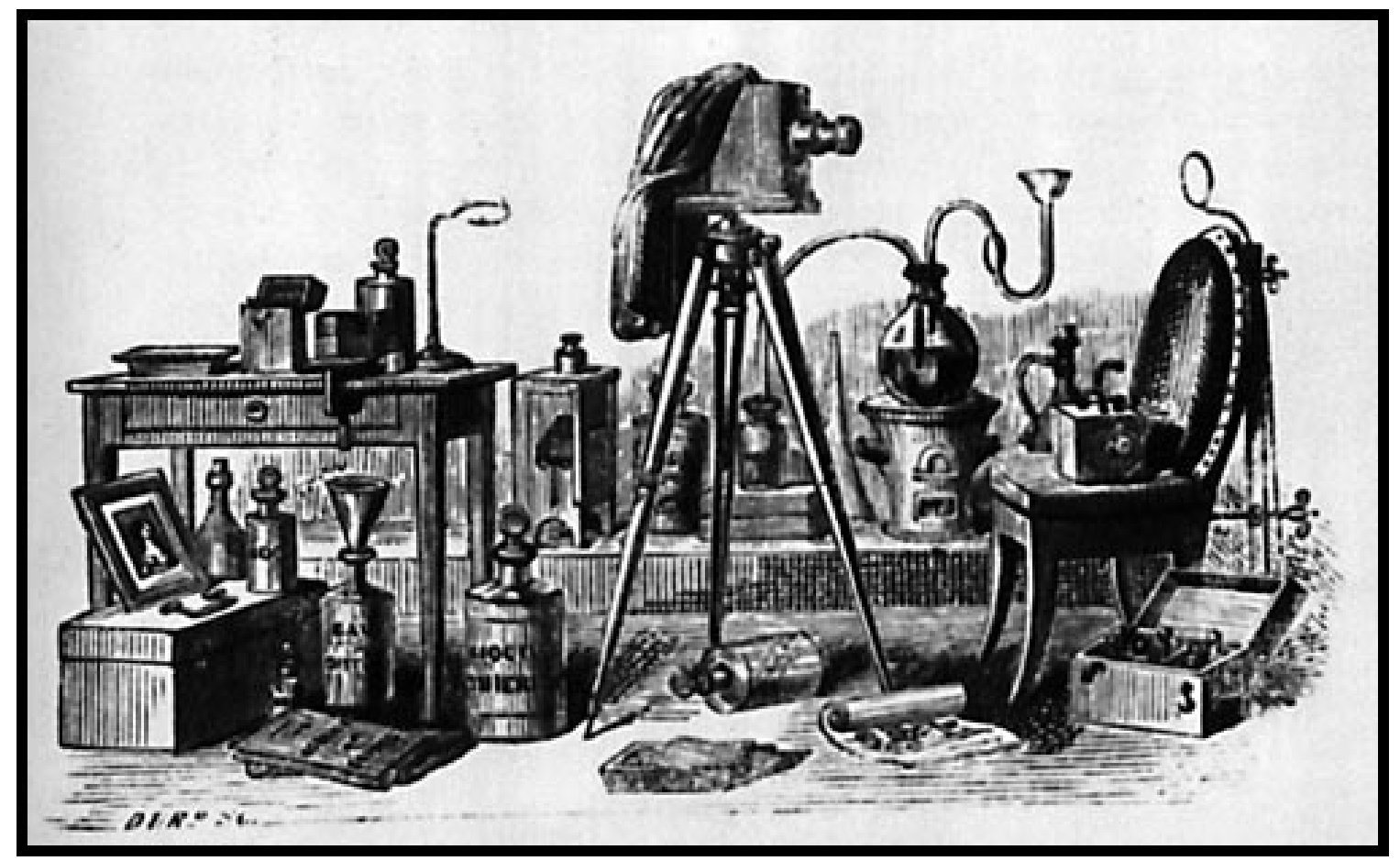




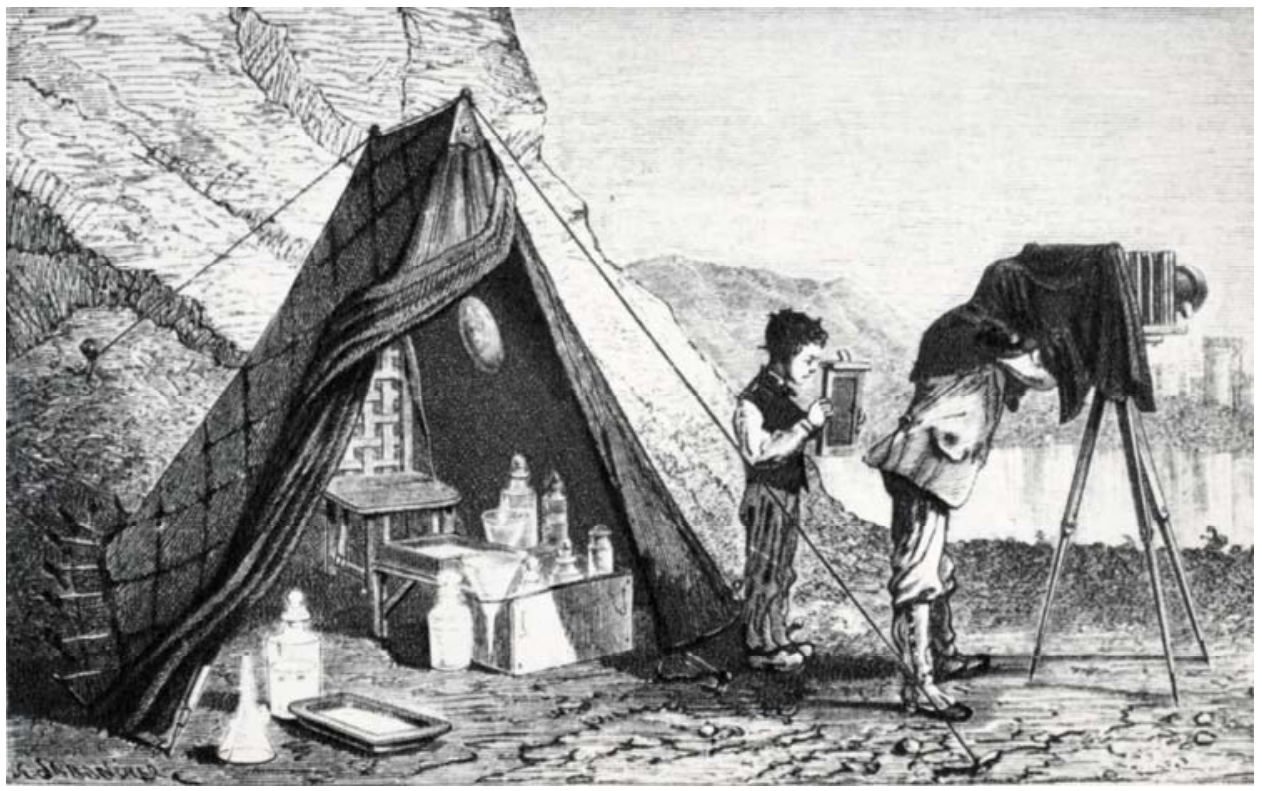

Da escala artesanal para a industrial

A imagem abaixo, que se considera o primeiro registro fotográfico, captada por Niépce em 1826, marcou o início de uma expansão na produção de imagens.

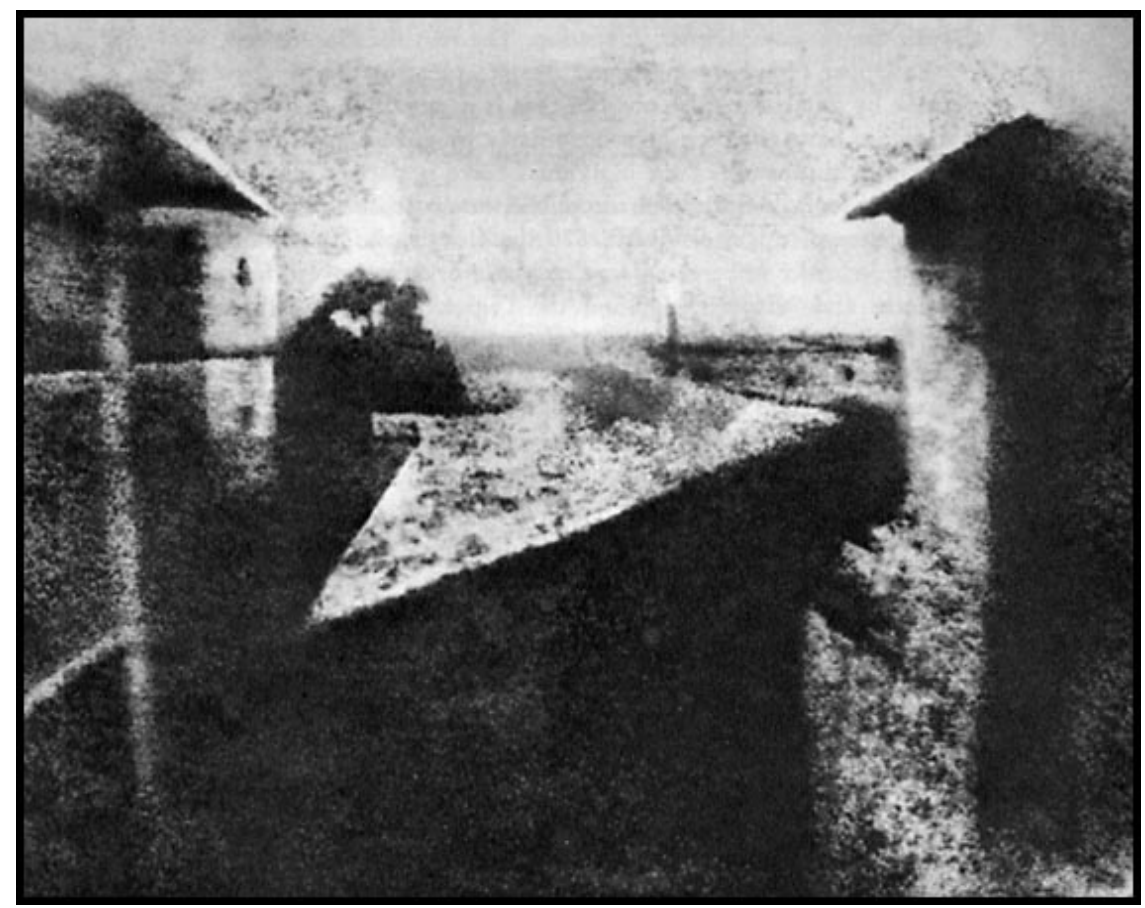


É possível se ter uma idéia da velocidade desse processo tomando como base que, na década de 1890, apenas 65 anos após essa primeira imagem, a maior fábrica de materiais fotográficos da Europa, em Dresden, produzia papéis para cópias a base de albumina em um processo que utilizava, como matéria prima, as claras de algo como 60.000 ovos por dia, ou cerca de 18 milhóes de unidades por ano.

Completado o ciclo de industrialização do processo fotográfico, a fotografia deixa de ser utilizada apenas por pequenos grupos de interessados e se populariza. Nas mãos de multidões de fotógrafos, a quase totalidade das imagens produzida por essas câmaras estava vinculada aos formatos oferecidos pelas indústrias, principalmente a Kodak com seu slogan "você aperta o botão, nós fazemos o resto". Mesmo ficando aberta a possibilidade de se produzir imagens em formatos personalizados, o fato é que, os formatos industriais dominam a fotografia desse ponto em diante.

Aumenta a variedade de modelos oferecidos pela indústria bem como a facilidade de operação do processo. A opção por um determinado equipamento, e seu formato, se faz buscando um balanço em que são considerados aspectos como custo, tamanho, peso, facilidade de uso, adequação à aplicação desejada e ainda a "qualidade" da imagem registrada.

Equipamentos que produzem imagens menores costumam ser de uso mais econômico, pois consomem menos filme e material para cópias, lembrando que nos referimos a uma época que ainda não havia visto a popularização das cópias ampliadas. A economia era compensada pela necessidade de se contentar com imagens bastante pequenas, mas trazia a vantagem da versatilidade de poder estar com um equipamento sempre à mão. 
Junto com a padronização industrial vem a necessidade de definir escalas de sensibilidade para estabelecer relação entre os materiais sensíveis, as condições de luz e os ajustes de obturador e diafragma.

\section{A orientação da imagem}

Para podermos compreender essa transformação entre o uso da câmara escura e a operação das câmaras fotográficas, precisamos analisar algumas etapas importantes desse processo que foram determinando alterações fundamentais no modo como se dava a operação de captação e produção das imagens.

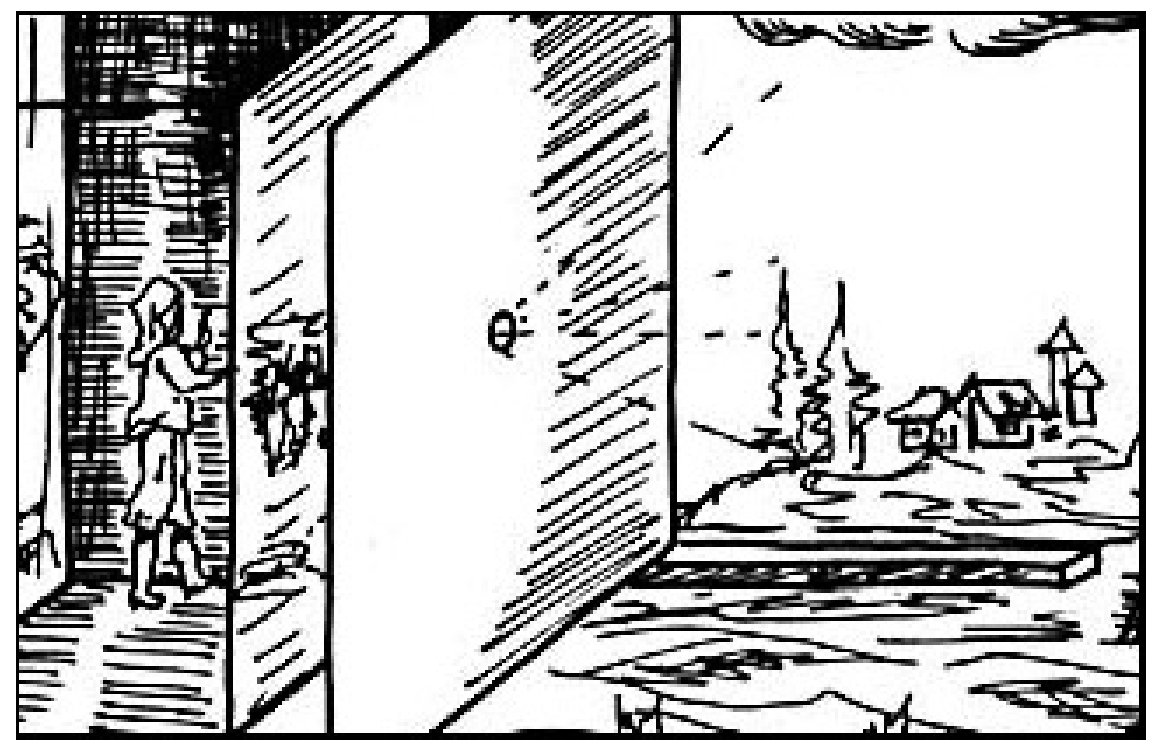

A figura acima é um detalhe da imagem do pintor dentro da câmara escura, mostrada na pág. X. Podemos observar que ele visualiza a imagem por transparência e não por reflexão, ou seja ele não fica entre o furo e o anteparo, mas atrás da superfície onde se forma a imagem. Essa posição do observador é importante não apenas para evitar que ele obstrua a formação da imagem ao bloquear os raios de luz, mas também 
porque é a posição em que a imagem observada está com orientação lateral correta.

Para corrigir a inversão produzida pelo furo estenopéico ou pela objetiva, basta girar em $180^{\circ}$ a superfície do desenho ou foto, mantida a posição do plano, permanecendo a imagem na mesma face do suporte. A correção da inversão lateral exige a rotação do plano, o que modifica o lado do suporte por onde se deve observar a imagem.

Os primeiros registros fotográficos, sem o uso da câmara escura, como os obtidos por Talbot em 1840 na imagem abaixo, expondo à luz superfícies sensíveis sobre as quais eram depositados objetos com alguma transparência, justamente por essa disposição, apresentam orientação lateral correta.

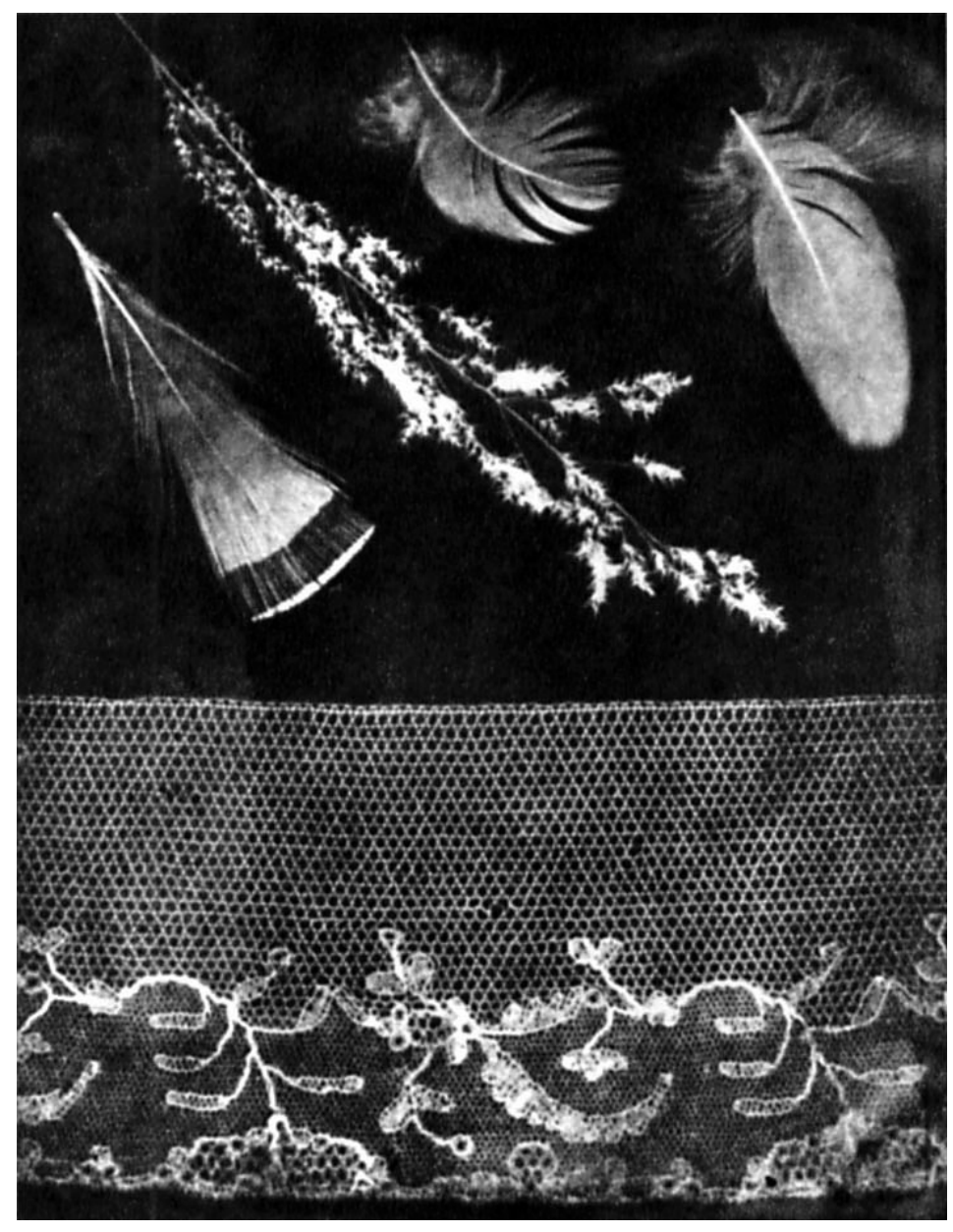


No entanto, isso não ocorre com a famosa imagem de 1826, pois Niepce usou uma superfície opaca para captar a imagem, e parece razoável supor que vista a partir da janela de seu quarto fosse mais próxima da imagem abaixo, à direita.

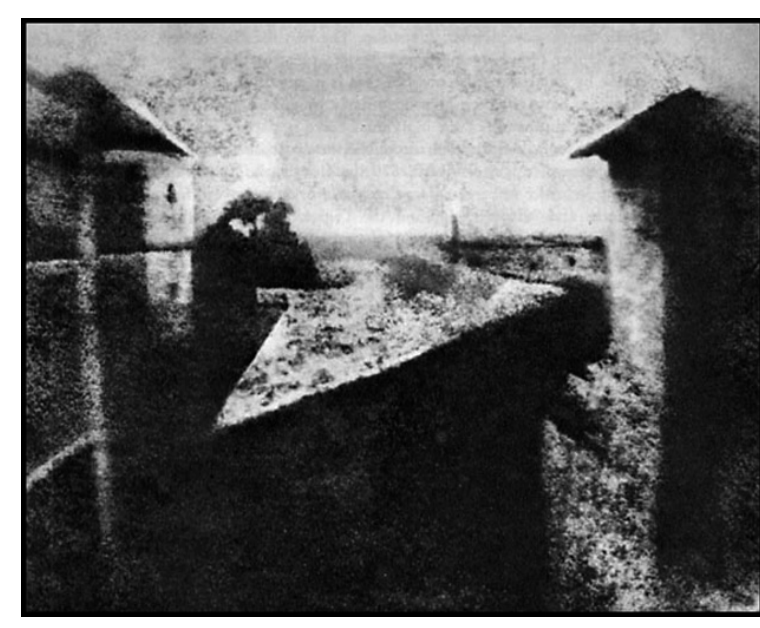

Orientação usual

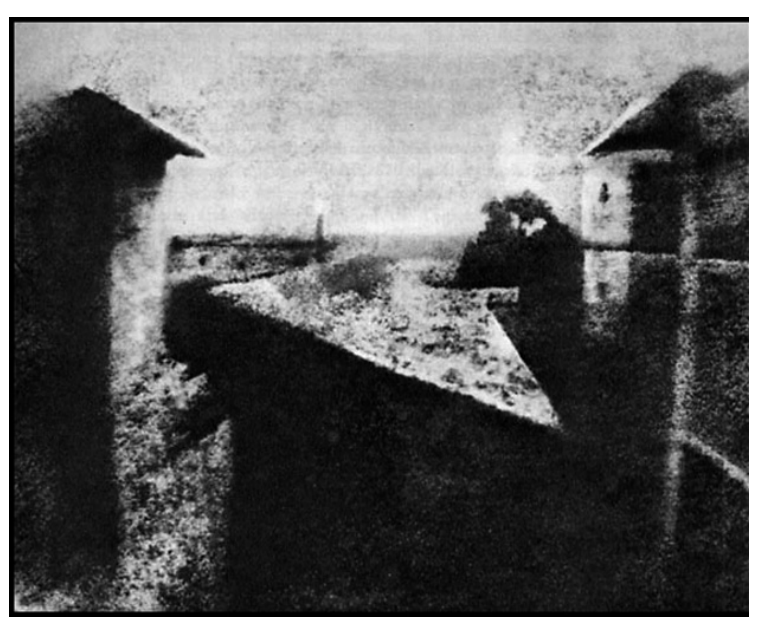

Invertida lateralmente

As imagens produzidas sobre superfícies metálicas como os Daguerreótipos e Tinótipos apresentam também orientação lateral invertida.

Durante as fases iniciais do desenvolvimento do processo fotográfico, o objetivo era produzir um registro único da imagem. Mais tarde se percebe a versatilidade de produzir um registro matriz, a partir do qual se pudesse extrair qualquer quantidade de cópias.

Esse modelo de produção em duas etapas - geração de matriz e extração de cópias - se mostra ainda muito adequado para resolver a questão da inversão tonal nas imagens produzidas pelos diversos sistemas, em que a variação na intensidade luminosa se traduz por variação proporcional no depósito sobre a superfície, gerando imagens que se convencionou chamar de "negativas". 
Os daguerreótipos e tinótipos, por exemplo, eram montados em pequenos estojos com uma tampa articulada forrada em material escuro e fosco. A observação das imagens se fazia ajustando a abertura da tampa e o ângulo de observação de forma que o plano da superfície metálica produzisse reflexo especular da tampa escura, gerando o nível "escuro" da imagem nos locais onde não havia formação de depósito. Nos pontos da superfície onde havia depósito, o reflexo difuso da luz, estabelecia tons claros em relação proporcional à quantidade de depósito formado, criando assim uma pseudo "positivação" da imagem.

É importante observar que, indo além da engenhosidade demonstrada por esses pioneiros, fica evidente o fato de que o processo de produção das imagens fotográficas já exigia operações posteriores à captação e formação da imagem em si, para se chegar ao produto final acabado.

Evolução dos suportes

As etapas seguintes na evolução dos processos fotográficos procuram obter imagens sobre suportes transparentes para permitir extrair cópias com facilidade e na orientação lateral correta. Tenta-se o uso de superfícies de papel. Para melhorar a transparência, impregnava-se o papel, durante a fase de copiagem, com alguma substância oleosa. O vidro mostrou-se, contudo muito mais adequado assim que se conseguiu resolveu o problema de fixação da camada sensível à superfície do suporte usando, como mordentes, albumina e posteriormente gelatina.

Entretanto, o vidro apresentava alguns problemas como o peso e a fragilidade, aspectos em que papel se mostrava superior. A busca por uma solução que unisse as vantagens dos dois materiais, evitando simultaneamente seus inconvenientes acabou por levar aos filmes 
plásticos que acabaram se tornando suporte universal até hoje, para emulsões fotográficas.

As características de flexibilidade dos filmes plásticos dependem, além da composição do material, de sua espessura, cujo aumento leva a uma maior rigidez. Formatos maiores, como as chapas empregadas em equipamentos avançados para uso profissional, exigem espessuras que ficam pouco abaixo de um milímetro.

Por outro lado, o uso de plásticos finos oferece flexibilidade suficiente para que o filme seja enrolado e isso permitiu criar filmes em rolos para registrar imagens sucessivas ao longo do seu comprimento.

Filmes em rolos

A invenção do filme em rolo estabelece um marco importante, pois ao mesmo tempo em que permite a popularização do uso do sistema fotográfico, vai exigir completa mudança nos procedimentos de captação e produção das imagens.

Para compreender isso precisamos voltar brevemente aos primórdios dos registros usando câmara escura, onde o operador visualizava a imagem formada sobre um anteparo ajustando a posição do dispositivo até obter a imagem desejada. Estabelecido o "enquadramento", a entrada de luz era fechada e se colocava a superfície sensível exatamente no lugar em que a imagem se formava, permitindo em seguida que a luz atingisse a superfície para registrar a imagem.

Por incrível que possa parecer, esse ainda é exatamente o mesmo procedimento usado até hoje nos equipamentos avançados de uso profissional que usam chapas avulsas que são montadas em suportes 
essencialmente semelhantes ao que vemos abaixo, no detalhe da imagem da pág 39 .

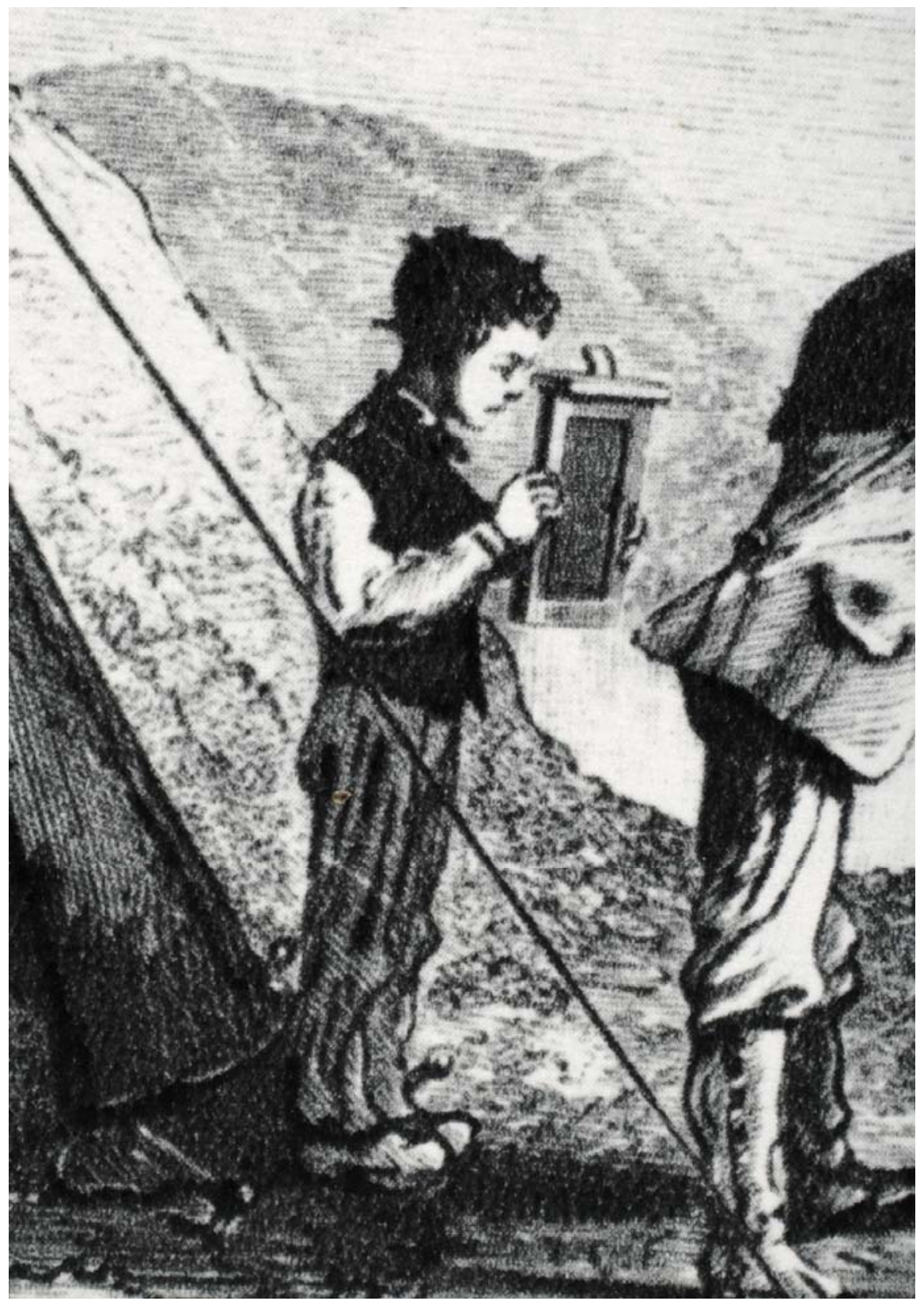




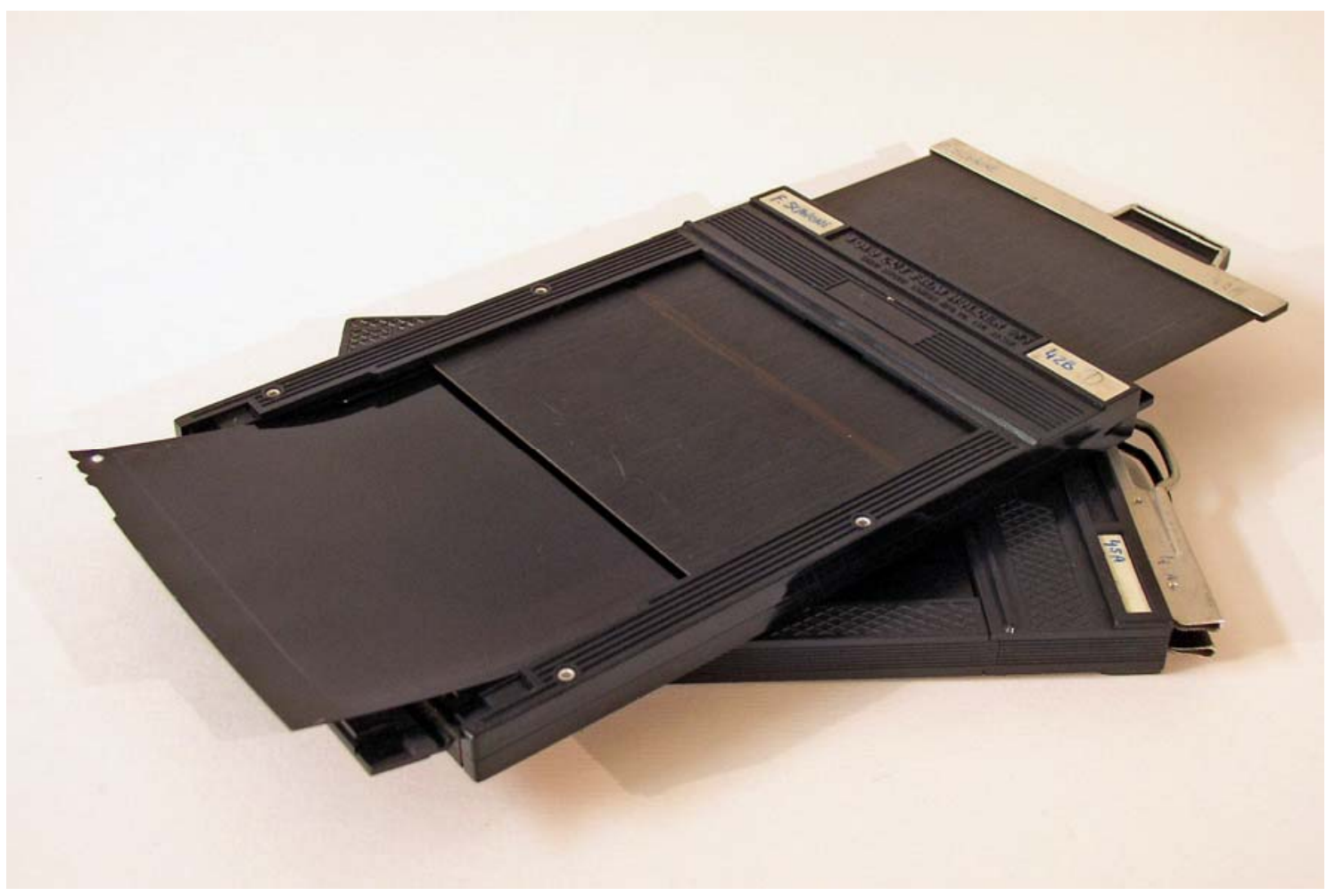

Chassi $4 \mathrm{x} 5$

Nos equipamentos de chapas, desde o século XIX até hoje, se estabelece a composição da imagem analisando uma superfície translúcida (o vidro "despolido"), que ocupa o exato lugar em que a chapa estará no momento do registro. Esse é um processo quase sempre lento e nele se procura estabelecer com cuidado todos os parâmetros de cada imagem formada que constitui, em si, um evento completo.

Seja qual for o equipamento é inevitável usar dispositivos para controlar a luz que chega até a chapa. O controle da intensidade da luz se faz reduzindo o diâmetro útil da lente. Isso pode ser feito usando desde uma lâmina opaca com furos de diversos diâmetros até um completo dispositivo, como mostrado na foto abaixo, composto por finas lâminas curvas metálicas que permitem obter uma abertura circular com variação contínua no diâmetro.

Isso se faz por meio de obturadores e diafragmas. Esses dispositivos devem estar situados próximos à lente. Na realidade, ficam quase dentro das objetivas, entre os elementos óticos. 


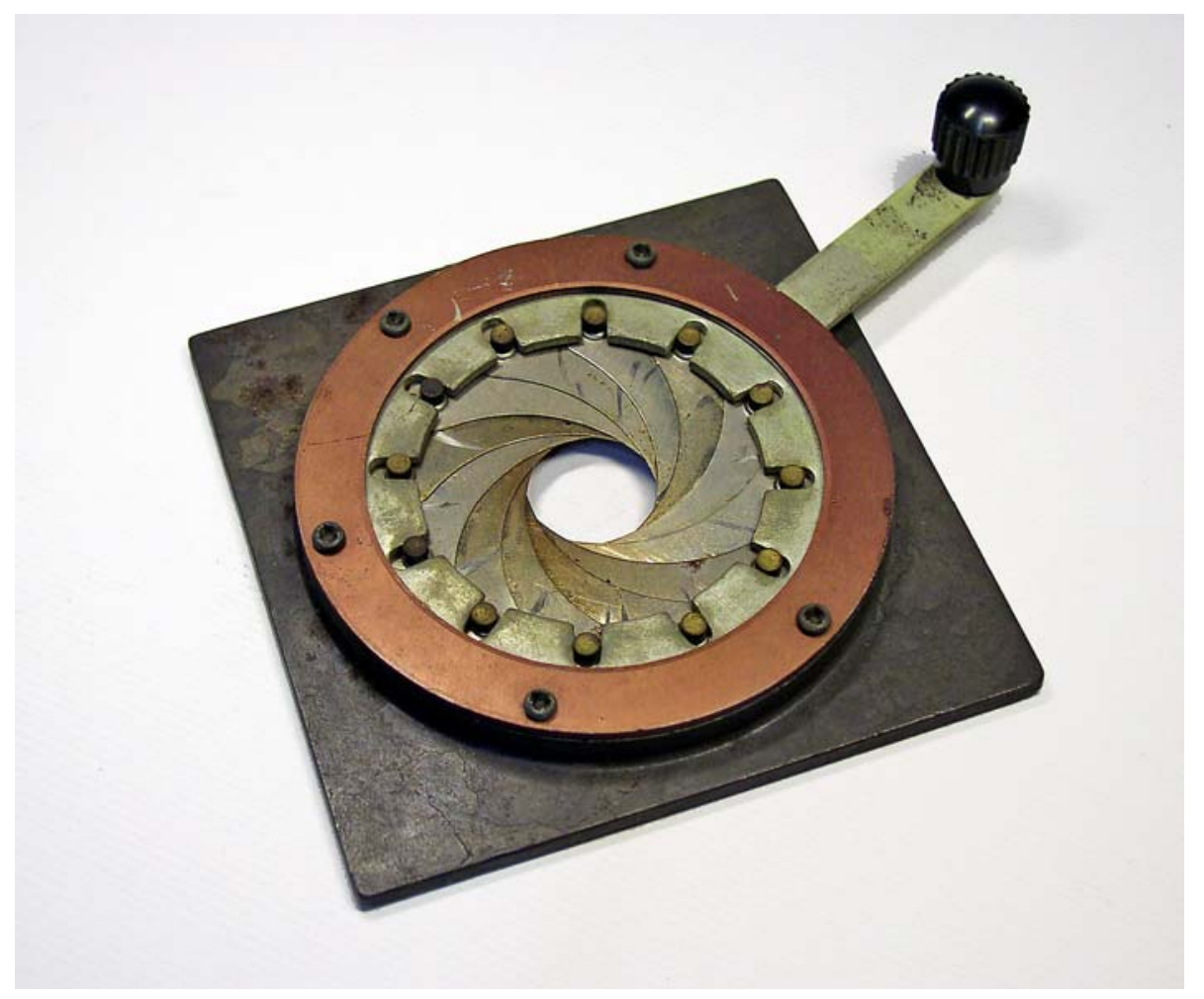

Diafragma

O obturador pode usar dispositivo semelhante ao do diafragma, mas com desenho diferente das lâminas. Aqui não importa a variação contínua na abertura, mas sim alterar rapidamente entre os estados "aberto" e "fechado", bem como dispor de um dispositivo de relojoaria que permita controlar o tempo de abertura. Na maioria das câmaras fica dentro da objetiva, próximo ao diafragma. No caso das câmaras que permitem a troca de objetivas seria preciso ter um obturador em cada uma delas, além de algum meio de proteger o filme durante as trocas de lentes. Uma solução comumente adotada é usar um obturador que, ao invés de ficar junto da objetiva, se situa no fundo da câmara, logo à frente do filme. Com isso, além da proteção do filme se evita a necessidade de se ter um mecanismo em cada objetiva, reduzindo custos. Esses dispositivos são conhecidos como obturadores de cortina, ou de plano focal e em determinadas circunstâncias, como veremos mais adiante, podem apresentar limitações ou mesmo influir no registro das imagens. 
Os equipamentos desenvolvidos para usar filmes em rolos, logo permitiram obter com facilidade muitas imagens em sucessão, sendo exemplo clássico a câmara desenvolvida pela Kodak que inicia o rápido processo de universalização do uso do meio fotográfico.

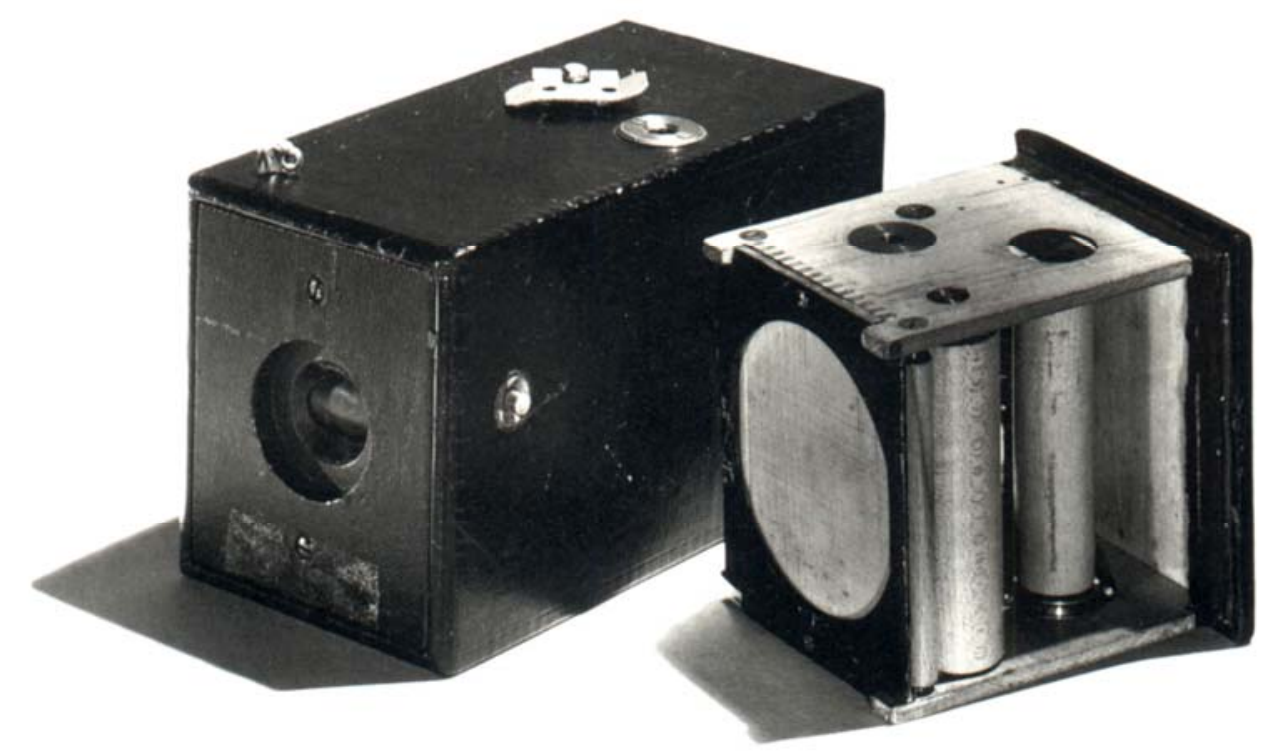

Essa primeira câmara Kodak apresenta algumas características muito particulares como o formato redondo nas imagens registradas e a ausência de qualquer dispositivo auxiliar de enquadramento. Versões subseqüentes logo adotaram alguma forma de visor para facilitar o enquadramento bem como se afastam da imagem circular, retornando aos formatos retangulares.

O uso do filme em rolo permitiu simplificar muito a operação de registro das imagens, eliminando o domínio técnico exigido para as complexas operações de manipulação e processamento das emulsões. O mote comercial de George Eastman, "você clica, nós fazemos o resto", não seria possível sem o filme que permitia registrar cem imagens antes de enviar a câmara de volta ao laboratório. 
Ainda que rigorosamente não se possa dizer o filme em rolo exige sempre a ocupação permanente, do plano de formação da imagem, visto que foram desenvolvidos dispositivos que, montados sobre câmaras originalmente projetadas para chapas, permitem o uso de filmes em rolo, na prática isso ocorre na quase totalidade dos casos.

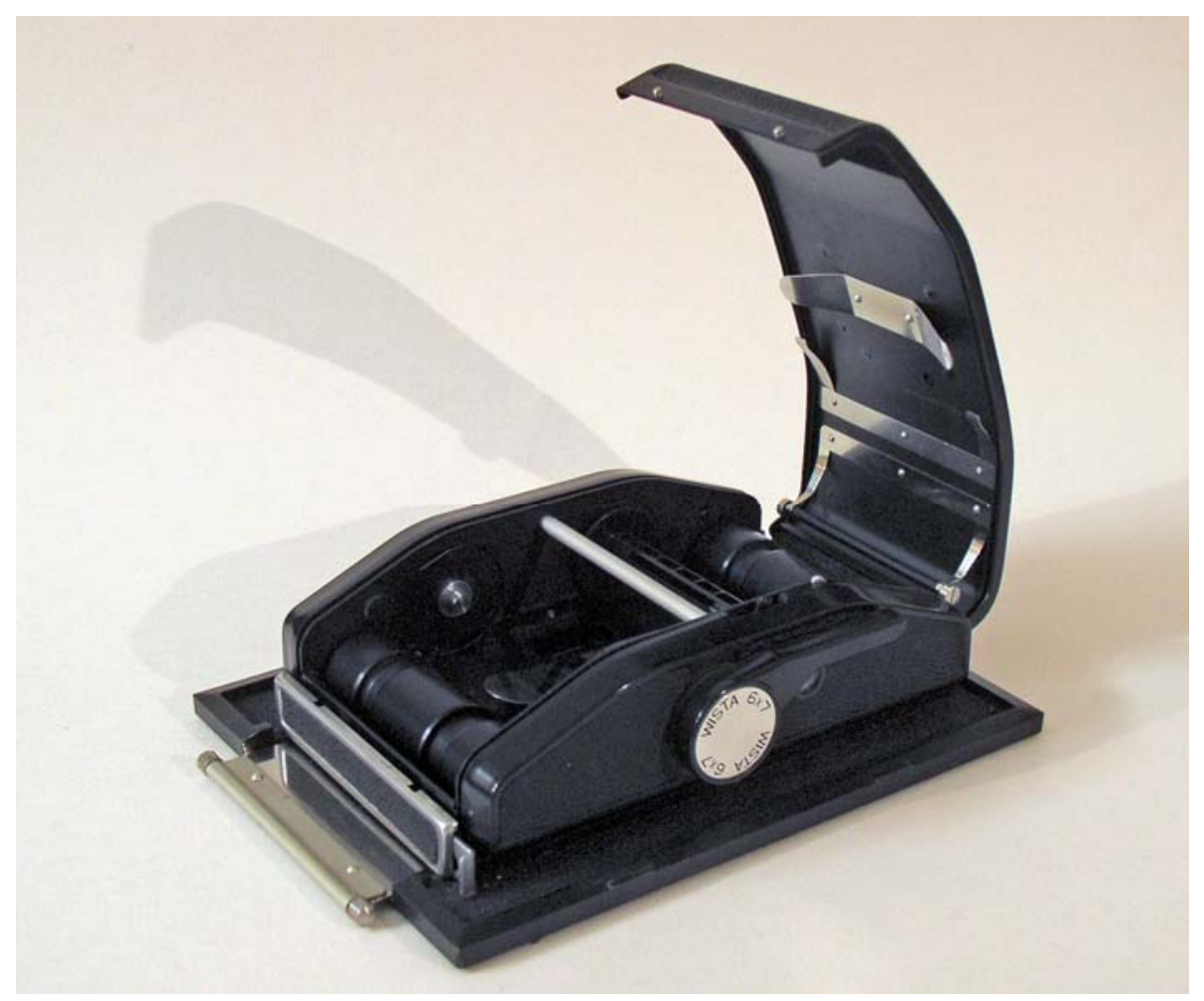

Chassi $6 x 7$ para câmara de chapas

Estando então o plano focal, ocupado pelo filme, não é mais possível visualizar a composição da imagem nesse local, sendo ainda preciso proteger da luz a área de formação da imagem para evitar a velatura da superfície sensível.

O filme em rolo vai impor algumas exigências como o surgimento dos sistemas de visor e o desenvolvimento de mecanismos de transporte para fazer o avanço do rolo de filme dentro da câmara. 
$\mathrm{O}$ visor

Para auxiliar o fotógrafo na tarefa de determinar o correto enquadramento da área a ser registrada foram surgindo muitas soluções técnicas, desde meras molduras de arame, colocadas na parte dianteira da câmara até sofisticados sistemas óticos que desviam a luz que entra pela objetiva fazendo com que a imagem se forme sobre um anteparo translúcido situado com precisão, em local oticamente equivalente ao plano de formação da imagem, onde se encontra o filme.

Os visores diretos, como o mostrado na imagem abaixo, funcionam razoavelmente bem desde que o assunto não esteja muito próximo e o enquadramento se faz com câmara próxima ao olho.

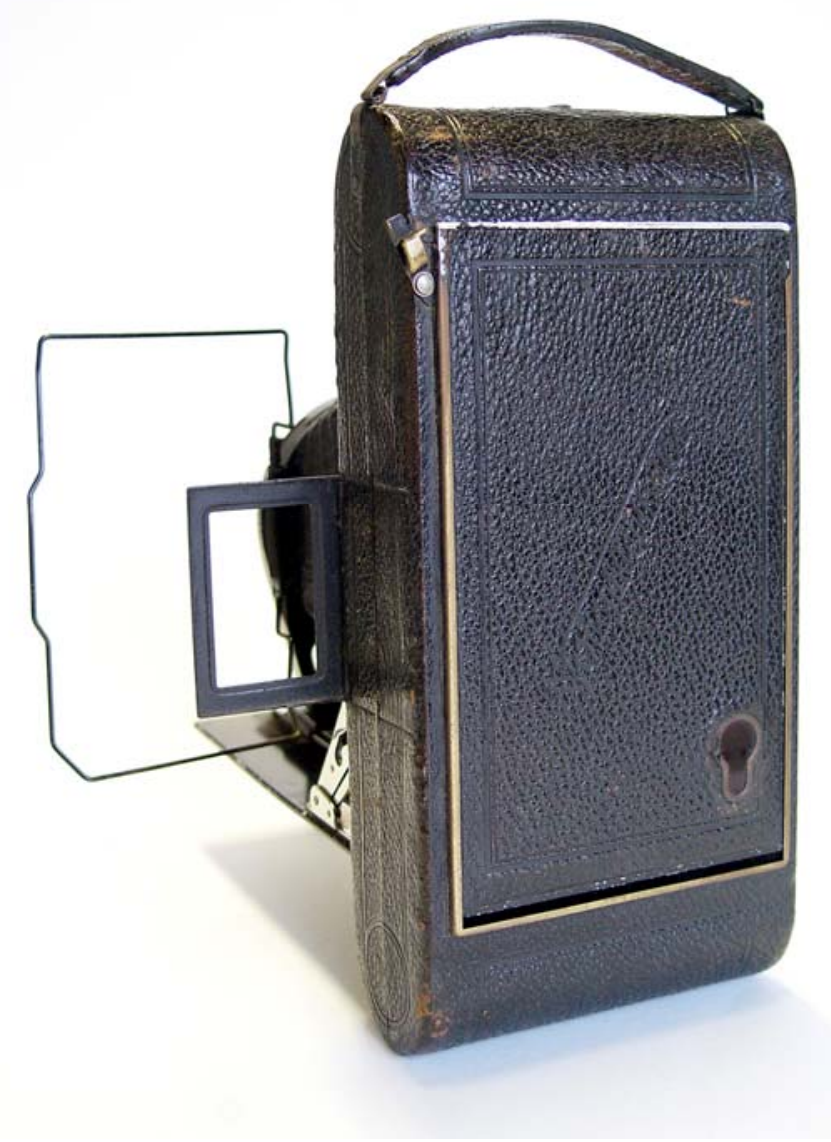


Outra solução empregada em muitas câmaras simples é um visor que utiliza duas lentes e um pequeno espelho. A imagem é enquadrada com a câmara no nível da cintura.

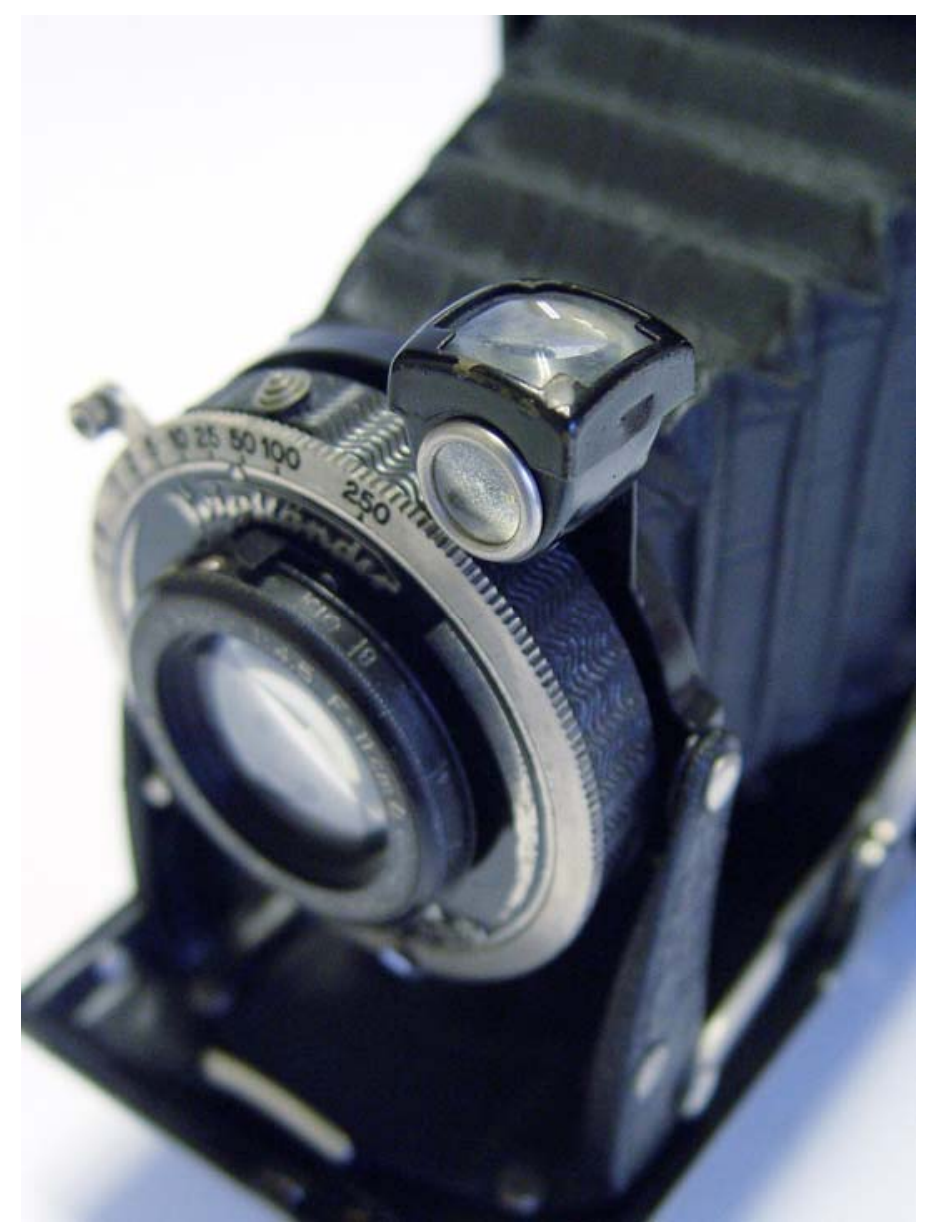

Da mesma forma que acontece com o visor direto, o tipo com dois visores não oferece condição de avaliar a focalização da cena enquadrada. Como o eixo do visor não coincide com o eixo ótico da objetiva, a janela muda de posição quando a câmara é girada para alterar a orientação do formato entre horizontal (paisagem) ou vertical (retrato). Essa característica força o uso de uma montagem rotativa do visor como na imagem acima ou, quando isso não é possível, a instalação de dois visores iguais, um para cada orientação, voltados para faces diferentes da câmara. 


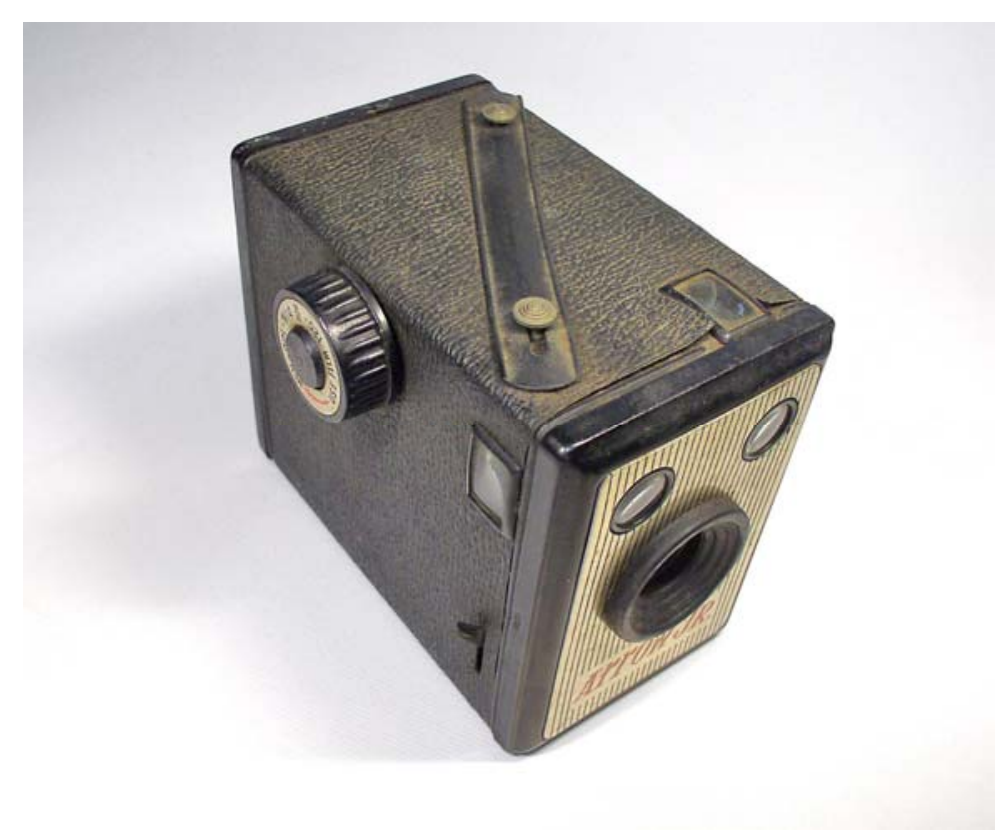

Câmara box com os dois visores.

Muitas câmaras tinham os dois tipos de visor, permitindo fotografar tanto com a câmara encostada no olho como no nível da cintura.Olhando por esses visores, o que se via era completamente diferente da natureza das imagens formadas pela própria objetiva sobre o vidro despolido.

A bem da verdade, os quadros de arame sequer formavam uma imagem, mas mesmo nos visores em que isso ocorria, elas estavam sempre nítidas, independente do ajuste da objetiva e assim não permitiam avaliar a focalização da imagem que seria registrada. Sua função era apenas mostrar qual parte da cena que iria aparecer na foto e não a forma como ela iria aparecer. Para focalizar a imagem era preciso avaliar a distância do assunto e ajustar de forma apropriada a posição da objetiva com relação ao plano do filme usando para isso uma escala calibrada de focalização. Assim, se era possível garantir que objetos situados a determinada distância estariam focalizados, não se podia, entretanto, avaliar, como no vidro despolido, a forma como seria a transição entre essas áreas em foco e outras que sairiam fora de foco. 
Procurando recuperar a imagem formada pela objetiva sobre um vidro despolido, com todas as suas características, surgem os visores reflex. Há duas soluções básicas:

1 - usar a própria objetiva formadora da imagem e instalar um espelho basculante atrás dela, desviando a luz para um vidro despolido. No momento da exposição o espelho se desloca para permitir que a luz atinja a superfície do filme. Esse sistema permite avaliação rigorosa da imagem formada. Em alguns equipamentos como as antigas câmaras Exacta e até hoje as câmaras Hasselblad, após o acionamento do obturador, o visor não reabre quando é concluindo um ciclo de captação, sendo preciso avançar o filme para poder voltar a enxergar a imagem. Mas esses casos constituem exceções.

2 - uma variante da solução anterior, usa uma objetiva mais simples, com distância focal igual à da lente principal e montada no mesmo plano desta, em posição bastante próxima, para formar uma imagem essencialmente semelhante à que será registrada no filme. Isso se por um lado duplica o sistema ótico, por outro simplifica drasticamente a parte mecânica pois se pode manter fixo o espelho, já que agora não é mais preciso afastá-lo do caminho durante a exposição. O exemplo clássico dessa categoria é a Rolleiflex. 


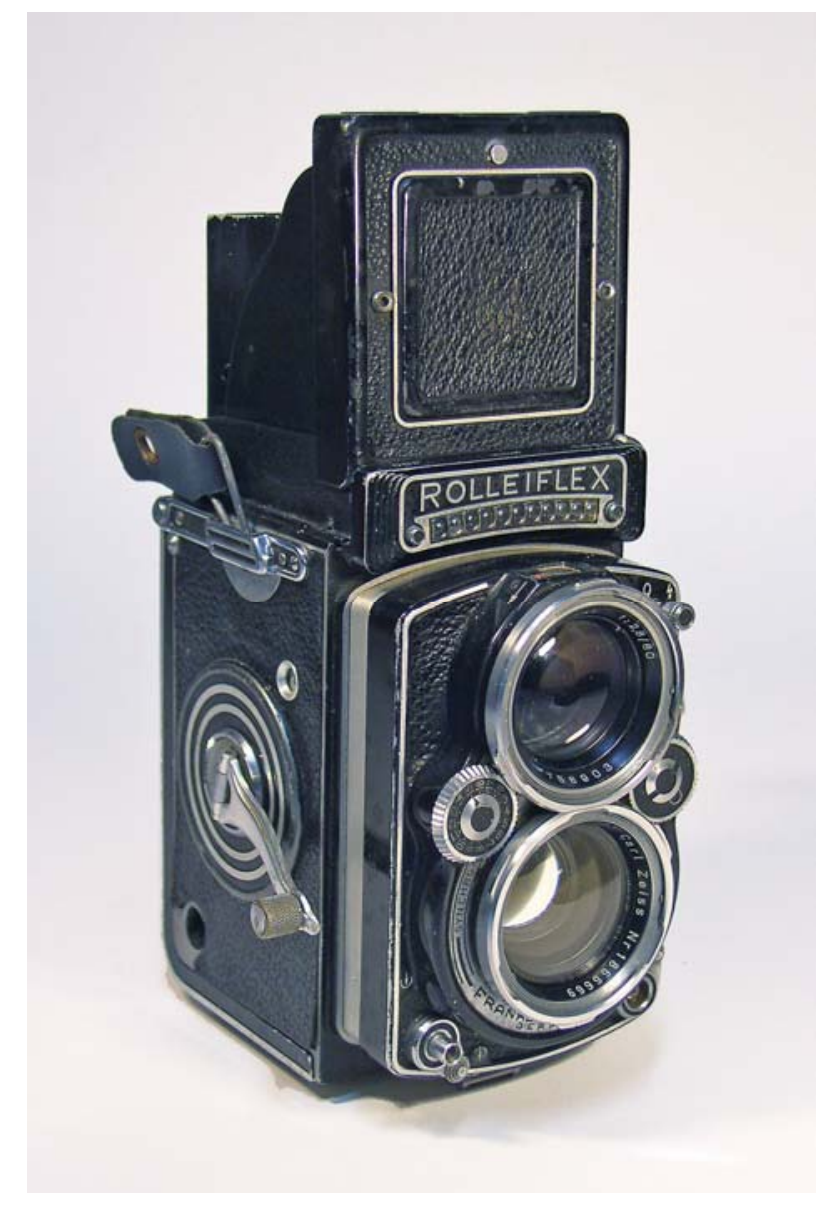

Na câmara de chapas existe uma divisão muito clara entre o tempo de composição e enquadramento e o tempo de registro. A montagem permanente do filme no local de registro muda isso de forma radical. Como não é mais preciso bloquear a entrada de luz e substituir o vidro despolido pelo chassi com a chapa, a passagem do tempo de composição para o tempo de registro pode ser instantânea.

Como regra geral, a imagem não desaparece do visor, ou quando isso acontece é durante apenas um pequeno intervalo de tempo, sendo possível, a retomada de um novo tempo de enquadramento-composição assim que concluída a operação de registro. 


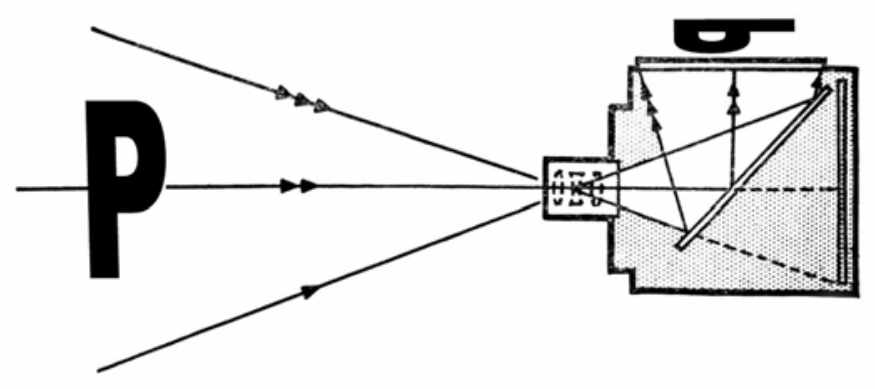

Nas câmaras com visores reflex em que o enquadramento se faz olhando por cima, a imagem no visor se apresenta invertida lateralmente, como se observa na imagem acima. Isso acontece tanto nas câmaras de uma como nas de duas objetivas e pode influenciar no enquadramento das imagens, como veremos mais adiante.

Outro problema que ocorre nas câmaras em que o enquadramento se faz olhando pela parte sua superior é a dificuldade que surge para mudar a orientação do enquadramento, entre horizontal e vertical. Quando se gira o corpo da câmara, muda a posição da face do aparelho em que se situa a janela do visor e é preciso então olhar a cena por um dos lados da câmara o que, sendo já bastante desconfortável, se agrava ainda mais devido à inversão da imagem citada acima.

Os visores reflex formam imagens no tamanho real do negativo, mas isso exige soluções construtivas, mais volumosas e de maior custo, que tornam inviável a duplicação do sistema ou mesmo o uso de algum dispositivo giratório, como se fazia nos visores pequenos que vimos anteriormente.

Se girar a câmara para fazer uma foto em orientação vertical criava uma dificuldade com o sistema de visor, talvez houvesse alguma forma de resolver isso sem ter que girar a câmara. Surge então a idéia de usar um formato quadrado de negativo. Linhas gravadas no visor serviam como orientação para que fotógrafo fizesse enquadramentos tanto verticais 
como horizontais com a câmara sempre na mesma posição, sem necessidade de girá-la. Posteriormente, durante a fase de copiagem bastava usar apenas a área desejada, descartando, conforme o caso as faixas laterais ou superior e inferior.

O visor reflex devolveu ao fotógrafo a possibilidade de fazer o enquadramento e a focalização usando a própria imagem que seria registrada ou pelo menos uma imagem praticamente semelhante. Contudo, se a imagem na câmara escura aparecia invertida no sentido vertical, nas câmaras reflex essa inversão era lateral.

Era desejável obter uma imagem real, como no visor reflex, mas alinhada com o eixo ótico e com a orientação correta como aquela do singelo visor de quadro de arame. A solução encontrada foi utilizar um prisma de 5 faces, como na imagem abaixo.

O pentaprisma endireita a imagem e leva o visor para o nível do olho. Isso torna muito realista a identidade da objetiva com o olho do fotógrafo.

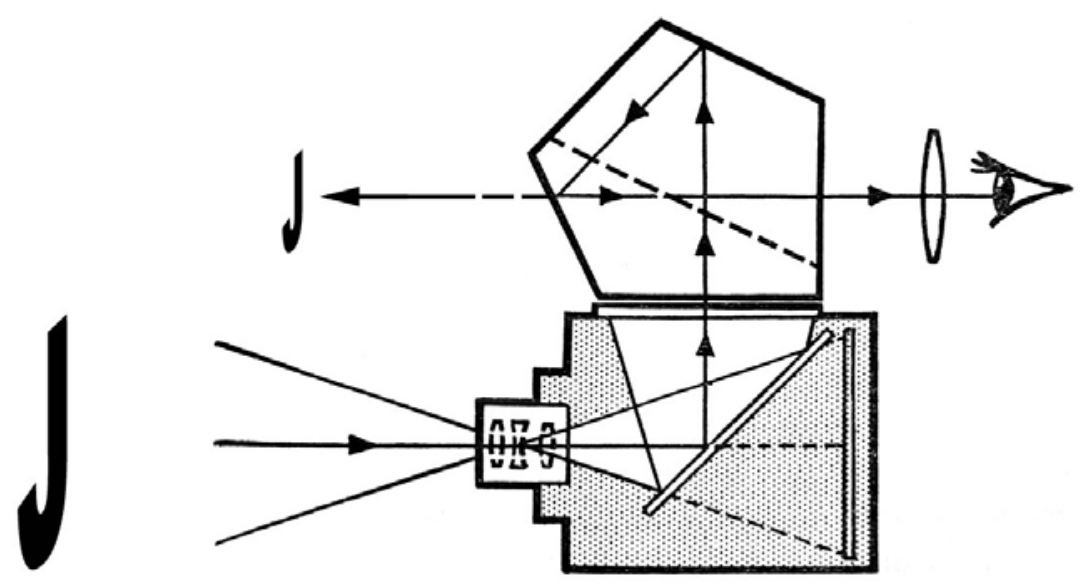


A possibilidade de operar de forma continuada, em ciclos sucessivos de enquadramento-composição e captação-registro depende, contudo de efetuar o transporte do rolo de filme, fazendo com que um pedaço ainda não exposto à luz seja posicionado no local correto.

O que nos leva a um outro problema que surge junto com os filmes em rolo, que é a necessidade de movimentar com precisão o filme plástico dentro da máquina, ao abrigo de toda luz.

Os mecanismos de transporte

Enrolado sobre um carretel, o filme forma uma espiral em que a cada volta, com o aumento do diâmetro, a camada vai tendo comprimento maior. Isso faz com que um deslocamento angular constante do carretel, que seria uma solução bastante simples, não possa ser utilizado, pois os intervalos entre fotogramas iriam se tornando progressivamente maiores, gerando grande desperdício de película.

A solução mais simples que se encontrou foi enrolar, junto com o filme plástico, uma fita de papel opaco que cumpre dupla função:

1 - protege da luz a parte posterior do filme 2 - a parte dorsal dessa fita recebe marcações com a posição correta de cada fotograma sobre o filme. 


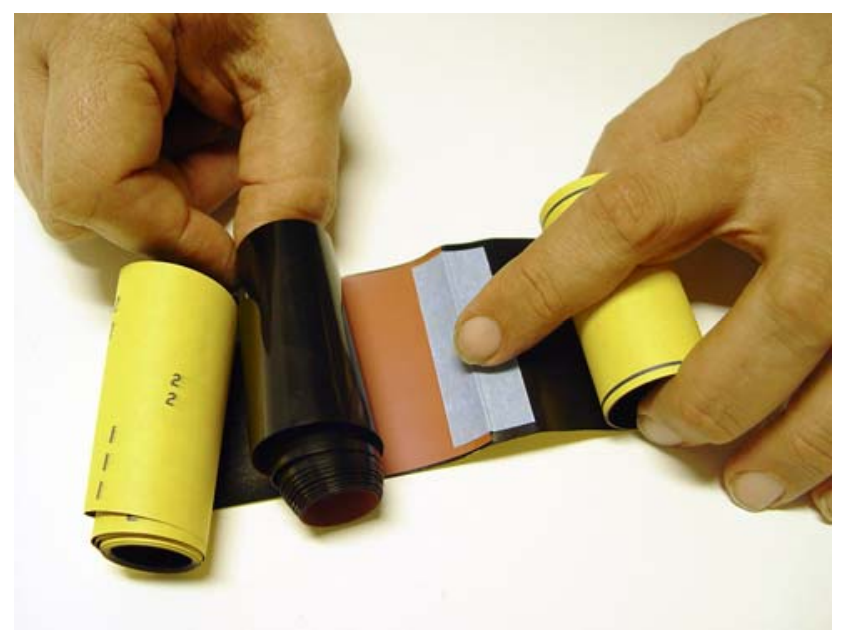

Com o filme protegido pelo papel opaco, uma pequena abertura no dorso da máquina permite visualizar as marcações sobre a fita de papel e fazer o transporte manual do filme até a posição correta. A largura do filme é usada para várias séries de marcações adequadas para diversos formatos de fotograma usando como base a largura do filme.

O procedimento típico consiste em, concluída a operação de registro de um fotograma, abrir a janela de espia e avançar o filme até o número seguinte, girando um botão ou manivela. Essa operação deve ser cuidadosa pois caso a marca seja ultrapassada, o equipamento não oferece opção de voltar o filme para trás.

Equipamentos mais sofisticados usam meios automatizados (ou semi) para controlar o transporte do filme. Esses dispositivos de transporte se apóiam em algumas soluções mecânicas básicas:

1 - Usar um sensor, na forma de rolete ou alavanca para compensar o movimento angular do carretel a partir da determinação do diâmetro da espiral de filme sobre o mesmo. Essa solução foi utilizada, por exemplo, nas câmaras Rolleiflex e Hasselblad. 
2 - Usar um sensor de movimento linear, em geral de forma cilíndrica, em contato com o filme que bloqueia o mecanismo de transporte quando tiver atingido o deslocamento adequado da película. Nesta solução o carretel recolhedor possui um mecanismo de embreagem que desliza evitando esforço excessivo sobre o filme quando o sensor determina o ponto de parada.

É interessante ainda notar que esta solução é a usual nos filmes de 35 $\mathrm{mm}$ de largura. Voltaremos a esse ponto ao discutir esse formato, cuja importância é fundamental na fotografia do século XX.

Formatos de filmes em rolo.

Os filmes em rolo foram produzidos em muitos formatos. Alguns bastante grandes, como o utilizado na câmara mostrada abaixo que tinha fundo removível permitindo operação alternativa com chapas ou filmes em rolos.

Os formatos maiores não se mostravam muito práticos pois o extenso comprimento de filme usado por cada imagem limitava muito a quantidade de fotos por filme, além de a operação de transporte ser demorada. Os formatos pequenos, ao contrário, ofereciam maior autonomia e rapidez no transporte, sendo sua limitação a qualidade da imagem que permitiam obter. Os aperfeiçoamentos, tanto dos sistemas óticos das objetivas, quanto das emulsões que trouxeram simultaneamente aumento da sensibilidade e diminuição da granulação foram tornando os formatos menores cada vez mais interessantes e colocando em desuso os rolos com larguras maiores. 
Até hoje, os formatos maiores utilizam chapas, mas existem adaptadores construídos para permitir o uso de filmes em rolo nessas câmaras mantida a funcionalidade básica do sistema de chapas.

Atualmente, as aplicações fotográficas fazem uso apenas de filmes nas larguras de $6 \mathrm{~cm}$ e $35 \mathrm{~mm}$, tendo desaparecido, ao longo da década de 1980 o padrão 127 que tinha cerca de $4 \mathrm{~cm}$ de largura e pouco mais de 50 cm de comprimento. Esse padrão 127 era utilizado geralmente em câmaras que produziam 12 imagens quadradas com $4 \mathrm{~cm}$ de lado.

Os filmes de $6 \mathrm{~cm}$ eram apresentados em dois padrões, 120 e 620, com mesmo comprimento, cerca de $75 \mathrm{~cm}$ e diferindo apenas no formato do carretel, que no padrão 620 era de metal, mais fino e com menor diâmetro no cilindro central. Esse padrão 620 foi caindo em desuso estando hoje abandonado.

Há ainda um terceiro padrão, denominado 220, usado apenas em alguns poucos equipamentos especiais. Esse padrão usa o mesmo carretel do 120, mas não tem a fita de papel protetora enrolada junto com todo o comprimento do filme. A economia de espaço obtida com a remoção da fita de papel permite que se enrole no mesmo carretel um filme com o dobro do comprimento do padrão 120. Em cada extremidade do filme são montadas fitas curtas opacas, de papel, semelhantes às do padrão 120 , para protegê-lo da luz enquanto não está dentro da câmara.

Os filmes 120 e 620 tem cerca de $80 \mathrm{~cm}$ e 3 linhas de marcações na fita de papel protetor, para 8 imagens com $6 \times 9 \mathrm{~cm}, 12$ imagens com $6 \times 6 \mathrm{~cm}$, ou 16 imagens com $6 \times 4,5 \mathrm{~cm}$. O padrão 220, com o dobro do comprimento permite o dobro dessas quantidades em cada formato. 


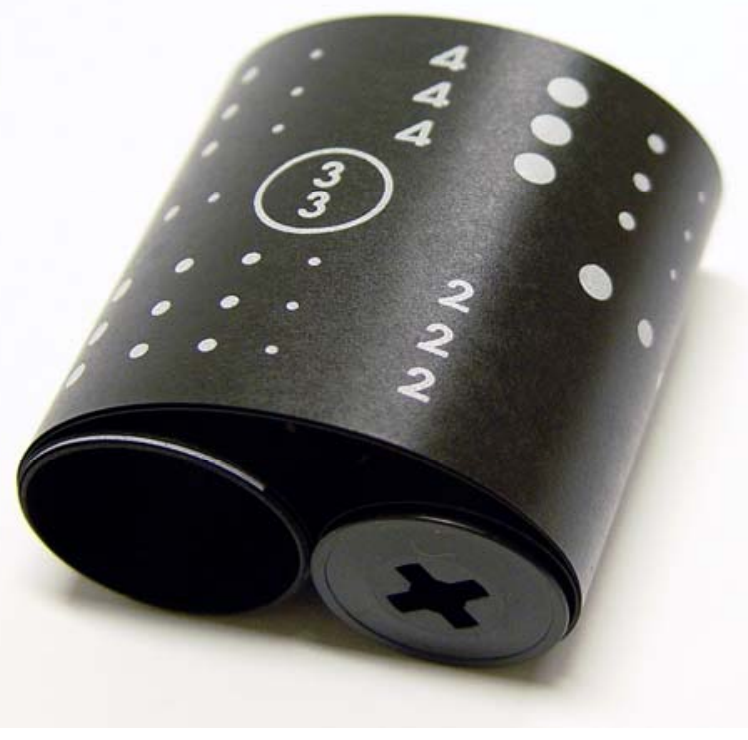

Os formatos do padrão 120/620.

As câmaras para filmes em rolo nos padrões 120/620 e 127 atenderam o mercado amador durante grande parte do século XX, só diminuindo essa participação com a expansão do uso do formato $35 \mathrm{~mm}$ pelos amadores, a partir da década de 1970.

Em 1901, o formato 120 começou a ser comercializado pela Kodak para uso com sua câmara modelo Brownie $\mathrm{N}^{\circ} 2$ e continua em uso para aplicações profissionais usando câmaras reflex como Hasselblad, Pentax, Fuji e Rollei. Todas elas utilizando modelos construtivos com uma única objetiva e espelho móvel, incluindo a Rollei que durante muitas décadas transformara-se em nome genérico para câmaras reflex de duas objetivas.

Como se destinam à aplicações profissionais, utilizam em geral um conceito de sistema modular oferecendo muitos acessórios destinados a aplicações específicas, entre os quais sempre há um visor prismático para permitir visualizar a imagem da cena na posição correta, sem inversões e 
com a câmara no nível do olho. Esse prisma, para poder cobrir o tamanho relativamente grande da imagem, acaba sendo bastante pesado e volumoso.

A maioria dessas câmaras adota o formato quadrado conhecido como $6 \mathrm{x} 6$ $\mathrm{cm}$ (na realidade $56 \mathrm{~mm}$ de lado) e assim, como as fotos são feitas sempre com câmara na mesma posição, muitas vezes opta-se por não usar o visor prismático para trabalhar com a câmara mais leve e menos volumosa, olhando pela parte superior ao fazer o enquadramento.

Os fabricantes de papéis fotográficos distribuíam os produtos em pacotes com as folhas cortadas em formatos padronizados, retangulares, quase sempre em proporções próximas a 3:4, como $18 \times 24 \mathrm{~cm}$ ou $8 \times 10$ polegadas.

Considerando o recorte necessário para fazer cópias retangulares, nessa proporção, a partir do negativo quadrado, verifica-se que o formato útil do negativo se limita a $56 \times 42 \mathrm{~mm}$ ou seja apenas $3 / 4$ da dimensão do lado, com área útil de $2352 \mathrm{~mm}^{2}$. Fazer fotos verticais ou horizontais mantendo a câmara na mesma posição significa um desperdício de $25 \%$ na área total do filme.

Contudo, nem sempre ocorre a perda de área, pois muitos fotógrafos começaram a trabalhar a composição e o enquadramento assumindo, como opção de linguagem, o formato quadrado do filme, como por exemplo, nas fotos de Diane Arbus ou de Cristiano Mascaro.

Usando a largura do filme como dimensão maior do fotograma, o formato clássico de $6 \times 9 \mathrm{~cm}$ (a rigor, $56 \times 86 \mathrm{~mm}$ ) apresenta também alguma perda, pois sua proporção de 2:3 é mais longa que a dos papéis ao fazer cópias, o formato útil é de $56 \times 74 \mathrm{~mm}$, com $4144 \mathrm{~mm}^{2}$ ou $76 \%$ mais do que no caso do negativo quadrado. Buscando otimizar a 
utilização da área desses filmes, surgem os chamados formato "ideais" de $6 \times 7 \mathrm{~cm}(56 \times 70 \mathrm{~mm})$ e $6 \times 8 \mathrm{~cm}(56 \times 80 \mathrm{~mm})$.

E há um retorno do formato $4,5 \times 6 \mathrm{~cm}(44 \times 56 \mathrm{~mm})$, desta vez como formato horizontal, usando o movimento vertical do filme, como na solução construtiva básica das câmaras reflex de $6 \times 6 \mathrm{~cm}$.

Junto com o formato retangular volta o problema do visor reflex ao girar a câmara para fotografar imagens em outra orientação que alguns modelos resolvem usando um dispositivo de montagem giratória para o chassi com o rolo de filme. Nos demais modelos, ao fazer fotos em orientação vertical (retrato) a solução era mesmo usar o visor prismático.

No geral, esses equipamentos são bastante parecidos com a referência estabelecida pelas câmaras Hasselblad, em que o filme percorre trajeto sinuoso e os carretéis ficam atrás do plano de formação da imagem. A exceção fica por conta da câmara Asahi Pentax $6 \times 7$ em que o filme corre entre os dois lados da caixa do viso reflex, fazendo com que ela se assemelhe mais com uma versão em tamanho avantajado de uma câmara reflex $35 \mathrm{~mm}$.

Os filmes 120 são usados ainda em algumas câmaras com visor Albada como nos modelos Fujica, produzidos pela Fuji e em câmaras projetadas especialmente para o registro de imagens panorâmicas fabricadas também pela Fuji no Japão e pela Linhof na Alemanha, além de magazines especiais que permitem o uso desses filmes em câmaras profissionais de geometria variável projetadas originalmente para uso com filmes em chapas.

Ao lado da versatilidade do padrão com $6 \mathrm{~cm}$ de largura que suporta formatos entre $4,5 \mathrm{~cm}$ e $17 \mathrm{~cm}$, os aperfeiçoamentos tanto das películas, como também dos sistemas óticos, verificados durante as últimas décadas ajudam a explicar a longevidade do padrão. Aplicações de alta 
qualidade que exigiam formatos maiores foram com o passar do tempo tendo condições de ser atendidas pelos assim chamados "formatos médios".

Hoje, no início do século XXI, o uso de filmes em chapas é muito restrito e o filme 120 pode ser considerado, nesta época de alta miniaturização, quase que um formato "grande".

O formato $35 \mathrm{~mm}$.

O filme com $35 \mathrm{~mm}$ de largura foi desenvolvido para aplicações de registro de imagens cinematográficas. Inspirado no movimento intermitente de transporte utilizado em máquinas de costura, Edison percebeu que o uso de um sistema de rodas dentadas seria eficiente para transportar o filme com perfurações.

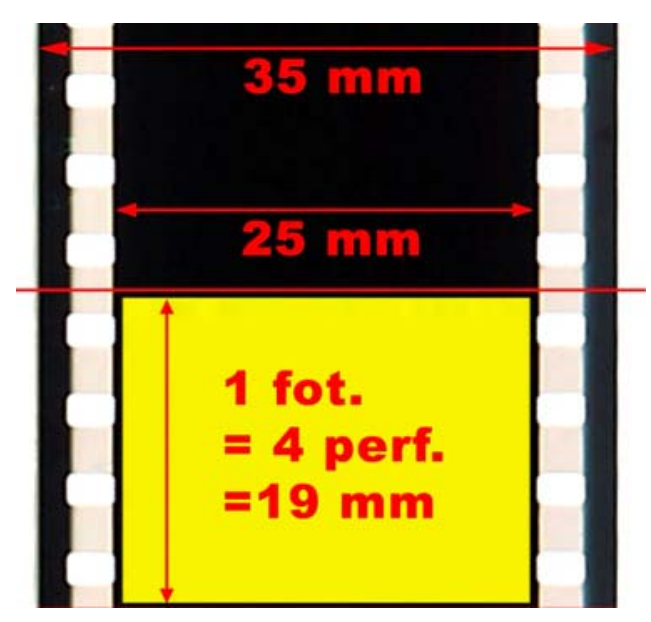

Cada fotograma usava a altura de quatro perfurações e, adotado o padrão criado por Edison, a demanda da indústria cinematográfica determinou que esse formato logo fosse produzido em larga escala. 
$\mathrm{Na}$ década de 1920, na Alemanha, surge uma câmara fotográfica utilizando esse formato de filme. Seu inventor, o engenheiro Oskar Barnack, trabalhava como gerente de desenvolvimento na fábrica Leitz e já em 1905 pensava na idéia de registrar imagens pequenas e fazer depois cópias maiores por projeção. O protótipo do equipamento ficou pronto em 1915, feito a partir de um instrumento para fazer testes de exposição com filmes cinematográficos. A primeira guerra mundial fez com que a produção industrial dessa câmera fosse ocorrer apenas em 1924.

Barnack adotou o movimento horizontal do rolo de filme e um formato ocupando oito perfurações, com dimensões de 24 x $36 \mathrm{~mm}$, correspondendo a dois fotogramas cinematográficos e com proporção de $2: 3$, um pouco mais longa do que a de $3: 4$ do cinema. Bastante pequeno para os padrões vigentes na época de seu surgimento, ficou conhecido durante muito tempo como "formato miniatura".

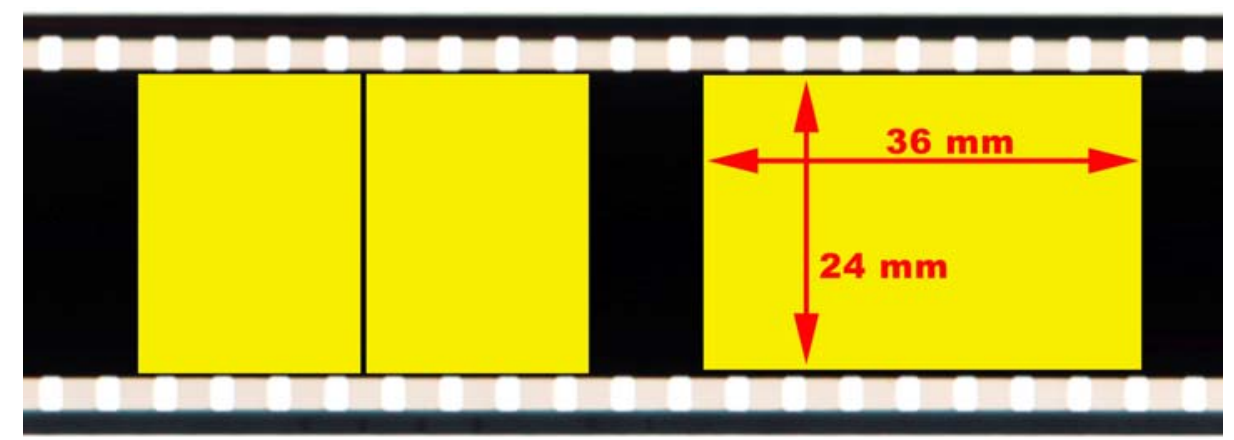

Considerando o uso estático da imagem, o formato é bastante perdulário pois quase metade da altura do fotograma é "desperdiçada" pela área de transporte com perfurações. Essa aparente fraqueza do formato acabou se mostrando importante em seu sucesso. $\mathrm{O}$ formato $35 \mathrm{~mm}$ fotográfico herdou do cinema a solução para o transporte e posicionamento exato do filme que seria ainda adaptada em alguns formatos décadas depois, e foi fator determinante no desenvolvimento de equipamentos automatizados, 


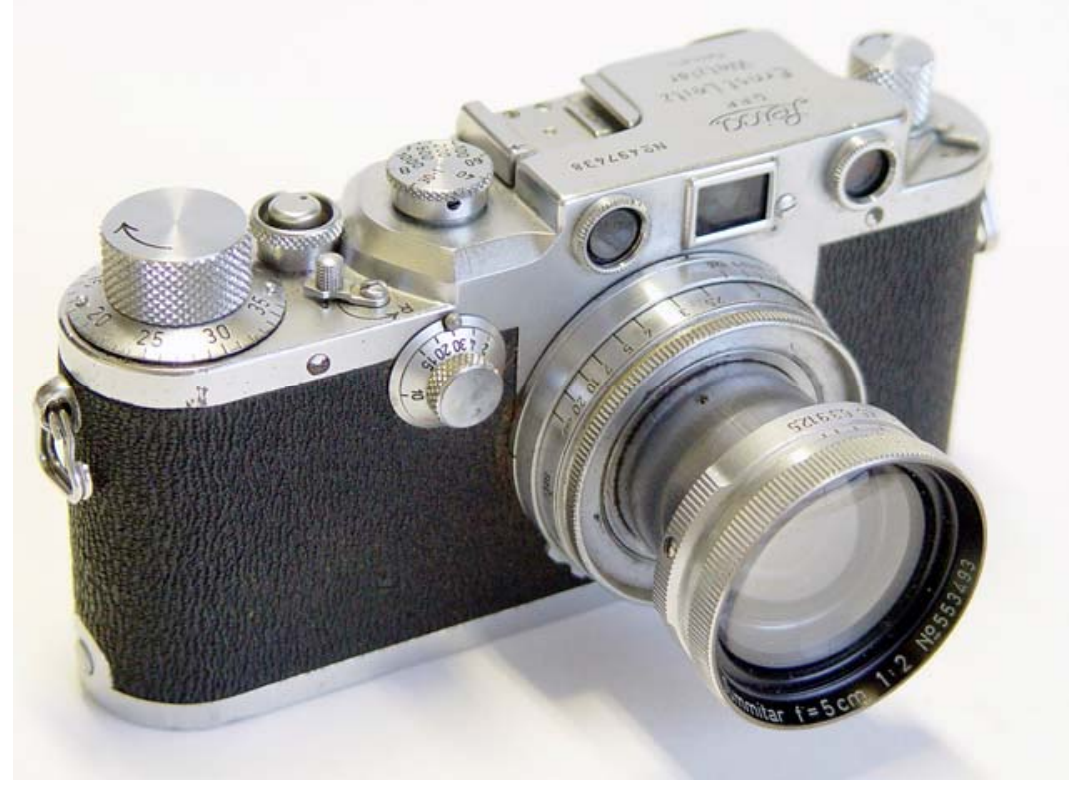

A Leica IIIc, máquina da década de 1940, estava longe de ser um equipamento fácil de usar, a começar pela operação de carregamento do filme em que se devia remover o carretel recolhedor, prender a ponta do filme e recolocar o carretel, introduzindo o filme em uma fenda e ajustando sua posição no canal de corrimento onde ficava a janela de exposição.

A escala de diafragma nas objetivas dessa época ainda era diferente da escala padronizada que se estabeleceu ao redor dos anos 1960. O ajuste do obturador se fazia em duas escalas diferentes, uma para tempos curtos de exposição, na faixa de 1/1000 de segundo até 1/30 de segundo e outra para os tempos entre $1 / 30$ de segundo e 1 segundo. 


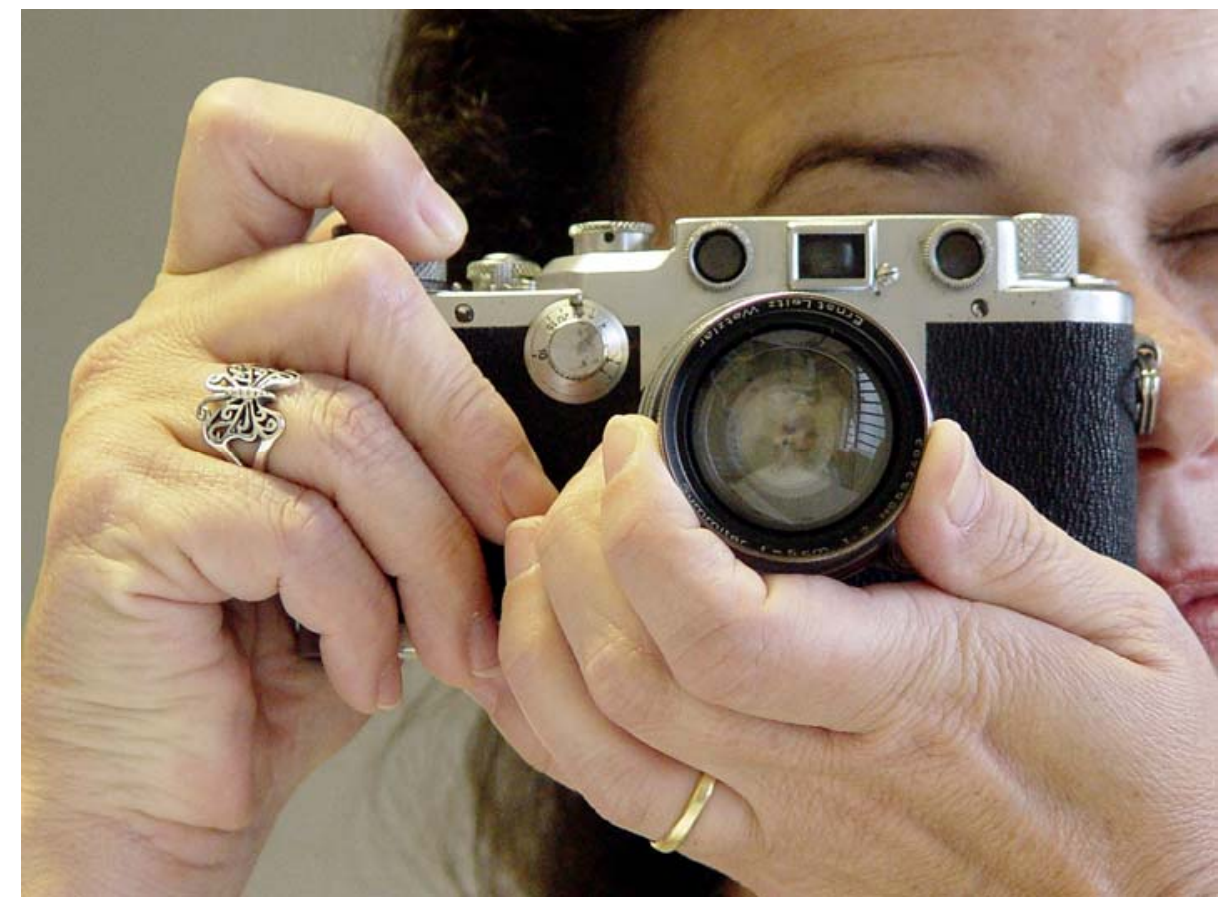

$\mathrm{O}$ visor era bastante pequeno tornando difícil o enquadramento, principalmente para quem usasse óculos. A câmara tinha um telêmetro embutido para auxiliar no ajuste da distância focalizada que interagia diretamente com o anel de focalização da objetiva, mas a janela desse dispositivo auxiliar de foco era separada da janela de enquadramento.

Um botão redondo, recartilhado servia para avançar o filme e armar o obturador.

O contador de fotogramas devia ser ajustado manualmente ao carregar um novo filme.

O filme exposto era rebobinado para seu carretel original liberando o mecanismo interno de transporte, por meio de uma pequena alavanca, e girando um botão recartilhado, menor do que o de transporte, situado na parte superior da câmara, do lado oposto ao de transporte. O pequeno diâmetro desse botão tornava a operação bastante difícil, principalmente na fase final de recolhimento de um filme longo. 


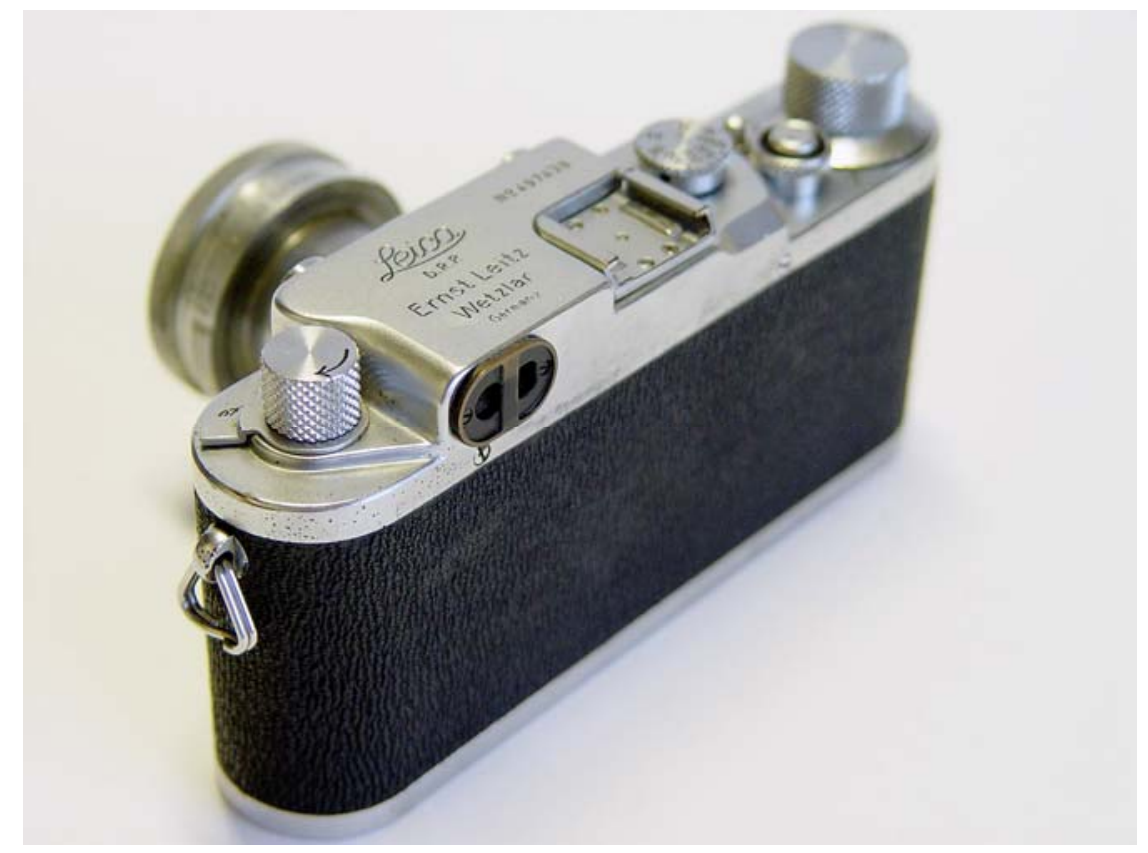

As Leicas, com exceção de um primeiro modelo, sempre permitiram o intercâmbio de objetivas, mas era preciso usar um visor externo auxiliar para fazer o enquadramento.

A fábrica chegou a produzir um visor auxiliar múltiplo que servia para objetivas de várias distâncias focais, bastando girar um anel com diversas lentes.

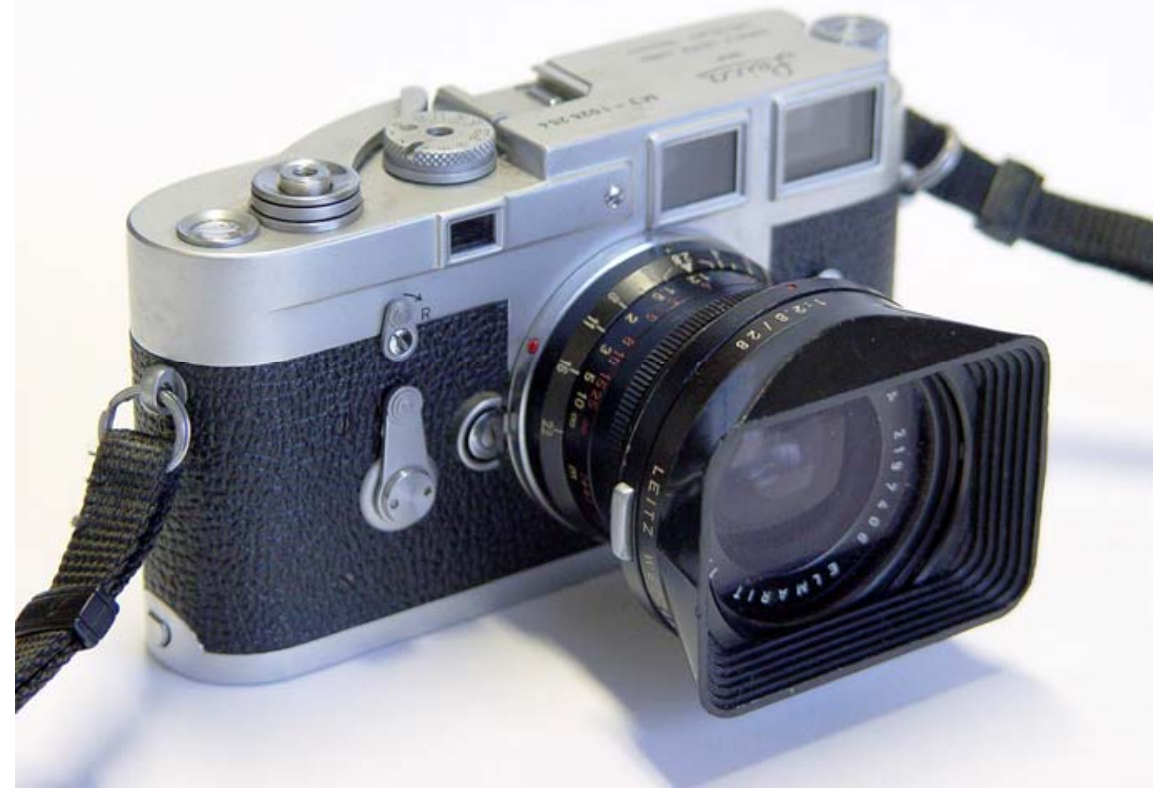


Em 1954 a fábrica Leitz introduz sua nova linha "M" completamente redesenhada, desde a montagem das objetivas no corpo que passou a ser feita por baioneta, abandonando a rosca padrão M39X1. O transporte do filme passou a ser feito por uma alavanca. O carregamento do filme continuou sendo feito na parte inferior da câmara, mas, na face traseira, um painel basculante tornou mais fácil o ajuste da posição do filme. $\mathrm{O}$ contador de fotogramas passou a zerar automaticamente ao carregar um novo filme. $\mathrm{O}$ visor passou a ser do tipo Albada, como o da imagem abaixo com marcas de enquadramento para as objetivas de distâncias focais próximas às da objetiva normal, que se alteravam automaticamente com a troca das objetivas. Com isso, restou a exigência de visores externos adicionais, apenas para as objetivas de distâncias focais bastante mais curtas ou mais longas do que a lente normal de 50 $\mathrm{mm}$. O telêmetro foi aperfeiçoado e a janela de focalização foi incorporada ao visor principal.

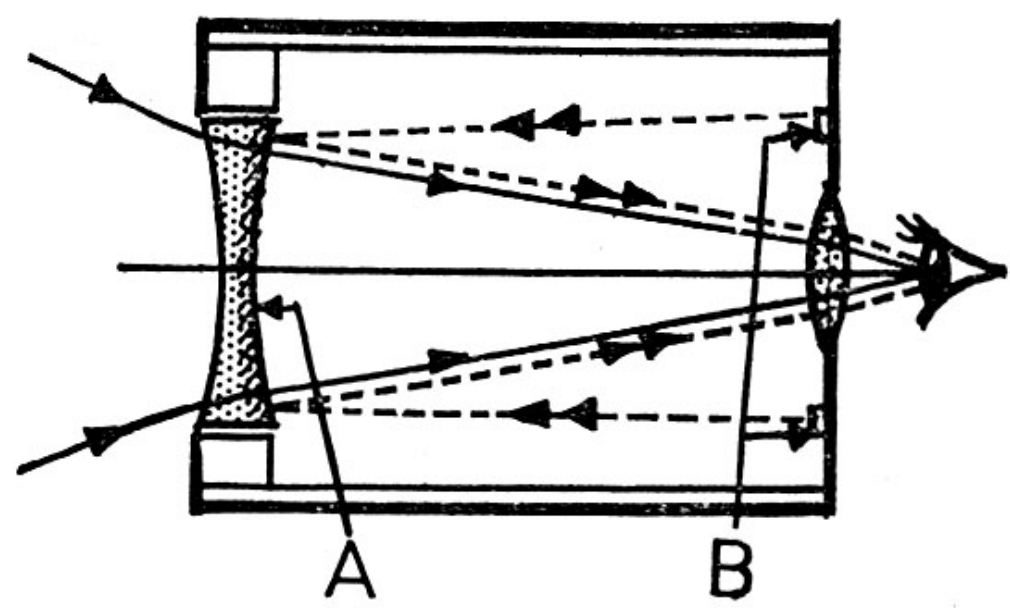

Como se tratava de uma evolução da Leica III, recebeu a denominação de M-3. Depois surgiram modelos mais simples, como a M-2 em que o contador de fotogramas não zerava automaticamente e a M-1 que não tinha visor, sendo usada para fotografias obtidas em mesas de reprodução especiais ou acoplada a microscópios. A operação de rebobinagem continuou a ser feita usando um botão recartilhado apenas com diâmetro um pouco maior do que na linha anterior e que só foi 
substituído por uma alavanca retrátil no modelo M-4, produzido uns 15 anos depois. A incorporação de um fotômetro só viria a ocorrer no modelo M-5 em 1971 e o controle automático de exposição ficou para a M-6 de 1984.

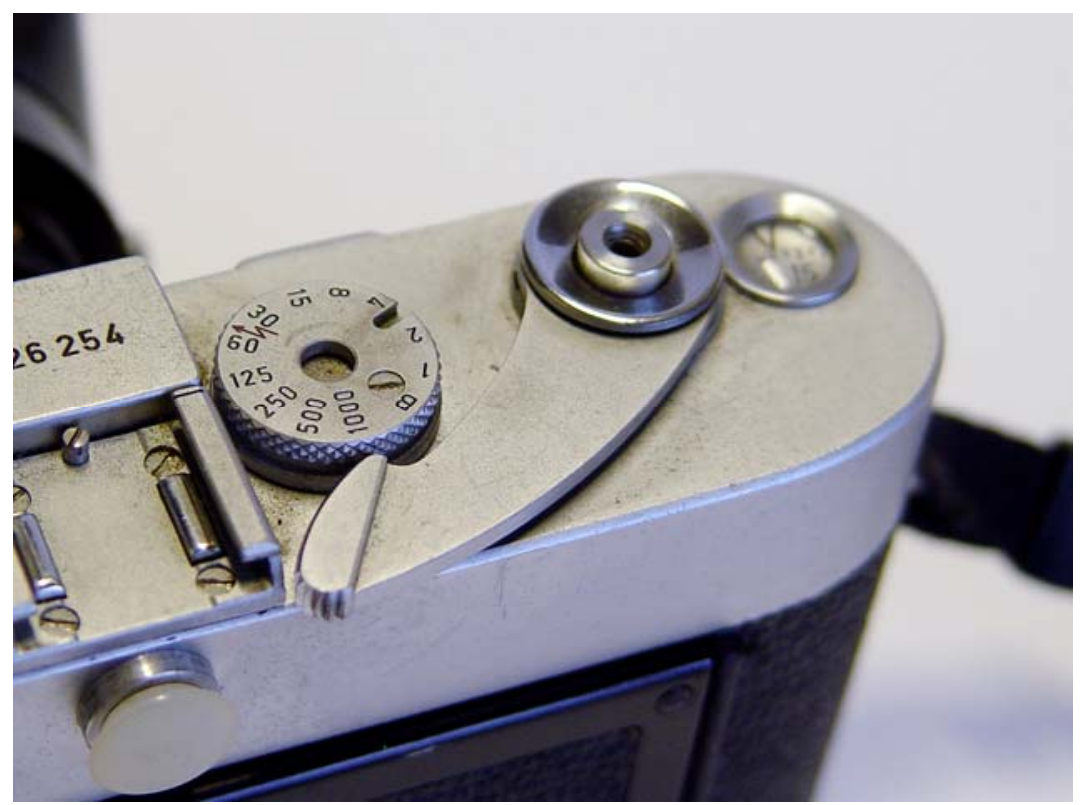

A alavanca de transporte na Leica $M$, junto com a integração do telêmetro ao visor, fez com que a operação se tornasse mais confortável do que com os modelos anteriores, mas, muito mais importante, com isso era possível disparar o obturador e rearmar a câmara para a foto seguinte, sem tirar o olho do visor.

O visor deixa de ser um simples dispositivo de enquadramento e passa a ser uma interface do fotógrafo com a cena e também com o controle do processo em si.

As câmaras Leitz sempre foram referências em termos de qualidade ótica e mecânica. Foram adotadas com entusiasmo por muitos profissionais, 
mas devido ao seu preço elevado, nunca foram equipamentos de largo consumo.

A difusão do formato $35 \mathrm{~mm}$ vai ocorrer a partir do surgimento de equipamentos produzidos por outros fabricantes, principalmente no Japão, a partir do fim da $2^{\text {a }}$. Guerra Mundial e do aperfeiçoamento de uma classe de câmaras, com visor reflex, a partir do lançamento da Asahi Pentax em 1957 com um conjunto de características que viriam a formar um padrão nessa classe equipamentos. Essas câmaras japonesas, colocadas no mercado com preços bem mais acessíveis do que os produtos alemães foram responsáveis pela popularização do formato na segunda metade do século XX.

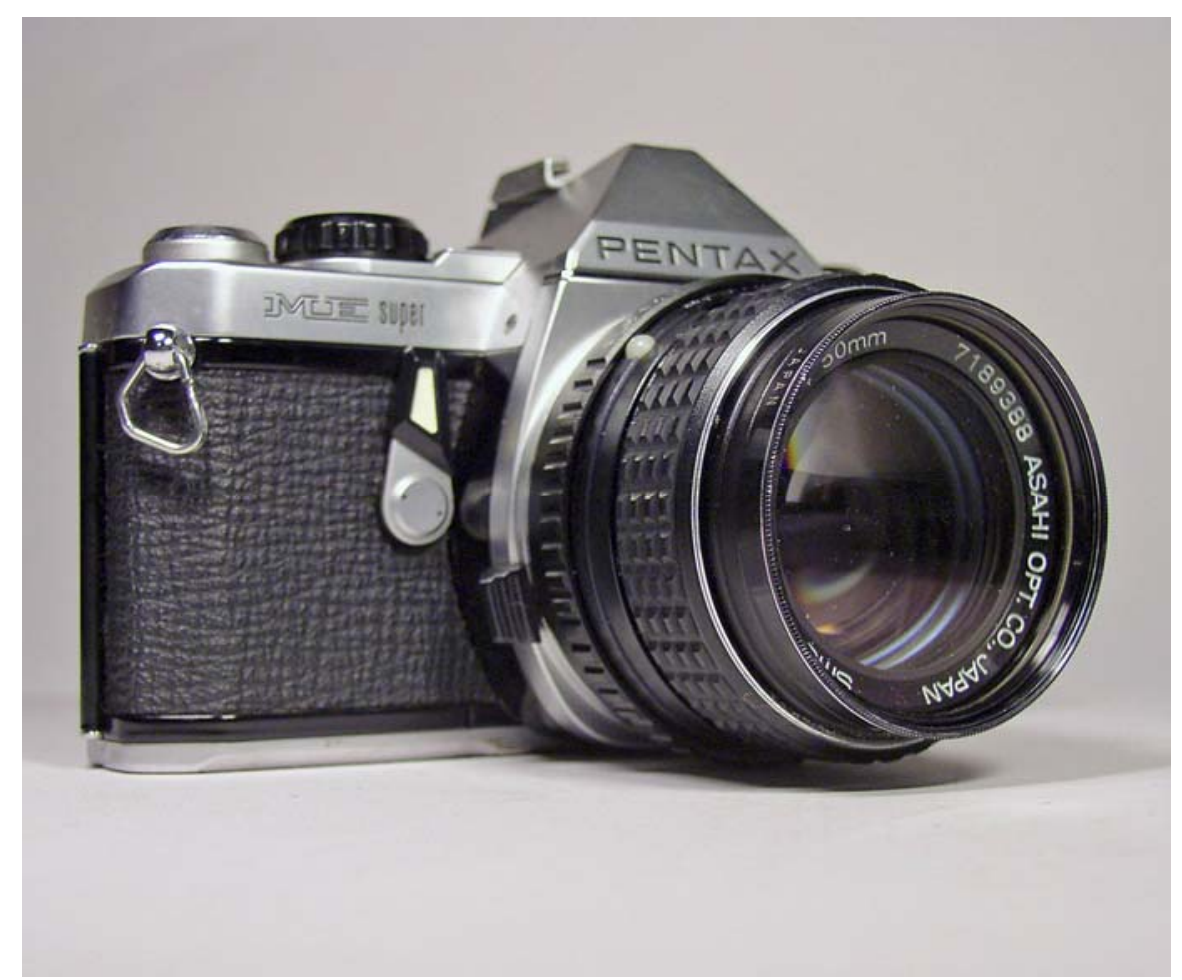

Foto de uma câmara Asahi Pentax, em modelo eletrônico, da década de 1990. 


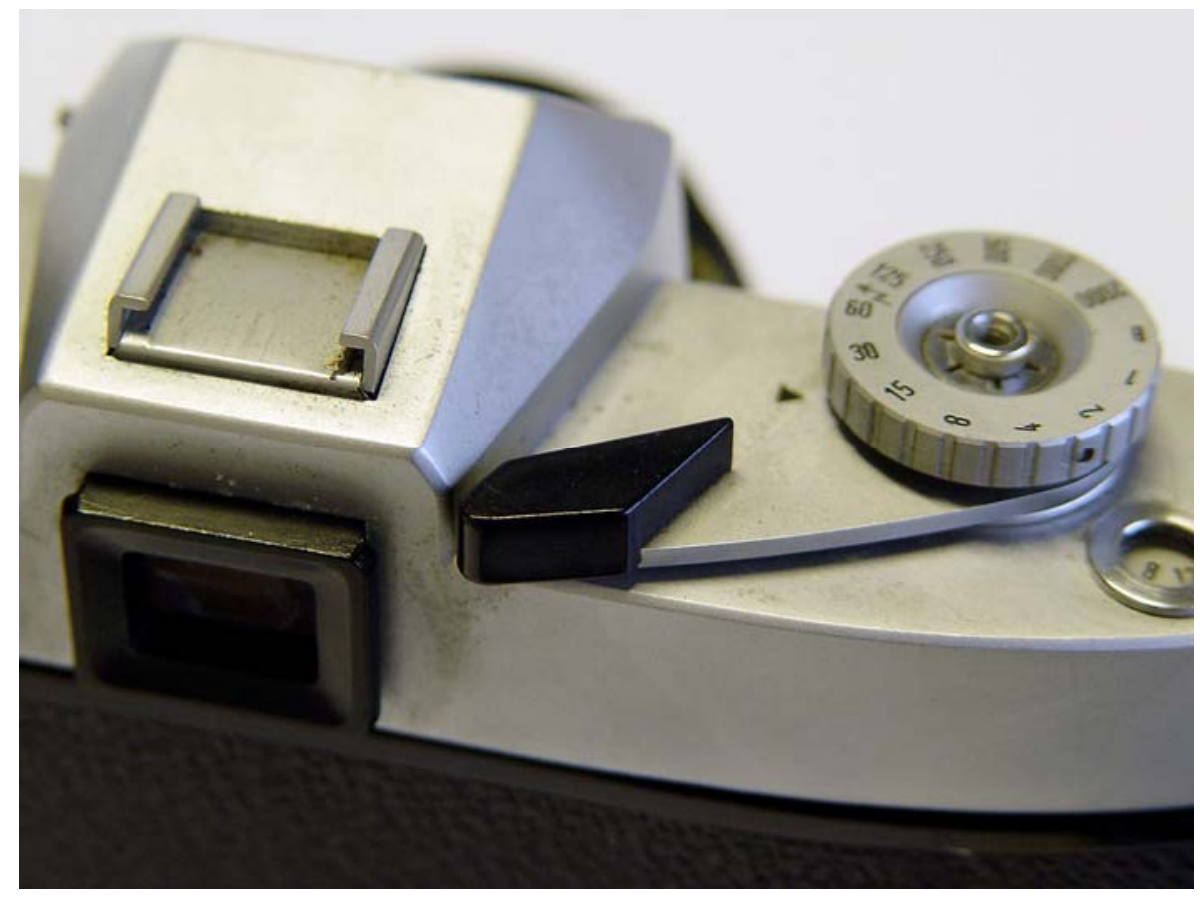

Na década de 1960, surge a primeira câmara reflex produzida pela Leitz, com a marca Leicaflex. A parte traseira do corpo dessa câmara é levemente curva, para facilitar a acomodação do rosto na ocular do visor. A alavanca de transporte, a comando de ajuste do tempo de exposição e o botão de disparo são concêntricos, permitindo fácil operação com os dedos da mão direita. O obturador permite exposições de até 1/2000 de segundo. Na sua primeira versão, o fotômetro tinha uma janela de leitura na parte dianteira do prisma do visor. Pouco depois uma nova versão denominada SL faz a medição da luz através do próprio sistema de visor, com a célula foto sensível, um foto resistor de sulfeto de cádmio, colocada no fundo da câmara, dentro da caixa reflex do visor.

Um pouco mais tarde, na década de 1970, surgem os primeiros modelos em que o controle do obturador deixa de ser feito por mecanismos de relojoaria.

As molas que acionam as cortinas são ainda armadas junto com o transporte do filme, pela alavanca de transporte. Mas a liberação do movimento é controlada por um circuito eletrônico de precisão que 
aciona um solenóide. Essa série foi denominada Leica $\mathrm{R}$ e o primeiro modelo lançado foi o R3. Três anos depois surge versão que permitia a montagem de um motor para automatizar as operações de transporte e carregamento do obturador, denominada R3 Mot.

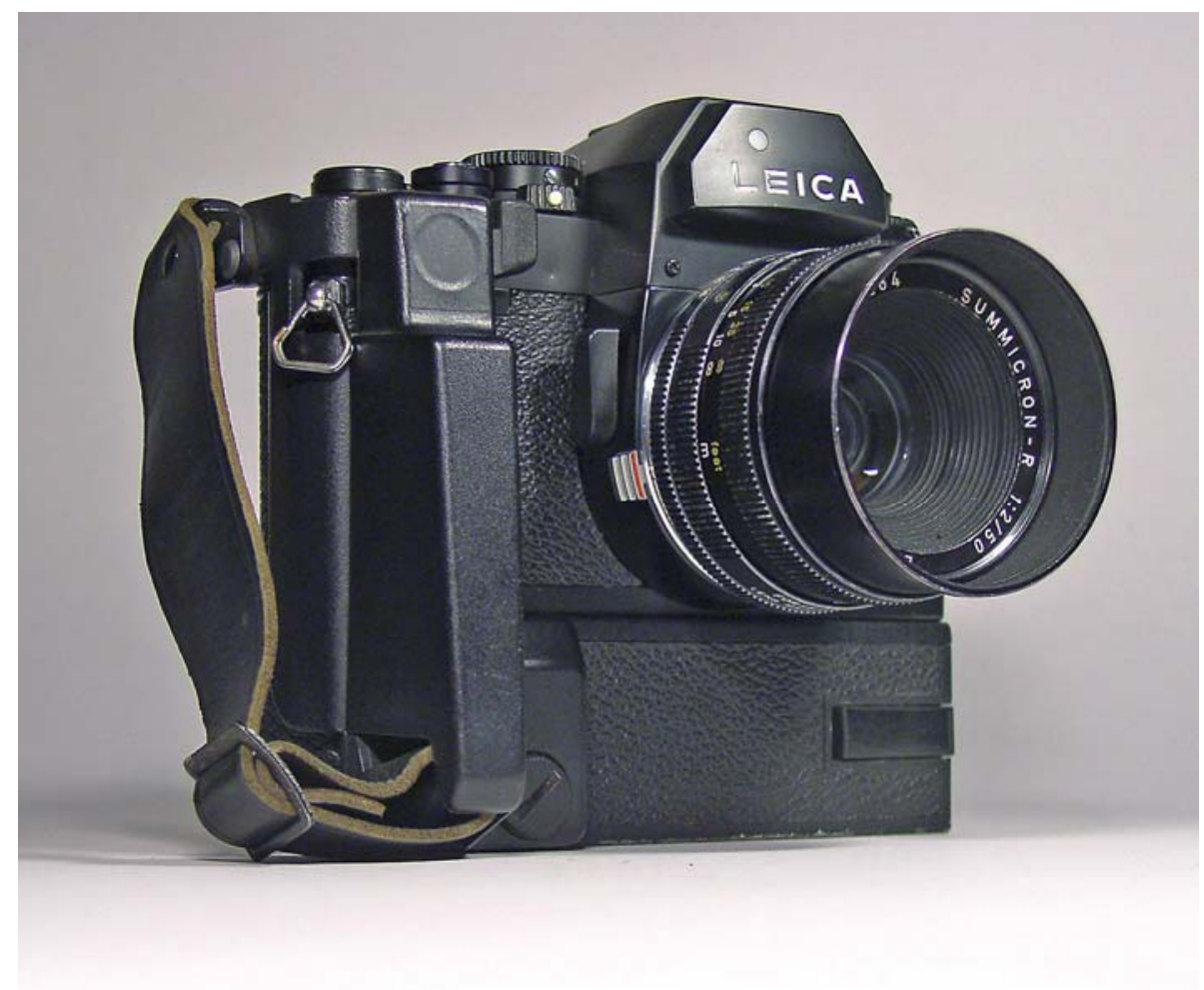

O visor mostra, além da imagem, as informações relevantes referentes ao controle do equipamento permitindo que o operador trabalhe sem precisar afastar o câmara do olho. 


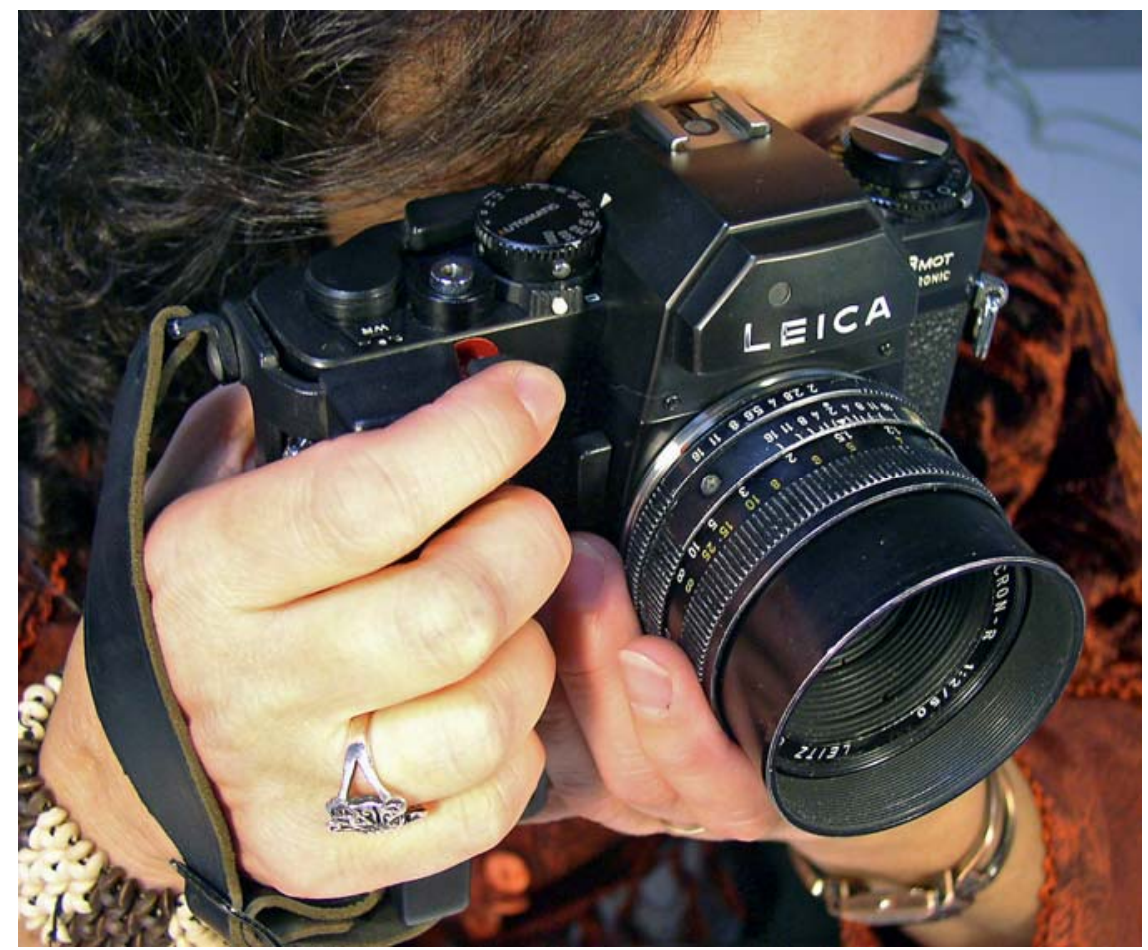

Essa linha foi sendo aperfeiçoada com o lançamento de novos modelos até o modelo R9 que se encontra em linha atualmente. Esse modelo oferece, basicamente a mesma funcionalidade da R3, isto é controle automático exposição automática e pode ser motorizada. A focalização permanece manual. A parte traseira do corpo pode ser substituída por um conjunto eletrônico para captação digital. O corpo dessa câmara, equipado com o motor e uma objetiva zoom de uso geral, custa hoje algo ao redor 5.000 dólares; o módulo digital, outros 6.000, o que a coloca na categoria dos objetos de luxo, principalmente quando se leva em conta que uma câmara digital de outra marca, mas usando também objetiva Leitz, e equipada com sensor eletrônico que produz imagens com a mesma resolução de 10 megapixel, é vendida por menos de 600 dólares.

Essa variação extrema de preço é indicativa de um fenômeno que se verificou desde o surgimento dos processadores digitais. $O$ desenvolvimento de circuitos dedicados exige investimentos pesados o que faz com que produtos com tecnologia avançada tenham preço elevado quando são lançados. Tal aspecto se agrava devido ao ritmo 
acelerado no ciclo de desenvolvimento de novos produtos que obriga a procurar rápida amortização dos investimentos. Por outro lado, amortizado o custo e entrando em um novo ciclo de desenvolvimento, a tecnologia anterior não é descartada, mas fica disponível para difusão em produtos com custos mais baixos. Visando reduzir mais ainda os custos, esses produtos são projetados prevendo já um ciclo de vida mais curto o que faz sentido quando se considera a velocidade com que as mudanças de patamar tecnológico vêm ocorrendo. Isso conduz a equipamentos que, de forma semelhante aos computadores, oferecem recursos sofisticados, mas são semi-descartáveis, porque acabam sendo substituídos mesmo antes de se tornarem obsoletos.

A partir de meados da década de 1980, com a crescente automatização dos processos de manufatura, começam a se popularizar câmaras em que além do ajuste da exposição, a focalização é também automática e ainda o transporte do filme é motorizado. O fotógrafo apenas olhava pelo visor e apertava o botão, de forma semelhante ao que se fazia nas primeiras câmaras Kodak. Só que agora o equipamento estava pronto para outra foto, uma mera fração de segundo após o fechamento do oturador, antes mesmo que o fotógrafo tivesse tempo de afastar o olho do visor.

Como sempre, os primeiros modelos eram bastante caros para os recursos que ofereciam, mas logo ocorria a difusão e em pouco tempo, com o surgimento de novos modelos mais sofisticado, os preços caiam. No geral, com o passar do tempo, ia aumentando a qualidade do equipamento que se podia comprar por determinado valor, seguindo uma tendência que se instala junto com a expansão dos equipamentos de informática. Em pouco tempo, muitas dessas câmaras, voltadas para o mercado amador, começam também a oferecer objetivas de tipo zoom, com distância focal variável, algumas com qualidade mais do que suficiente para permitir a realização de trabalhos bastante sofisticados 
como, por exemplo, as fotomontagens de David Hockney, de que voltaremos ainda a tratar.
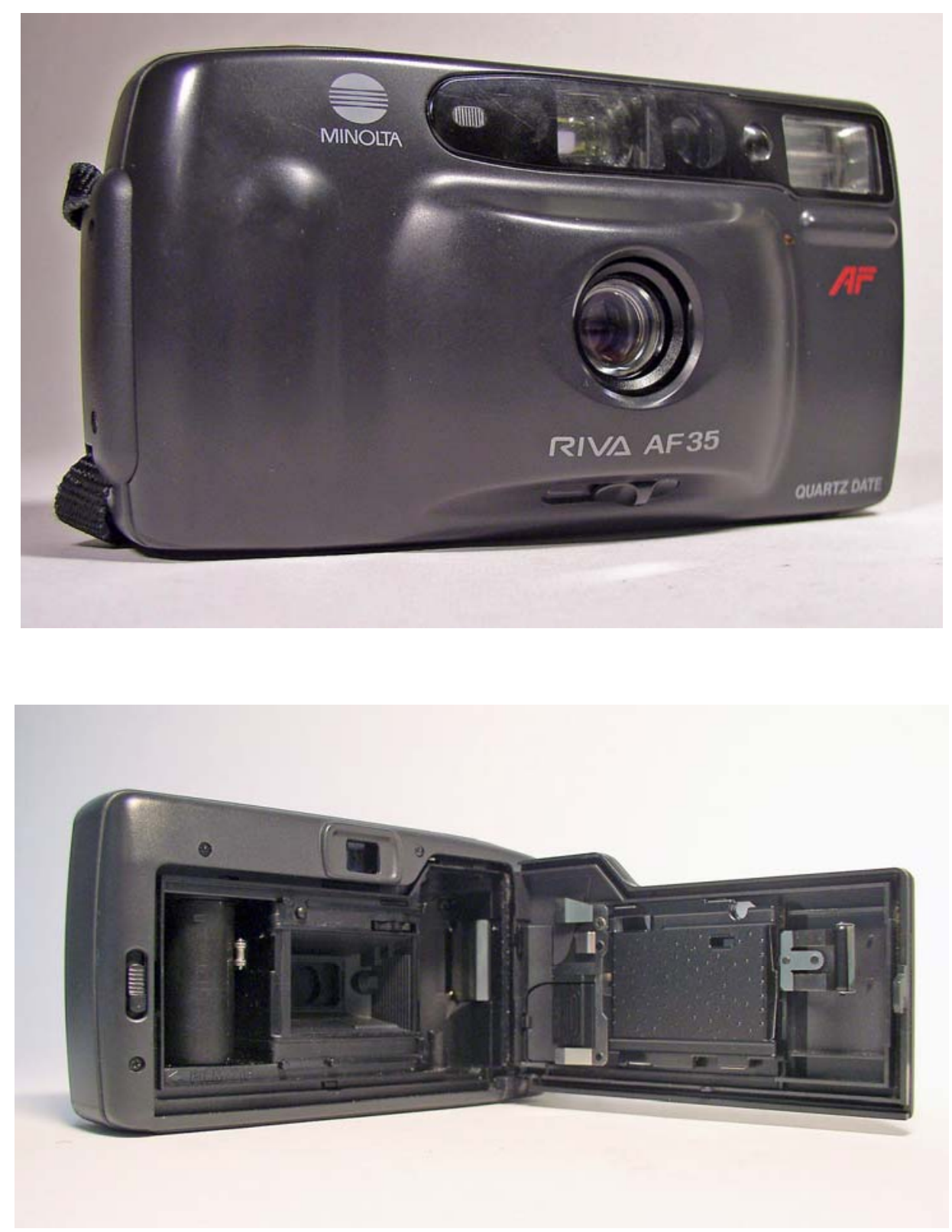

No momento atual o formato $35 \mathrm{~mm}$ perdeu a posição predominante que ocupou durante meio século. Encontra-se ainda em uso, mas tudo leva a crer que isso vá diminuindo gradualmente até chegar a um nível praticamente residual. 
As câmaras de uso amador fortemente automatizadas têm, como dissemos, vida útil relativamente curta e estão sendo substituídas gradativamente por modelos digitais cada vez menores.

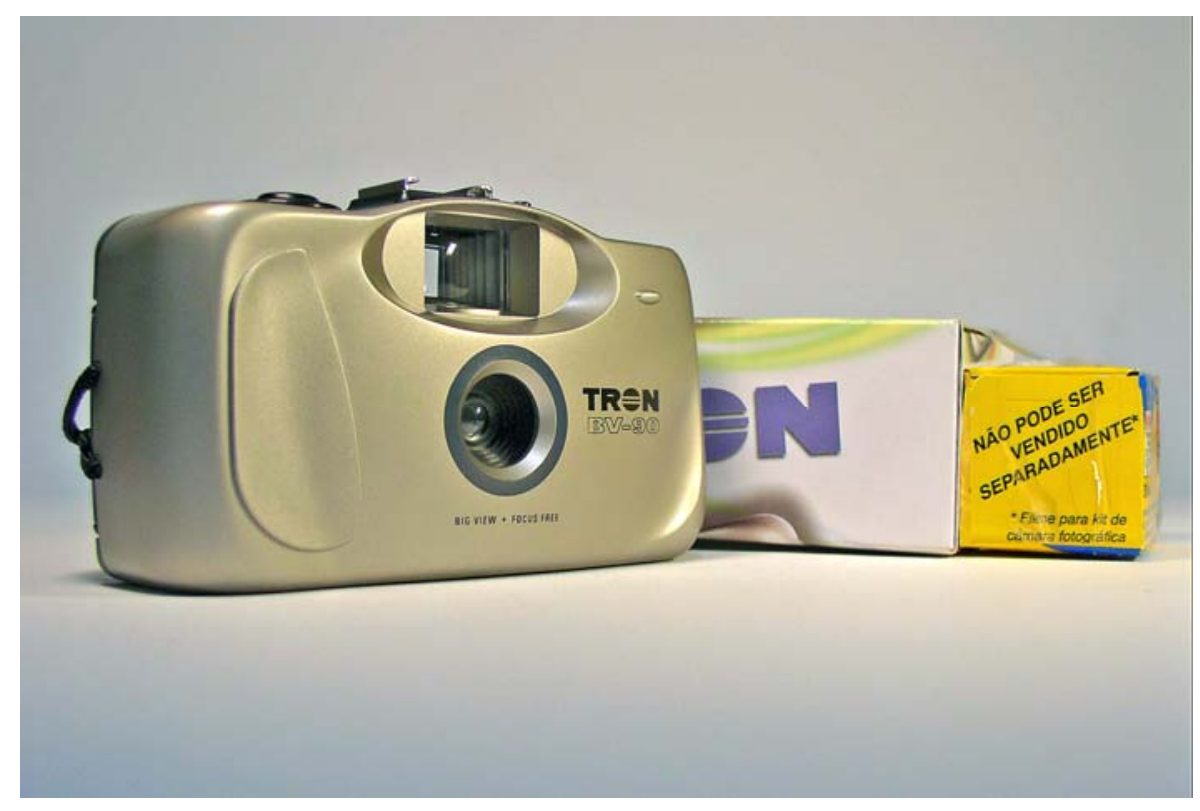

$\mathrm{Na}$ imagem acima um dos últimos modelos de câmara básica $35 \mathrm{~mm}$, junto com um rolo de filme, fornecido pela Kodak ao distribuidor da câmara, com preço subsidiado, para venda casada. O conjunto se vendia em 2004 pelo mesmo preço que se pagaria para comprar apenas o filme.

No caso das câmaras destinadas ao uso profissional, com sistemas modulares, a transição muitas vezes se dá a partir do uso de um modelo digital que ofereça compatibilidade com o anterior, de forma a permitir o uso de objetivas e de acessórios já existentes. $\mathrm{Na}$ contramão da tendência geral de miniaturização esses equipamentos têm apresentado soluções bastante pesadas e volumosas em parte para atender uma demanda de fotógrafos que preferem continuar usando o visor ótico reflex, com espelho basculante, mesmo em uma câmara eletrônica em que não há um filme que precisa ser protegido da luz. Com efeito, nas câmaras digitais, a ação do disparador é apenas um comando para que os 
valores correntes no dispositivo de captação sejam processados e armazenados na memória.

Formatos sub-miniatura.

Desde os primórdios da fotografia sempre houve equipamentos que produziam imagens minúsculas e que eram camuflados dentro de relógios ou outros objetos. Mas eram produtos feitos de modo praticamente artesanal, produzidos em pequena escala. Eram ainda produtos dispendiosos que nunca tiveram grande popularidade.

A indústria de filmes sempre teve interesse em reduzir o formato dos fotogramas. A fabricação se dá em unidades de área enquanto que a venda para o fotógrafo ocorre em unidades de fotogramas. Assim, quanto mais fotogramas, se puder fazer por metro quadrado de filme, mais interessante se torna, em princípio, o negócio. A tendência geral e conhecida é que, ao usar formatos menores sejam feitas mais fotos. $\mathrm{O}$ que significa mais cópias, usando maior quantidade de papel fotográfico, produzido também pela mesma indústria.

Utilizando o mesmo filme de $35 \mathrm{~mm}$ de largura, um dos formatos menores reduzia pela metade a área de cada fotograma que ficava assim com tamanho semelhante ao do fotograma cinematográfico. Esse formato ficou conhecido como meio-quadro. A câmara que melhor representou esse formato foi a Olympus Pen. Foi fabricada durante cerca de duas décadas, entre meados das décadas de 1960 e de 1980, oferecendo certa variedade de modelos. Em sua fase final chegou a ter uma versão com visor reflex e objetivas intercambiáveis, mas no geral eram máquinas de uso bastante simples com exposição ajustada automaticamente e apenas alguns ícones na escala de focalização: uma montanha para o infinito, um 
grupo de pessoas para 3 metros e uma pessoa em meio corpo, para 1 metro.

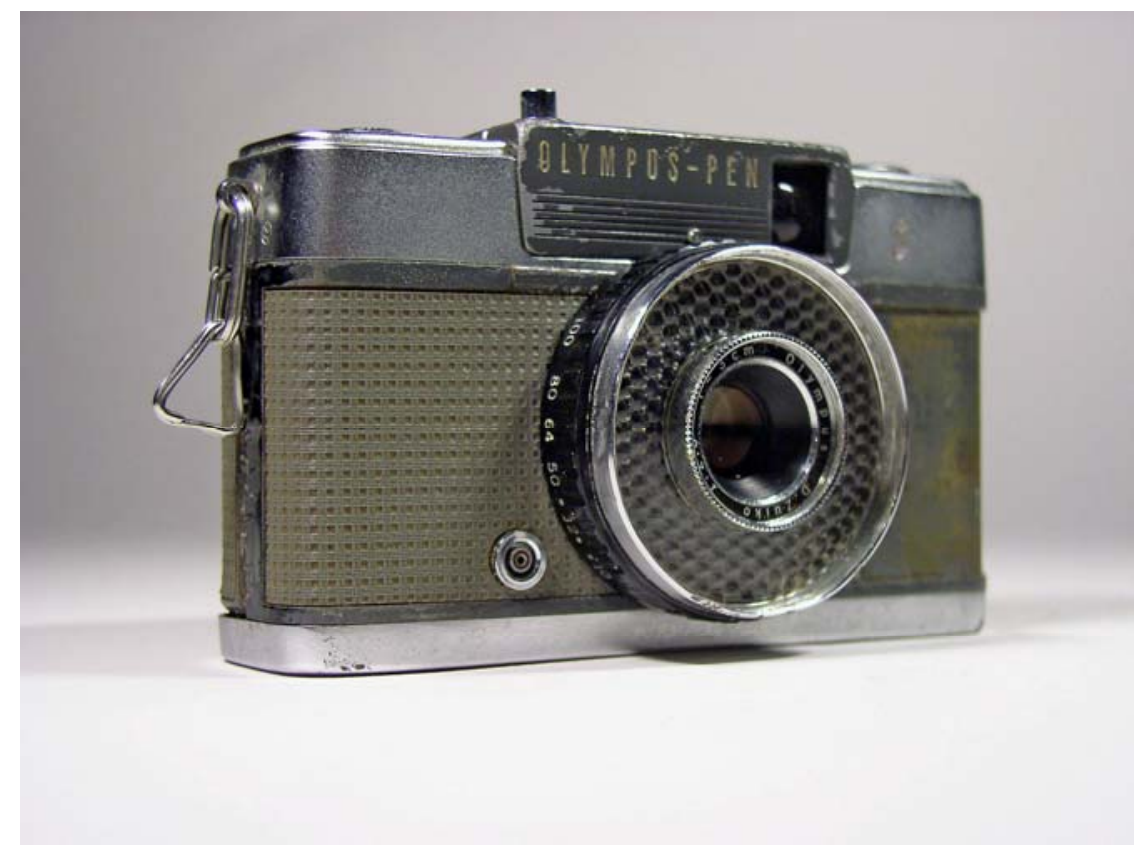

Com o formato meio quadro, produziam o dobro de fotogramas, chegando a 72 imagens por filme. Ao lado da economia no custo do filme surgiam, contudo alguns problemas: o filme muito longo demorava muito para acabar e ser enviado ao laboratório. Muitas vezes quando ele era revelado as imagens já haviam começado a se deteriorar. E por vezes os clientes se assustavam com o custo da grande quantidade de cópias. Os laboratórios não gostavam também de trabalhar com negativos pequenos que exigem maior escala de ampliação na copiagem, evidenciando eventuais marcas e sujeiras.

Mesmo assim, o uso dessas câmaras se mostrava interessante em determinadas situações. Na década de 1970, os materiais coloridos, tanto os filmes quanto as cópias, tinham ainda custo bastante elevado. O custo dos filmes reversíveis, bem como sua revelação, sempre foi maior do que o dos filmes negativos. O material reversível oferecia, contudo a vantagem de dispensar a produção de cópias e, quando usado nas câmaras de meio quadro, permitia obter uma grande quantidade de slides 
coloridos com custo bem mais acessível do que igual quantidade de cópias. Para compensar o tamanho menor das imagens, bastava colocar o projetor um pouco mais afastado da tela.

A indústria fotográfica sabe que, como em qualquer ramo de atividade, pode até ser fácil conquistar um cliente, mas mantê-lo exige certo cuidado. Os fabricantes de câmaras podem até se preocupar menos com isso pois trabalham com um produto durável, mas para as empresas que produzem filmes e papéis, o ideal é que as pessoas estejam continuamente fazendo e revelando fotos para que possam manter um fluxo estável de produção e consumo de materiais. Pesquisas junto aos fotógrafos procuram descobrir quais as dificuldades que eles encontram ao usar os produtos e serviços oferecidos e que podem provocar situações de fracasso que desestimulem as pessoas a tirar fotos. Os resultados servem para indicar diretrizes no desenvolvimento de novos produtos. Alguns dos problemas mais comuns apontados eram a dificuldade no carregamento dos filmes nas câmaras, as fotos tremidas ou fora de foco e imagens perdidas por terem sido feitas em situações com iluminação insuficiente. Vamos tratar aqui apenas da questão do carregamento do filme e voltaremos às outras mais adiante. A indústria eletrônica já conhecia problema semelhante com o carregamento dos carretéis de fitas magnéticas nos gravadores o que levou ao desenvolvimento dos cartuchos e cassetes.

No caso dos filmes houve algumas tentativas de procurar soluções semelhantes, que levaram ao desenvolvimento pela Kodak dos padrões Instamatic, padrão 126 e posteriormente Pocket Instamatic, padrão 110. 

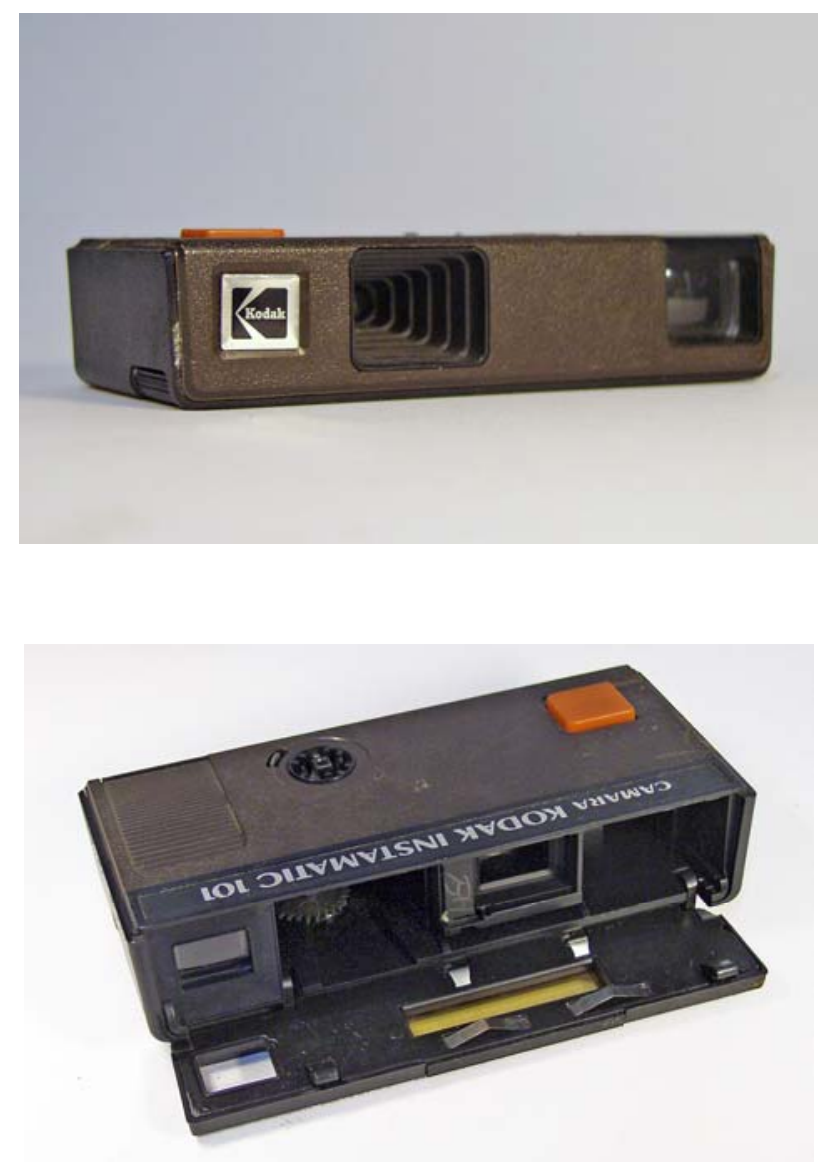

Os cartuchos eram de plástico contendo a tira de filme e um protetor traseiro de papel opaco, como nos filmes em rolos. O transporte se fazia enrolando o filme em um carretel que era acionado pela mão direita do fotógrafo. No filme havia apenas uma perfuração marcando a posição de cada fotograma. Essa perfuração, ao passar por uma alavanca de controle, determinava o bloqueio do mecanismo de transporte quando o fotograma estivesse na posição correta.

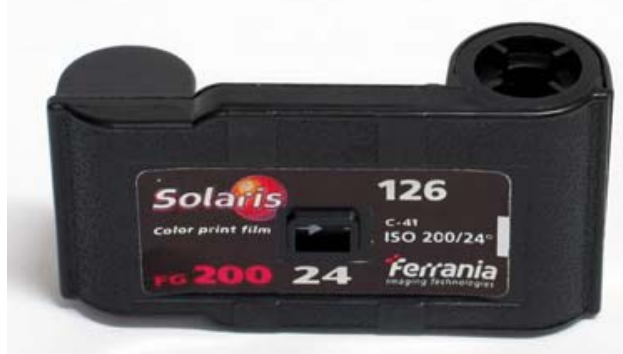


Os cartuchos 126 produziam negativos quadrados com cerca de $26 \mathrm{~mm}$ de lado sobre um filme com $35 \mathrm{~mm}$ de largura e o Pocket fotogramas de $13 \times 17 \mathrm{~mm}$ sobre filme de $16 \mathrm{~mm}$ de largura. Nos dois padrões havia cartuchos de 12 e de 20 exposições.

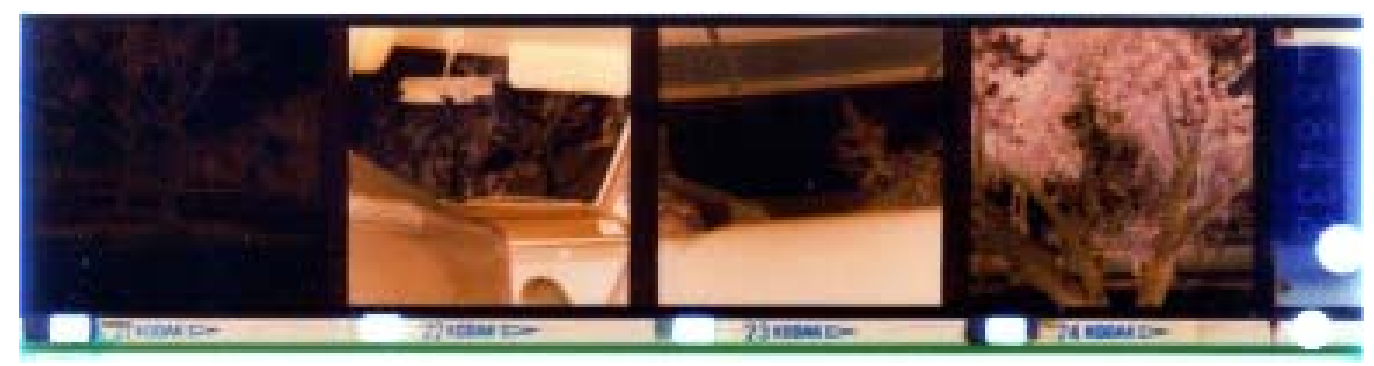

Tira de negativos em formato 126

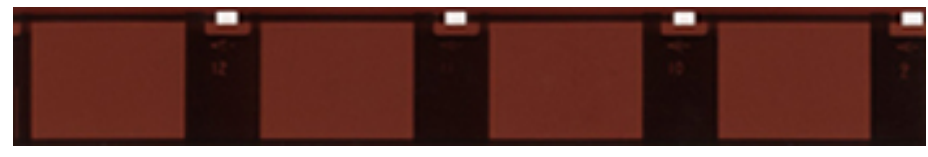

Tira de negativos em formato 110

Se os cartuchos 126 e 110 guardavam semelhança com a solução dos cassetes de áudio, a Kodak viria ainda a desenvolver um padrão que lembra os dispositivos de impressão das máquinas de escrever conhecidos como "margaridas", e mesmo os disquetes usados em computadores. O padrão "Disk" usava uma lâmina de filme com os fotogramas situados em disposição radial, como se vê na imagem abaixo.

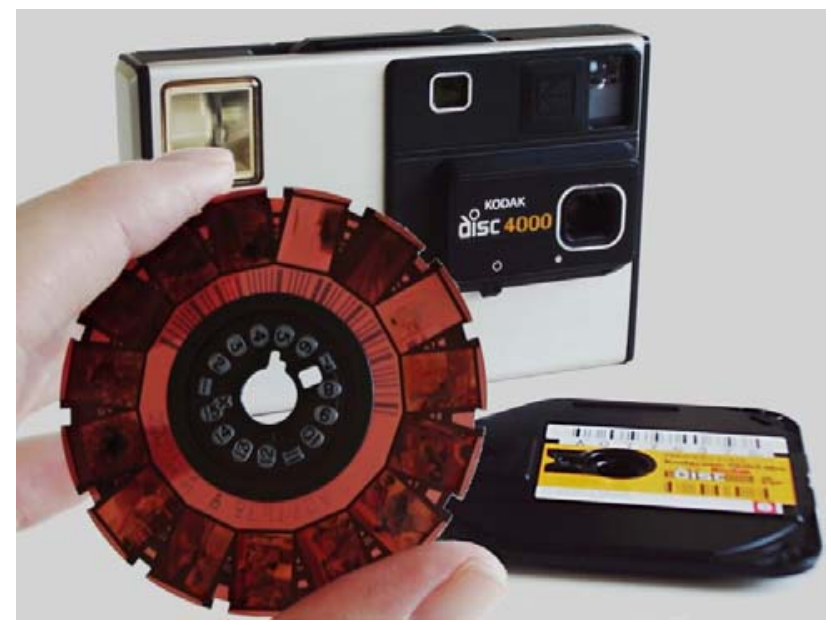


O sistema foi pensado tendo em vista a automação dos processos de revelação e copiagem nos laboratórios de foto acabamento e cada disco tinha 15 fotogramas de $8 \times 11 \mathrm{~mm}$. O sistema não chegou a se popularizar, tendo vida bastante curta.

A tabela abaixo mostra a área útil dos fotogramas nos formatos subminiatura e sua relação com a área do fotograma do padrão $35 \mathrm{~mm}$.

$\begin{array}{ccc}\text { Formato } & \text { Área útil }-\mathrm{mm}^{2} & \% \text { do Formato } 35 \mathrm{~mm} \\ 35 \mathrm{~mm} & 864 & 100 \\ 35 \mathrm{~mm} \text { Meio quadro } & 432 & 50 \\ 126 & 676 & 78 \\ 110 & 221 & 26 \\ \text { Disk } & 88 & 10\end{array}$

O tamanho cada vez menor dos negativos fazia com que a maioria dos fotógrafos considerasse as imagens pouco satisfatórias, devido à granulação e à falta geral de nitidez que provavelmente se devia em parte à baixa qualidade das objetivas usadas na maioria absoluta dos modelos mais populares.

Mas, havia ainda outro problema: a elevada escala de ampliação exigida mesmo para fazer cópias de dimensões modestas evidenciava em demasia riscos ou sujeiras existentes nos filmes, exigindo condições de limpeza e cuidados na manipulação que a maior parte dos laboratórios encontrava dificuldade para atingir. Mesmo contando com a fidelidade de certo número de aficionados, os formatos pequenos foram sendo abandonados. Já em meados da década de 1990, na última tentativa de criar um novo padrão analógico, o sistema APS usava um formato de 17 x $30 \mathrm{~mm}$ com $510 \mathrm{~mm}^{2}$ de área útil. Esse sistema usava trilhas magnéticas para gravar informações digitais nas margens dos filmes, mas acabou logo sendo atropelado pela rápida expansão dos sistemas digitais de fotografia. 
A transição para a fotografia digital.

A chegada da fotografia digital é um processo complexo que ocorre em muitas frentes diferentes e com velocidades variáveis.

Logo de início, um detalhe curioso é que o dispositivo básico para a fotografia digital, que é a matriz fotossensível conhecida pela sigla CCD (Charge Coupled Device) ou Dispositivo de Carga Acoplada, é em princípio um componente analógico. Nele a energia luminosa se transforma em cargas elétricas que são depois processadas para se obter um sinal elétrico que representa a imagem. O componente já existe há muito tempo e vem sendo empregado nos sistemas analógicos de televisão. E mesmo em circuitos fechados de televisão usados hoje para monitoramento de ambientes.

Os primeiros dispositivos tinham pouca resolução e preço muito elevado. Com o passar do tempo, simultaneamente os preços vão diminuindo e a resolução melhorando. Esse processo vai acontecendo de forma contínua, lenta inicialmente e vai se acelerando com o passar do tempo. Nesse processo, as diversas aplicações vão se aproximando e incorporando a tecnologia na medida em que a equação de custo e qualidade se torna viável.

Há basicamente duas classes de CCDs: os lineares em que a digitalização se faz por varredura unidirecional da imagem e os de matriz bidimensional que, usando uma superfície sensível para captar a imagem, constituem os sucedâneos eletrônicos dos filmes fotográfico. Os CCDs empregados nas aplicações analógicas estão nesta categoria.

Nas aplicações fotográficas pictóricas, a digitalização chega inicialmente em etapa posterior à captação, explorando filmes ou cópias sobre papel 
com o uso de dispositivos de varredura (scanners) para importar as imagens em aplicações informatizadas. É importante observar que os recursos de edição da fotografia digital começaram a ser usados no tratamento de imagens que tendo sido registradas sob forma analógica, só posteriormente eram digitalizadas.

Uma vez digitalizadas estava aberto todo um leque de recursos, mas para obter cópias físicas dessas imagens era preciso recorrer a dispositivos que utilizavam técnicas gráficas de impressão usando equipamentos que em sua quase totalidade não permitiam a impressão de tons contínuos, exigindo o uso de retículas para gerar os tons intermediários. A exceção era o processo por sublimação de corantes de uso limitado devido ao custo elevado.

Surgem scanners que podem ser acoplados em câmaras de chapas para permitir a captação digital diretamente. São dispositivos muito caros e que, devido ao tempo de varredura, não permitem a captação de imagens de objetos em movimento, de forma muito semelhante, diga-se de passagem, ao que ocorreu nos primórdios da fotografia analógica.

À medida que se aperfeiçoam os CCDs bidimensionais, surgem câmaras que permitem registrar diretamente as imagens como matrizes bidimensionais na forma de arquivos binários. É importante lembrar que essa matriz continua sendo bidimensional mesmo quando a informação armazenada se refere a vários canais de cores, pois ela representa apenas um plano, como no caso do filme ou da cópia analógica. 


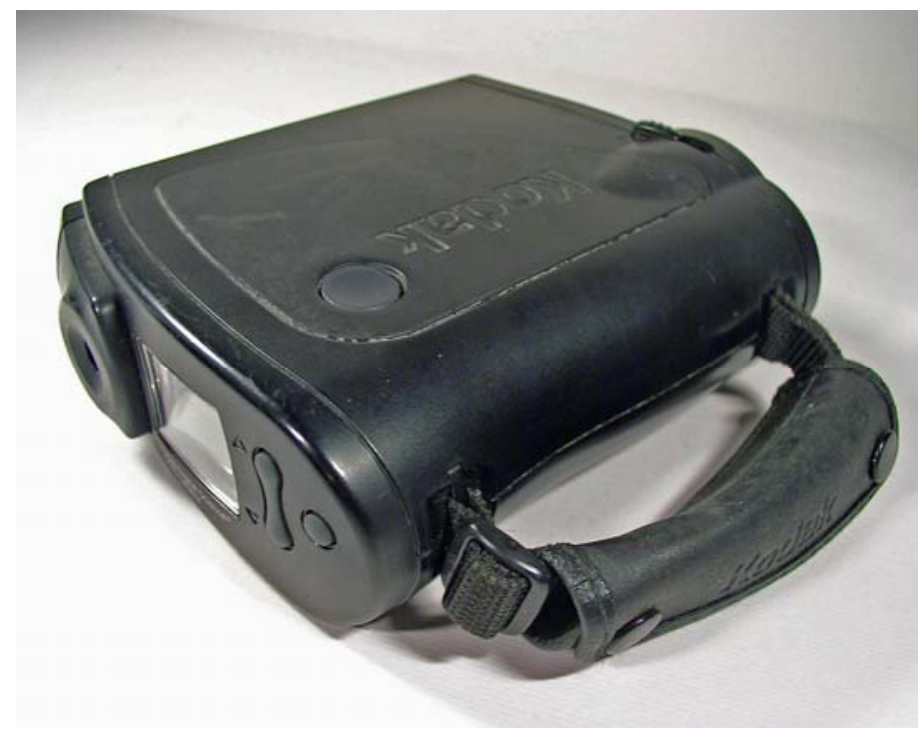

A partir do surgimento dessas câmaras e um pouco depois quando os preços começam a cair tornando-as mais acessíveis se inicia o fulminante processo de difusão que está em curso. Neste exato momento, pode-se dizer que praticamente todos os modelos disponíveis na praça, com a possível exceção de alguns poucos de preço muito baixo já apresentam resolução mais do que suficiente para oferecer resultados superiores aos das máquinas analógicas que ocupavam posição semelhante no mercado há cerca de 5 ou 6 anos atrás, e é perceptível o surgimento de uma tendência no sentido de incorporar recursos avançados, como estabilizadores de imagem, mesmo a modelos relativamente econômicos.

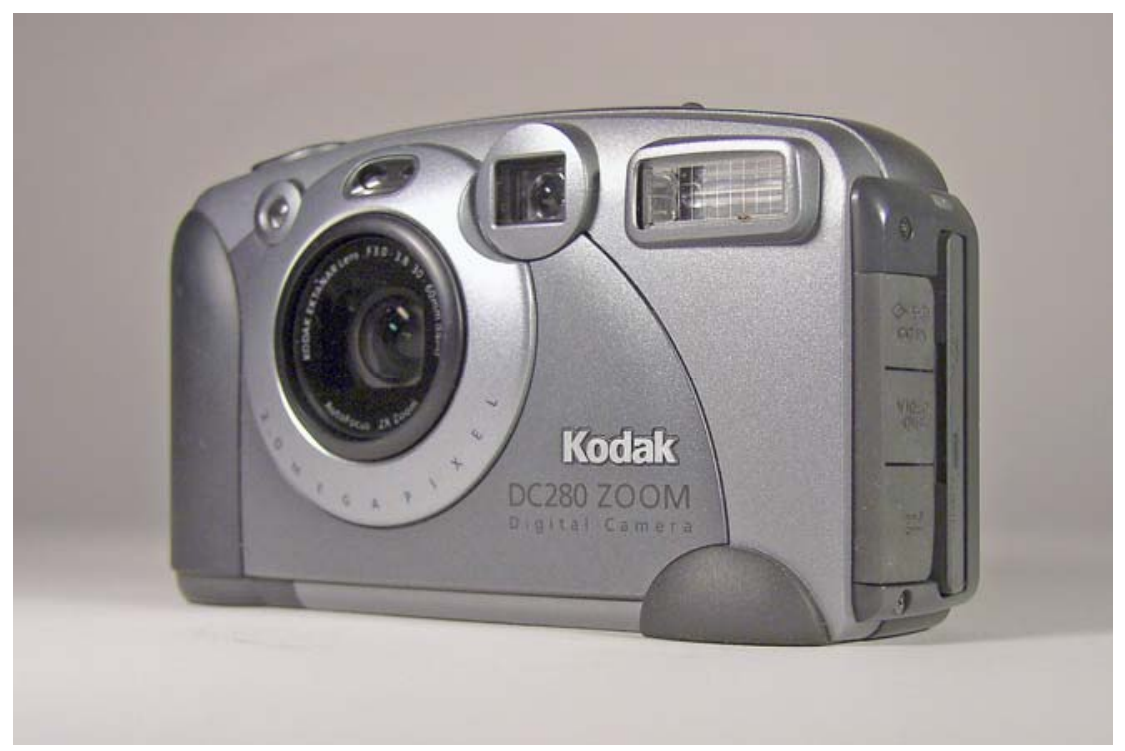


Os sistemas de visor constituem importante elemento das câmaras digitais e têm importância fundamental no modo como são operadas. Os dispositivos baseados na tecnologia de cristal líquido (LCD) têm hoje emprego praticamente universal. Diferente dos visores óticos tradicionais, nos quais a imagem se forma com a própria luz da cena, os visores eletrônicos são ativos, isto é, a energia luminosa da imagem vem da bateria que alimenta a câmara, enquanto a luz da cena fornece apenas a informação necessária para formar a imagem. Assim, é tecnicamente possível o visor exibir uma imagem até mais luminosa do que a própria cena.

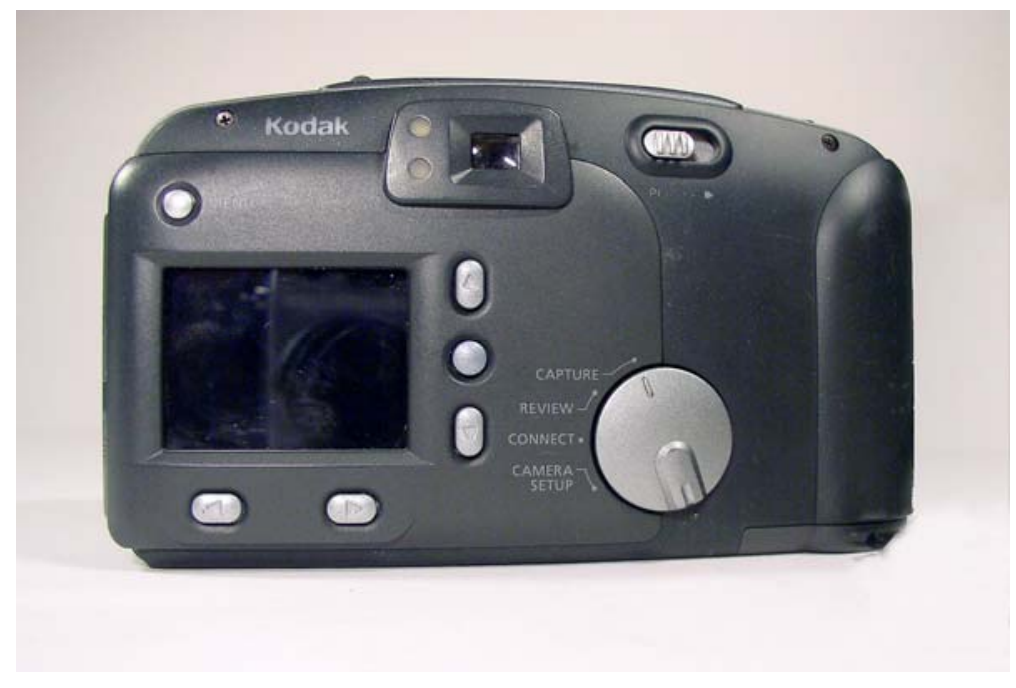

As primeiras câmaras digitais não usavam esse tipo de visor que tinha na época custo bastante elevado. Hoje, pelo contrário há modelos que não usam mais visores óticos de tipo clássico, mas tem até dois visores eletrônicos, um de pequenas dimensões, para ser usado próximo ao olho e outro maior para visualização a certa distância. Esta característica é responsável por uma das mudanças mais radicais no uso das câmaras digitais, pois representa a ruptura com o conceito tradicional que estabelecia certa identidade entre a posição da objetiva e o olho do fotógrafo. 
Os primeiros visores LCD eram bastante pequenos, principalmente em comparação com o tamanho das câmaras que eram bem maiores do que as atuais. É curioso observar que o aumento no tamanho dos visores ocorre junto com uma tendência de miniaturização das câmaras que acaba sendo limitada pelas dimensões dos mesmos. Há câmaras que, mesmo sendo menores do que um maço de cigarros, possuem visores que exibem imagens de $4,5 \times 6 \mathrm{~cm}$, equivalente aos das câmaras de formato médio que usam filmes tipo 120.

Em algumas modelos o visor é móvel permitindo ao fotógrafo controlar o enquadramento a partir de qualquer posição ao redor da câmara. É um requinte que, mesmo oferecendo inegável conforto na operação, representa aumento significativo de custo e introduz um elemento de fragilidade mecânica no equipamento.

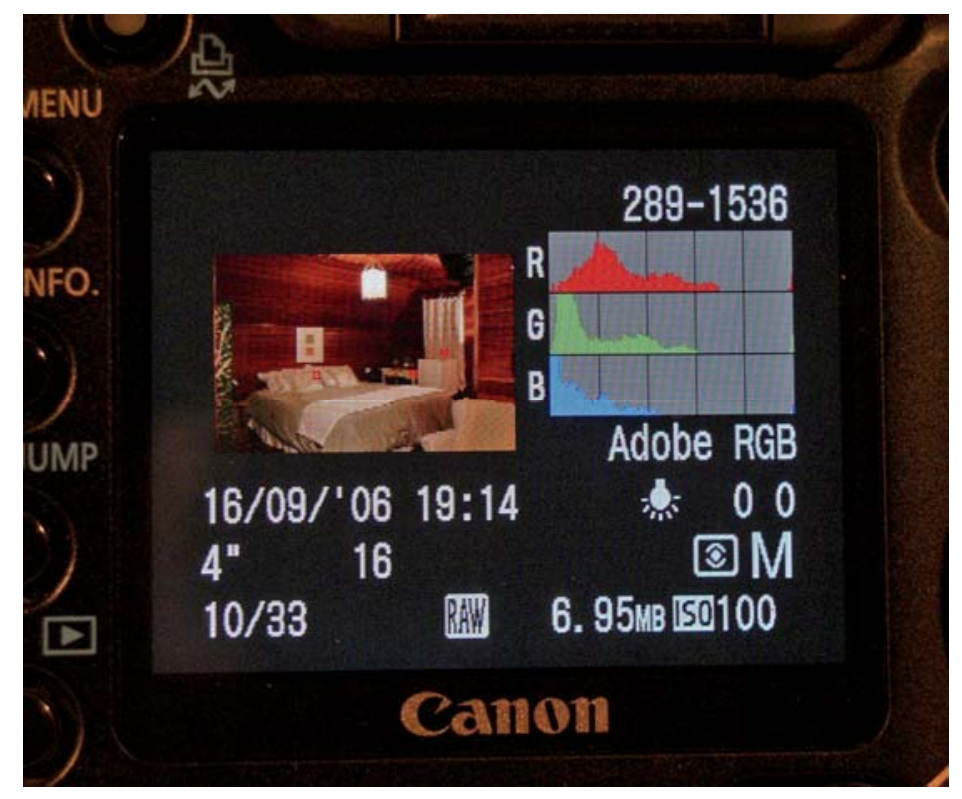

Como não poderia deixar de ser, todos eles permitem exibir, em sobreposição à imagem propriamente dita, informações para controle do equipamento como dados de focalização e exposição, zoom, situação de carga do flash e das baterias, espaço disponível na memória etc. 
O preço das memórias não voláteis utilizadas no armazenamento vem também caindo de forma contínua junto com o aumento de sua capacidade e com isso a autonomia de operação dos equipamentos.

Nos laboratórios de foto acabamento as cópias se fazem expondo papéis fotográficos em impressoras digitais e se chega à situação paradoxal em que a cópia final de uma foto pode ser hoje a única fase do processo em que se usa uma superfície sensível baseada no sistema fotoquímico de haletos de prata.

Chegamos aqui ao quadro atual dos dispositivos técnicos empregados na prática do processo fotográfico. Não se pode dizer que a tarefa esteja terminada, pois esse é um processo contínuo. Mas, neste momento em particular, visualizamos um quadro em que ocorrem simultaneamente uma expansão muito rápida dos sistemas de fotografia digital e o abandono praticamente total de todos os sistemas anteriores. 
CAPITULO 3

Tempo 


\section{Tempo}

O tempo é assunto inevitável quando se pensa no processo fotográfico. Ele já está na equação básica $\mathrm{E}=\mathrm{I} \times \mathrm{T}$ que quantifica a energia luminosa que produz o registro fotográfico (E) como produto da intensidade da luz (I) pelo tempo de exposição.

Em termos operacionais esses parâmetros são controlados por dois dispositivos distintos, o diafragma que permite ajustar a intensidade da luz e o obturador que controla o intervalo de tempo durante o qual a luz age sobre a superfície sensível.

O obturador é uma válvula de luz que ajusta não apenas a duração do intervalo de tempo, mas também a localização desse intervalo dentro da escala cronológica.

No período de surgimento da fotografia o tempo era visto essencialmente como um problema por ser um fator limitante no registro das imagens. $\mathrm{O}$ primeiro registro fotográfico feito por Niépce em 1826 levou oito horas para ser feito. Ao longo do século XIX esse tempo foi sendo reduzido e em 1900 era possível registrar imagens em apenas frações de segundo.

Quando esse tempo atinge um valor suficientemente pequeno para escapar aos limites da percepção, ele praticamente desaparece e surge a idéia de que a fotografia é um registro "instantâneo". Essa idéia é bastante simplista, mas pelo menos serve para deixar claro que estamos falando do tempo em seu conceito físico. Basta uma rápida consulta a qualquer dicionário para se encontrar algo ao redor de quinze acepções para a palavra. "Instante" e "momento" não ficam muito atrás com cerca de cinco acepções cada. Vamos por enquanto continuar usando o conceito físico de tempo. 
$\mathrm{Na}$ equação que citamos acima a variável tempo se refere à duração do intervalo durante o qual a superfície sensível fica exposta à energia luminosa, submetida, portanto à sua ação. A ação da luz produz uma alteração de estado no material sensível, ou em termos físicos, realiza um trabalho. Mas, concluído esse trabalho, a foto não está pronta. Para que isso aconteça, muitas outras operações serão ainda necessárias. Em outras palavras, há ainda muito trabalho pela frente. E pensando bem, não só pela frente. Antes do momento em que a luz tivesse a oportunidade de modificar a estrutura da chapa sensível, muita coisa teve que acontecer como preparação, até se chegar à possibilidade de fazer o registro.

Mesmo nada mais sabendo ainda sobre essas etapas, fica evidente que além, e aquém, do tempo de exposição, outros tempos se relacionam com ele e que conjuntamente estabelecem um tempo maior que se associa ao processo como um todo, de fazer a fotografia. Mesmo assim, sendo apenas uma parte bem pequena do processo, não só o momento da exposição parece ser importante o bastante para ser considerado o mais importante, como de forma aparentemente paradoxal, essa importância aumenta quando ele diminui e tende a desaparecer.

Por essa lógica o aumento do tempo diminui sua importância. Uma possível explicação para isso se encontra na idéia de que a duração, como oposição ao instante representa uma limitação a ser superada.

No ensaio "O tempo e a originalidade da fotografia moderna" Maurício Lissovsky, declara já no início que, em seu trabalho, a idéia de tempo se refere ao "instantâneo", que é usado como referência para definir a fotografia "moderna", em oposição aos registros feitos em tempos nos quais a baixa sensibilidade das películas exigia tempos longos de exposição, estabelecendo que 
"somente na década de 1870, com a utilização de substâncias mais sensíveis $e$, conseqüentemente, obturadores mais rápidos, a fotografia torna-se realmente instantânea." (LISSOVSKY, 2003:142s)

Partindo da idéia de que,

"no início da fotografia, o tempo se fazia presente apenas como um ingrediente problemático do registro", (id.)

a evolução para o instantâneo, estabelece a hipótese de que

"a origem da fotografia - ao menos da fotografia moderna, se admitimos esta concessão historicista - foi sua relação com o tempo. Foi o modo como, aceitando o tempo como o invisível da imagem fotográfica, permitiu que ele a atravessasse de múltiplas maneiras." (id)

Retornando ao ensaio, Lissovsky coloca a questão da existência, ou não, do "instante" e analisa o conceito de tempo de Bérgson mostrando que, na concepção do filósofo

"o instante não é uma fotografia, mas um fotograma - o fotograma de uma película cinematográfica." (LISSOVSKY, 2003:142s)

e que, para Deleuze, retomando as teses de Bergson, o instante também é um fotograma. 
A identidade entre o instante e o fotograma mostra claramente a origem "cinematográfica" do conceito, mas veremos que ela é importante no ambiente das próprias imagens "estáticas".

Voltando ao ensaio de Lissovsky, ele prossegue mostrando a construção de um "bergsonismo descontínuo" que se estabelece nos ensaios da década de 1930, "A Intuição do instante" e "Dialética da Duração", escritos por Gaston Bachelard e diz que:

"Enquanto a duração bergsoniana seria correlata da ação, o instante representaria o ato. Deste ato dependeria toda originalidade, como da pancada que faz vibrar o couro, no som de um instrumento de percussão: uma força infinitamente grande que se desenvolve em um tempo infinitamente curto". (LISSOVSKY, 2003:142s)

Surge aqui claramente uma idéia de COMPRESSÃO ou CONDENSAÇÃO com a qual iremos trabalhar oportunamente.

Lissovsky mostra simpatia com o esforço de Bachelard, mas ressalva aspectos que o incomodam, em particular a

"assimilação do instante primordial a um ato de "decisão", como se este não pudesse ser precedido pela intensa agonia da indecisão. Afinal, que melhor exemplo de experiência da duração do que a indecisão? Dura-se na indecisão; na indecisão o tempo pesa." (LISSOVSKY, 2003:142s) 
Considerando insatisfatórias, para pensar o instantâneo fotográfico, tanto as idéias de Bachelard quanto as de Deleuze, Lissovsky diz que sua

\author{
"intuição do instante" é a de que é possível \\ conciliá-lo com a experiência da duração". \\ pensando o instante imanentemente e não \\ com uma exterioridade que se abate sobre o \\ contínuo." (LISSOVSKY, 2003:142)
}

Par Lissovsky, a condensação do tempo se associa à idéia da ESPERA e ele estabelece essa afirmando dizendo que:

"a origem da fotografia, ... é este refluir do tempo - refluir que sempre esteve presente em toda imagem "fixa". Por meio da espera, o fotógrafo procura imprimir na imagem o tempo que se ausenta. Ela é a duração própria do ato fotográfico e o modo como os fotógrafos facultam ao instante o seu advento. Na duração da espera, o tempo devém instante." (LISSOVSKY, 2003:142s)

O autor diz então que é preciso demonstrar que existe um instante, começando pela recusa em aceitar que não exista o "instante" a partir da premissa de que a exposição fotográfica, por mais curta que seja, tem uma duração física finita e estabelecendo a "discernibilidade", baseada em limiares relativos de percepção temporal, para definir a idéia de instantâneo, de forma essencialmente semelhante aos modelos usados para estabelecer os chamados "círculos de confusão" nos cálculos de nitidez espacial das tabelas de profundidade de campo. A forma usada na construção estabelece uma ligação entre o conceito físico de tempo e seu aspecto perceptivo. $\mathrm{O}$ instante é então todo o tempo físico 
suficientemente curto para parecer que não existe, pelo menos do ponto de vista perceptivo.

Isso nos leva para o domínio da percepção. E no caso da fotografia, especificamente para a percepção visual. Como o tempo é percebido na fotografia? A percepção do tempo se dá pela exibição estática de coisas que estariam em movimento, ou seja, como um congelamento do tempo. Nesse sentido, o instantâneo precisa do movimento. A fotografia de uma natureza morta não é instantânea independente do tempo de exposição que tenha sido usado para registrá-la. O instante é uma conjugação do movimento com um tempo que o imobiliza e se atesta pelo "aprisionamento" da forma estática dos objetos móveis. A junção dessas duas grandezas pode permitir certa analogia com um modelo físico de energia, onde esta pode ocorrer apenas em uma forma como também se transformar de uma para outra forma. Nessa analogia, o instante representa uma mudança da energia cinética do tempo em movimento para a energia potencial do tempo aprisionado.

Voltando ao ensaio de Lyssovsky, ele diz que

"entre o surgimento da tecnologia do instantâneo e o nascimento da fotografia moderna - cuja condição técnica de possibilidade é exatamente o instantâneo passam-se praticamente quarenta anos. Tal intervalo pode ter sido necessário para que esta tecnologia finalmente se naturalizasse. Para que o "problema do tempo" caísse no esquecimento e a miragem do movimento perdesse seu encanto." (LISSOVSKY, 2003:142s) 
E mesmo admitindo que

"A intensidade com que fotógrafos como Muybridge e Jules- Marey dedicaram-se às suas cronofotografias (que, de fato, deveriam chamar-se 'dromofotografias'), constituindo seqüências de movimentos humanos e animais - e a curiosidade que despertavam estas imagens - marcam a época.“ (LISSOVSKY, 2003:142s),

Situa, com propriedade, esses trabalhos em um período pré-moderno.

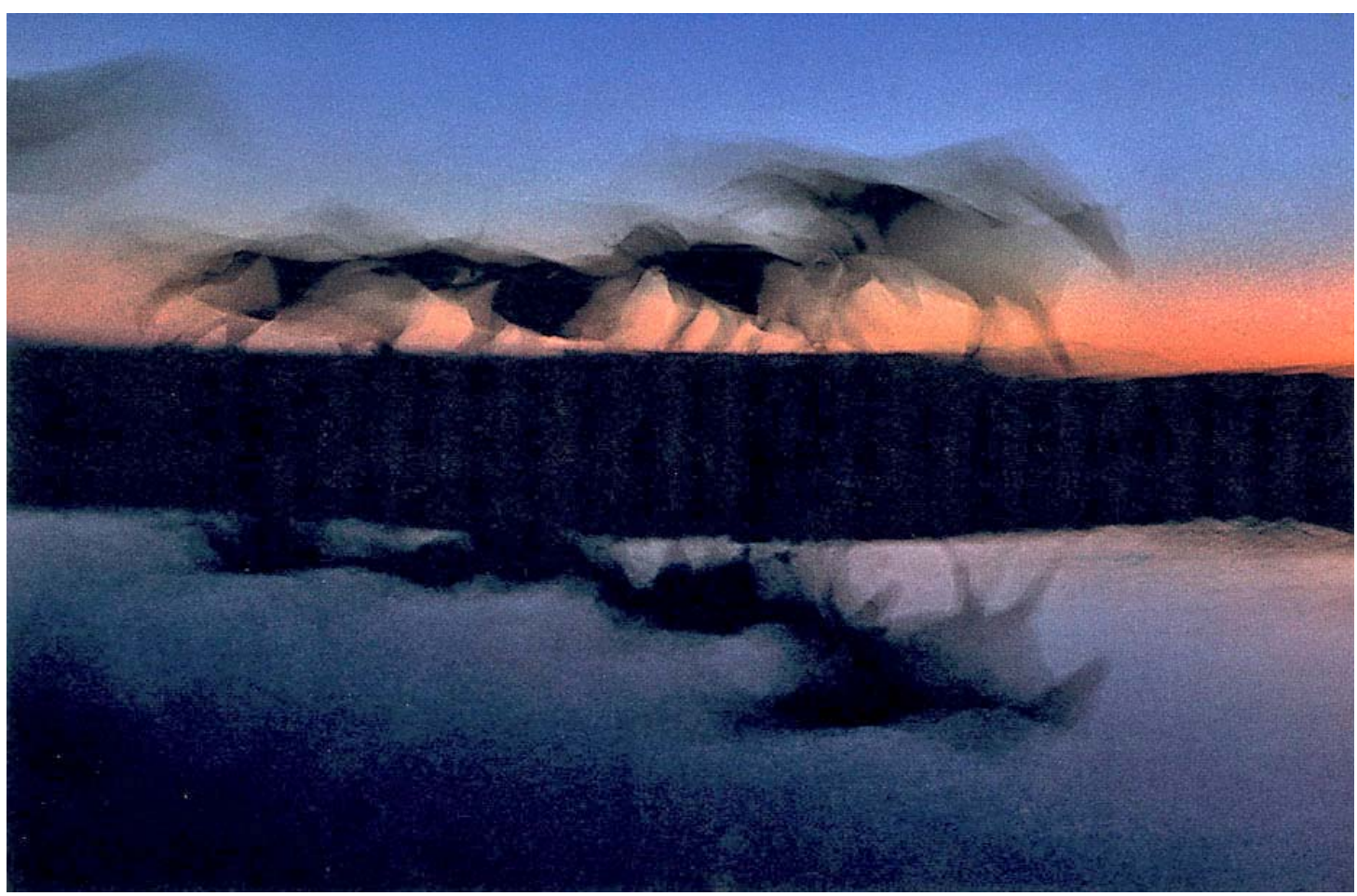

A fotografia cima, de Ernst Hass foi produzida na década de 1960 e se por um lado remete às imagens de Muybridge e de Marey, por outro é de natureza inequivocamente diversa. Pode estar mais próxima das imagens de Lartigue, mas não se ocupa essencialmente de anamorfose. Usando a 
analogia que estabelecemos acima, nela encontramos, simultaneamente a energia cinética e a potencial, sendo uma imagem exatamente da sua transformação. Mesmo não atendendo à exigência de desaparecimento do tempo, ela se relaciona com um instante, um pouco longo talvez para o critério de Lyssovsky, mas moderno mesmo assim.

Seja como for, estamos tratando sempre apenas de um tempo físico que se relaciona também com apenas uma única imagem. É a esse instante, curto ou longo, não importa, que Roland Barthes se refere ao dizer que o fulcro da imagem fotográfica é o "isso foi". O instante é portanto o "quando" que se associa ao "isso foi".

Mesmo sendo apenas um ponto notável tem uma existência própria tão marcante que ao estabelecer um corte definido na linha do tempo, cria não apenas duas regiões contíguas, um "antes" e um "depois", mas ainda uma própria que mesmo sendo pequena, tendendo a zero muitas vezes, tem importância crucial que deriva exatamente de suas dimensões mínimas.

Para compreendê-lo será preciso, contudo ir além desse instante e procurar analisar a fotografia não apenas na sua forma final acabada, que mostra evidentemente o tempo do "isto foi", Será preciso olhar também aquilo que aconteceu até se chegar ao "quando" do isso foi, de forma a poder chegar até "o que" e "como" isso foi. Será precis pensar a fotografia não como resultado mas como processo.

Lyssovsky inicia já esse questionamento, mas aplica sobre a linha do tempo uma lente de aumento bastante forte. Consegue assim obter profundidade na visão e compreensão dos momentos que antecedem ao disparo do dobturador, a espera. Mas será preciso afastamento um pouco maior para buscar a compreensão do processo, inclusive para deslocar o tempo de registro da foto mais para o centro do espaço. Com efeito, 
Lyssovsky, ao considerar que essa ação tudo resolve, aceita que nada mais de importante acontece depois dela e assim faz com que ela seja, mais do que um ponto de ruptura, um efetivo ponto final.

Além do maior afastamento do objeto, será preciso incluir na análise outras camadas para incluir concepções de tempo que vão além do conceito físico com que trabalhamos até agora. 
CAPITULO 4

\section{Origens}


Philippe Dubois, em "O ato fotográfico" de 1990, historiando as análises do processo fotográfico, diz que, para André Bazin,

"A característica fundamental da imagem, fotográfica deve ser procurada "não no resultado, mas na gênese". Se quisermos compreender o que constitui a originalidade da imagem fotográfica, devemos obrigatoriamente ver o processo bem mais do que o produto $e$ isso num sentido extensivo: devemos nos encarregar não apenas no nível mais elementar, das modalidades técnicas de constituição da imagem (a impressão luminosa), mas igualmente, por uma extensão progressiva, do conjunto dos dados que definem, em todos os níveis, a relação desta com sua situação referencial, tanto no momento da produção (relação com o referente e com o sujeito-operador: o gesto do olhar sobre o objeto: momento da "tomada"), quanto no da recepção(relação com o sujeitoespectador: o gesto do olhar sobre o signo: momento da "retomada": da surpresa ou do equívoco).” (BAZIN, in DUBOIS, 1990:85)

Bazin ressalta aqui a importância da relação da imagem com seu referente, contextualizada no processo como um todo. Dubois sintetiza afirmando que 
“...com a fotografia não nos é mais possível pensar a imagem fora do ato que a faz ser." (DUBOIS, 1990:15)

E prossegue em sua análise ressaltando que

"Existe uma espécie de consenso de
princípio que pretende que o verdadeiro
documento fotográfico "presta contas do
mundo com fidelidade"“. Foi-lhe atribuída
uma credibilidade, um peso de real bem
singular. E essa virtude irredutível de
testemunho baseia-se principalmente na
consciência que se tem do processo
mecânico de produção da imagem
fotográfica, em seu modo específico de
constituição e existência: o que se chamou
de automatismo de sua gênese técnica."
(DUBOIS, 1990:25)

Para Dubois, é possível agrupar em três épocas o estudo das diversas tendências surgidas, ao longo da história da fotografia, na análise desse princípio de realidade estabelecido entre a imagem fotográfica e seu referente:

1- a fotografia como espelho do real (o discurso da mimese);

2- a fotografia como transformação do real (o discurso do código e da desconstrução);

3- a fotografia como traço de um real (o discurso do índice e da referência). 
$\mathrm{Na}$ primeira delas, atribui-se à semelhança existente entre a foto e o referente, o efeito de realidade. $\mathrm{Na}$ segunda, superando a idéia da fotografia como um espelho, o princípio de realidade foi classificado como mero efeito e substituído pela idéia de um instrumento de transposição, socialmente codificado como a língua, com potencial até de transformação do real. Finalmente na terceira, ultrapassando a idéia de "efeito de realidade", busca-se, com base em conceitos estabelecidos por Ch. S. Peirce, mais especificamente as noções de índice (contrapondo-se às de símbolo e ícone) uma lógica fundamental da imagem fotográfica.

Dubois observa que a fotografia provocou vivas reações desde seu surgimento e discutindo as questões da fase inicial, a do discurso da mimese, diz que

"Embora comportasse declarações muitas vezes contraditórias e até polêmicas, o conjunto de todas essas discussões, de toda essa metalinguagem nem por isso deixava de compartilhar uma concepção geral bastante comum: quer se seja contra, quer a favor, a fotografia nelas é considerada como a imitação mais perfeita da realidade. $E$, de acordo com os discursos da época, essa capacidade mimética procede de sua própria natureza técnica, de seu procedimento mecânico, que permite fazer aparecer uma imagem de maneira "automática", "objetiva", quase "natural" (segundo tão-somente as leis da ótica e da química), sem que a mão do artista intervenha diretamente. Nisso, essa imagem se opõe à obra de arte, produto do trabalho, 
do gênio e do talento manual do artista." (DUBOIS, 1990:27)

É interessante observar que tanto para os críticos quanto para os entusiastas, indo além da concordância sobre a "imitação perfeita da realidade", há coincidência também na clivagem funcional, arte de um lado e técnica do outro.

As avaliações todas dessa primeira época, situada por Dubois, colocam a fotografia como uma sucessora automatizada das técnicas tradicionais, mas mesmo reconhecendo a maior perfeição da imitação, ao insistir na superioridade da arte, ignoram o aspecto mais importante da funcionalidade do meio: a credibilidade. A esse respeito, Dubois cita Baudelaire, que afirmava:

"É portanto necessário que ela (a fotografia) volte ao seu verdadeiro dever, que é o de servir ciências e artes, mas de maneira bem humilde, como a tipografia e a estenografia, que não criaram nem substituíram a literatura. (...) Mas se lhe for permitido invadir o domínio do impalpável e do imaginário, tudo o que só é válido porque o homem lhe acrescenta a alma, que desgraça para nós." (BAUDELAIRE, in DUBOIS, 1990:29)

William Crawford, em sua obra "The Keepers of Light" toca nessa questão quando coloca na origem de seu trabalho sobre fotografia, os conceitos de William M. Ivins na obra "Gravuras e comunicação visual" de 1954. Segundo ele, Ivins mostrava que, 
"historicamente, a gravura não era praticada como uma forma de arte completa em si mesma, como viria a ser praticada hoje, em suas técnicas tradicionais, mas como uma forma de distribuir informação visual."(IVINS, in CRAWFORD, 1979:1)

Crawford mostra que para Ivins, mesmo sendo sua abordagem estritamente funcionalista, essa posição nada tinha de humilde, mas era na verdade sua maior força, ao afirmar que

"não se pode esperara compreender a significação da fotografia a menos que se compreenda a natureza do problema que ela resolveu. Esse problema era o $d a$ comunicação visual acurada, um problema com que muitas gerações se defrontaram, sem muito sucesso." (CRAWFORD, 1979:5)

E prossegue, afirmando que

"a maior conquista da fotografia foi tornar possível a comunicação através de "declarações pictóricas exatamente repetíveis", sem as distorções da sintaxe linear." (id)

Ivins achava que a fotografia não tinha sintaxe e nisso se aproximava, por exemplo, da opinião de Roland Barthes para quem, conforme cita Dubois, 
"para passar do real à sua fotografia, não é absolutamente necessário recortar esse real em unidades e constituir essas unidades em signos substancialmente diferentes do objeto que dão para ler. Entre esse objeto e sua imagem, não é em absoluto necessário dispor de uma etapa, ou seja, um código. Decerto a imagem não é o real, mas(...) é precisamente essa perfeição analógica que, diante do senso comum, define a fotografia. Assim, aparece a condição particular da imagem fotográfica: é uma mensagem sem código." (BARTHES, in DUBOIS, 1990:36)

Crawford admite que essa posição de Ivins, já em 1979, seria de difícil aceitação, mas reconhece nela a importância de ter percebido que,

"Através das quebras feitas pela fotografia torna-se possível ver os lugares mais distantes, muito além do campo físico da visão e até ver momentos passados congelados no tempo, tudo isso sem as distorções da sintaxe linear. Nosso poder fotográfico sobre espaço e tempo nos faz fundamentalmente diferentes, no âmbito da consciência, dos nossos ancestrais préfotográficos, cujo horizonte visual era limitado e cujos momentos passados ficavam para sempre perdidos do olhar. A fotografia irrompeu através do limite em que se achavam confinadas até então, as 
experiências visuais críveis.” (CRAWFORD, 1979:5)

Prosseguindo, Crawford vai tratar de estabelecer as bases de sua sintaxe fotográfica, através de uma analogia dizendo que :

"Quando usamos palavras para descrever um objeto, as possibilidades são infinitas; não há restrições quanto ao número de declarações que podemos fazer. A propósito de um edifício, podemos dizer " $E$ um edifício grande" ou, de forma mais erudita, "É uma estrutura neoclássica de dimensões consideráveis". Na aparência, as duas afirmativas são diferentes, mas por trás disso, ambas seguem as mesmas regras sintáticas. Por isso, as afirmações são infinitas apenas no mesmo sentido estrito em que consideramos os pontos que estão em um segmento de linha que vai de A até B. Pode haver um infinito número de pontos, mas a linha, ela mesma, é finita. Quando fotografamos um objeto, nossas possibilidades são infinitas. Podemos passar a vida inteira fotografando o edifício sob diferentes ângulos e sob diferentes condições de luz e as imagens serão tão diferentes quanto as declarações que falamos." (CRAWFORD, 1979:6) 
Prossegue, questionando que

“... dito isto, há alguma analogia útil que possamos descobrir entre falar sobre o edifício e fotografá-lo?

Há regras "sintáticas" de estrutura para o modo como transformamos objetos em fotografias, regras que forçam as infinitas possibilidades a cair ao longo de uma linha finita, da mesma forma como há regras para o modo como transformamos conceitos em declarações?” (id)

Alertando que a forma como se responde a essa questão tende a determinar o modo como se estuda a história da fotografia, Crawford conclui, definindo que

"há sim uma estrutura sintática para a "linguagem" da fotografia e de que ela vem não do fotógrafo, mas das relações químicas, óticas e mecânicas que tornam possivel a fotografia." (id)

E prossegue argumentando que

“... o fotógrafo pode fazer apenas aquilo que a tecnologia disponível naquele momento lhe permite fazer. Todos os tipos de convenções artísticas e aspirações pessoais podem influenciar um fotógrafo, mas apenas até onde a tecnologia permite. No fim de tudo, a fotografia é uma constante batalha 
entre a visão e a tecnologia. O gênio é constantemente frustrado e revigorado pela máquina." (id)

Para exemplificar, mostra a foto abaixo, feita em Paris na década de 1850 , comentando que o

“... resultado das longas exposições necessárias com a sintaxe dos daguerreótipos e antigos processos de placas úmidas é que o mundo urbano chega até nós virtualmente despovoados. Vemos muito pouco da atividade normal das ruas. As pessoas que efetivamente vemos ou pararam para posar ou permaneceram estáticas por acaso. Com freqüência vemos apenas os fantasmas semitransparentes de pessoas que se moviam rápido demais para serem registradas completamente, mas não o suficiente para desaparecer totalmente. $O$ mesmo ocorria com os veículos em movimento." (CRAWFORD, 1979:11-12) 


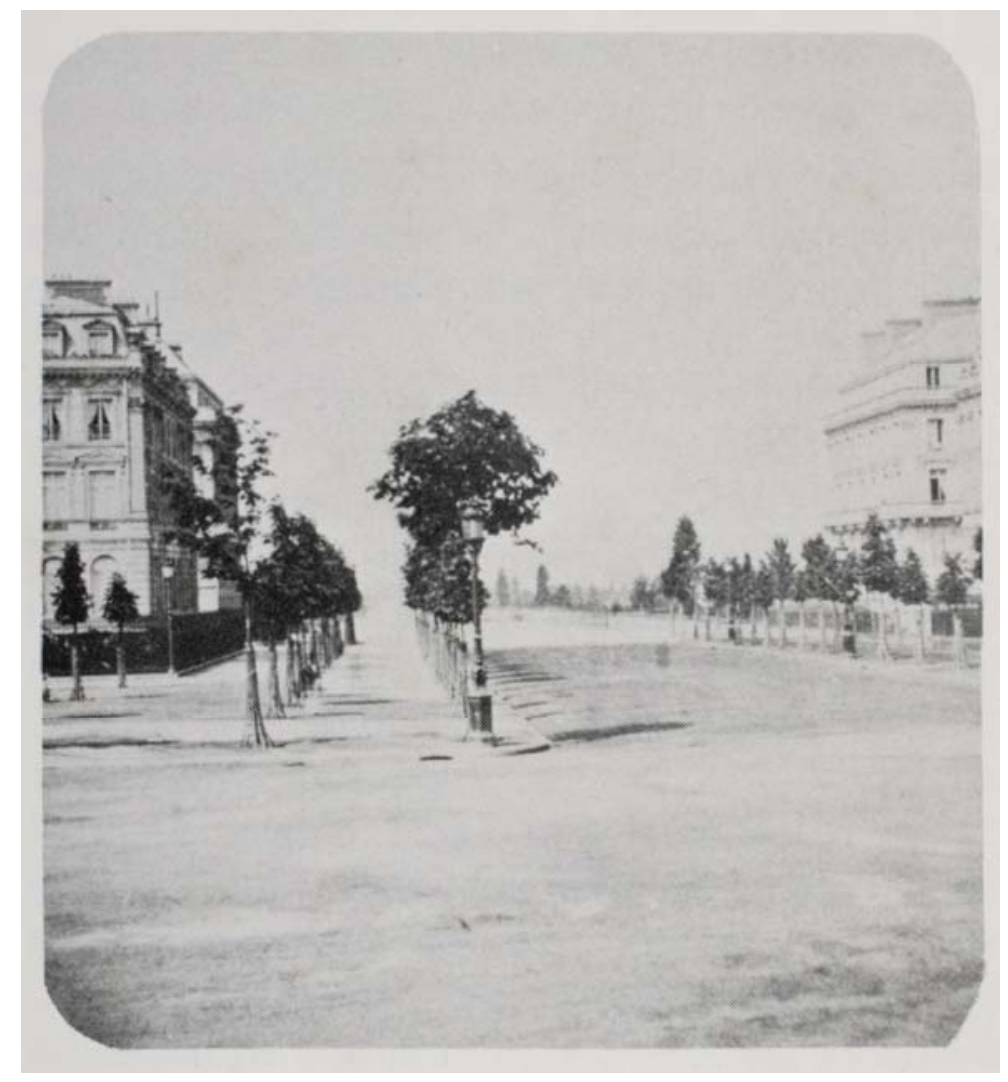

Crawford,W. 1979:11

Estabelecendo termo de comparação, Crawford mostra esta outra imagem abaixo, feita cerca de 10 anos depois, e acrescenta que

“... as primeiras fotografias "instantâneas” de ruas, feitas esporadicamente a partir de 1850, mas feitas em quantidade apenas depois de 1859, foram recebidas com contentamento e até alívio. Elas representaram um salto quântico nos potenciais sintáticos da fotografia porque elas começaram a mostrar como a cidade parecia "em uso", aspecto em que as fotografias anteriores a 1859 quase sempre falhavam." (id) 


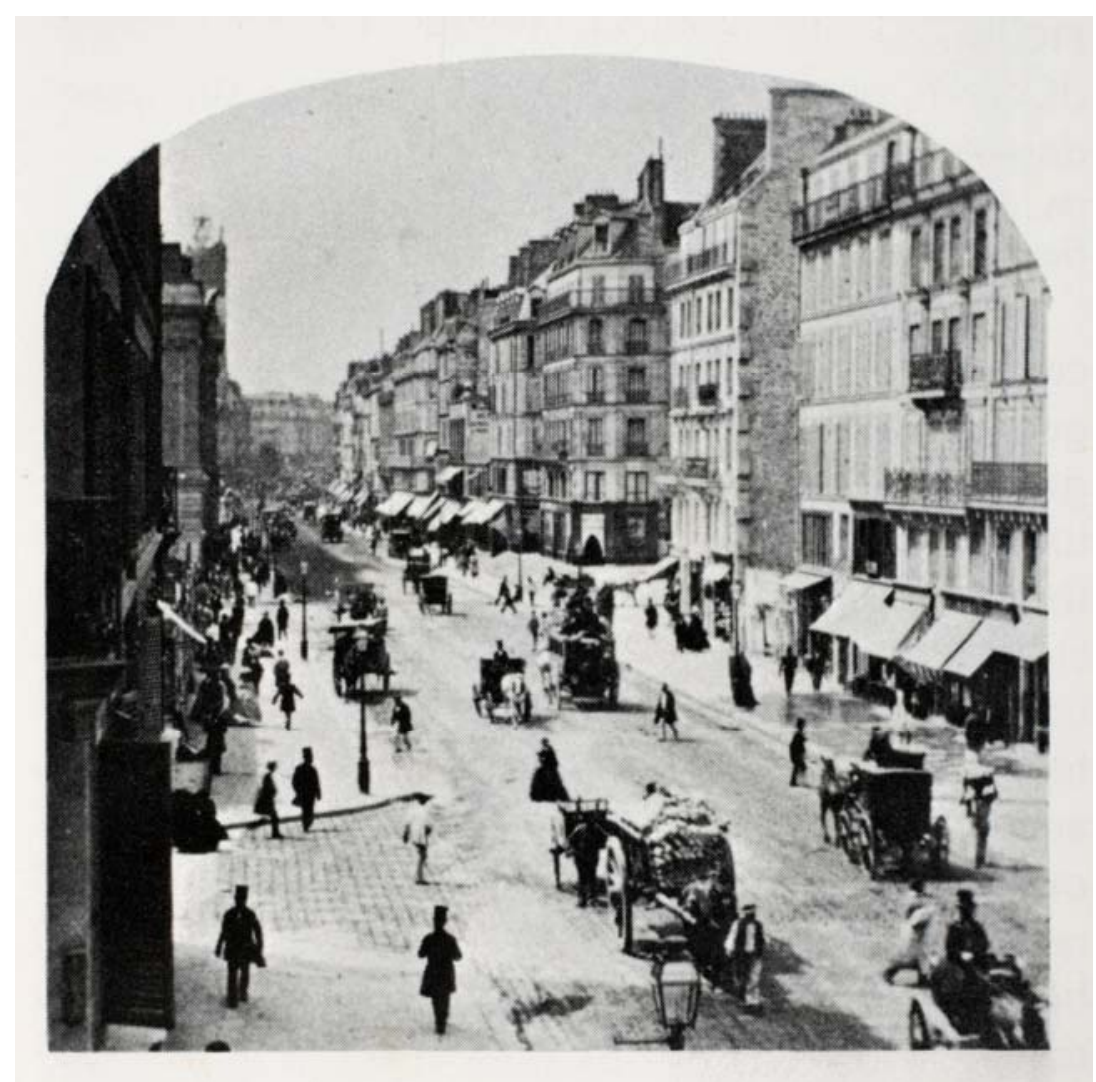

Willian England in Crawford,W. 1979:12

A idéia de falha está presente no comentário de Crawford, mostrando que a questão do tempo, enquanto limite, havia sido superada. Mas, diferente de Lissovsky, a superação não implica uma separação, mas apenas uma expansão dos limites. Ou seja, o que antes era um limite impeditivo, passa agora a ser recurso opcional de sintaxe, sendo apenas recolocado e não excluído.

Assim, ele apenas constata e admite sem juízos de valor que

"Antes das exposições "instantâneas" (ao redor de um décimo de segundo, conforme registros da época), (...) fotógrafos frequentemente registravam cenas de rua produzidas completamente em estúdio, com 
as pessoas posando na frente de painéis pintados (...e) se alguém quisesse fotografar a ação das ruas era preciso fazer as pessoas posarem ficando em posições que simulavam o movimento, como Charles Nègre fez em 1851",

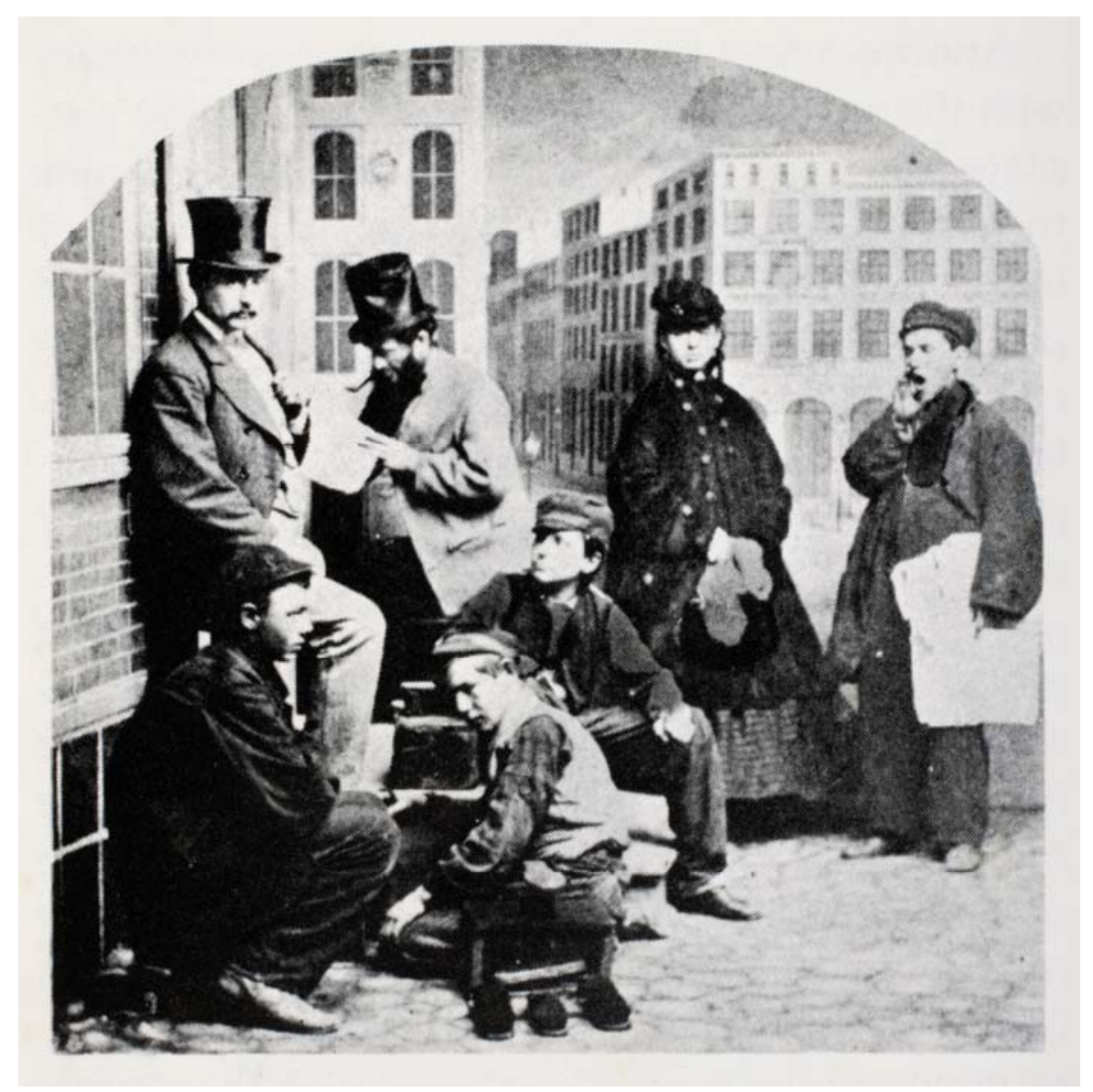

Crawford,W. 1979:12

A imagem abaixo usada para ilustrar como a sintaxe é um fardo a ser carregado para poder usar os recursos que ela oferece demonstra que para Crawford., parafraseando Ortega Y Gasset, o fotógrafo é ele mesmo e sua sintaxe. 


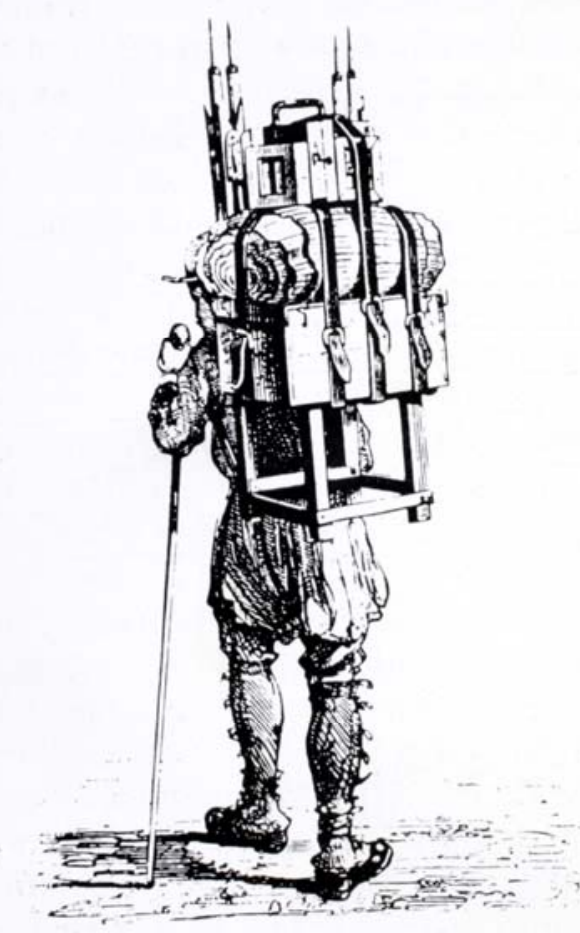

FIG. 4

A wet-plate photographer carrying his syntax on his back.

Crawford,W. 1979:7

A abordagem de Crawford, inspirada como é no modelo de Ivins, traz consigo forte carga funcionalista. Isso poderia ser um elemento limitante não fosse o fato de situar-se ela no nível mais básico do processo, e sendo assim permanecer, sem perder sua validade, como substrato, sobre o qual, outras camadas, menos físicas e mais abstratas, podem se estabelecer. Isso se evidencia quando ele ressalva que

"Até agora, pouco se falou sobre a contribuição do fotógrafo, parecendo até que a fotografia era inteiramente um exercício técnico. Essa ênfase não é ponderada, mas o risco foi assumido para mostrar que sempre que um fotógrafo encontra uma solução para um problema 
estético ele teve que resolver um problema técnico subjacente. Uma solução sustenta e influencia a outra. Claro que o fotógrafo é infinitamente mais interessante do que a máquina fotográfica, bem como as coisas que ele captura usando essa máquina. Mas, a menos que se entenda o modo como a máquina o limita nunca se vai saber realmente o quanto o fotógrafo é interessante, pois não serão percebidos os compromissos que ele teve que assumir para conseguir fazer sua visão chegar até o papel." (CRAWFORD, 1979:11-12)

Antes, porém de chegar à discussão da prática do processo, vamos estabelecer mais algumas considerações conceituais que servirão como ferramenta nesse trabalho.

Dubois considera que as análises que se mostram atualmente mais sérias e minuciosas, são as empreendidas pelos teóricos que se inspiram nas elaborações semióticas de Ch. S. Peirce e de forma mais específica em sua noção de índice, que relacionou já em 1895 à fotografia.

"As fotografias, e em particular as fotografias instantâneas, são muito instrutivas porque sabemos que, sob certos aspectos, elas se parecem exatamente com os objetos que representam. Porém, essa semelhança deve-se na realidade ao fato de que essas fotografias foram produzidas em tais circunstâncias que eram fisicamente 
forçadas a corresponder detalhe por detalhe à natureza. Desse ponto de vista, portanto pertencem à nossa segunda classe de signos: os signos por conexão física (indice)". (PEIRCE in DUBOIS, 1990:49)

Dubois considera que estão já aqui lançadas

“... as primeiras balizas de uma abordagem teórica do realismo fotográfico que ultrapassa o obstáculo epistemológico que é a questão da mimese. Vê-se que, para fundamentar sua definição, ele leva em consideração não o produto icônico concluído, mas o processo de produção do mesmo, anunciando dessa maneira Bazin e sua "gênese automática"." (id.)

Mas, diferente de Bazin, Pierce irá centrar sua atenção nas implicações semióticas relacionadas com o conceito de índice do que nas decorrências estéticas como as questões da objetividade ou da naturalidade.

Começando pela natureza técnica do processo, o princípio fundamental do registro luminoso, como traço ou depósito, se coloca na categoria dos signos em que estão também a fumaça (indício de fogo) ou a cicatriz (marca de um ferimento), agrupados pelo fato comum de sofrerem efetivamente ação de seu objeto. Mais adiante, Dubois detalha que o fundamento da categoria dos signos é a conexão física entre o índice e o referente, explicitada por Pierce na seguinte forma: 
"Chamo de índice o signo que significa seu objeto somente em virtude do fato de que está realmente em conexão com ele" (3.361). "Defino um índice como sendo um signo determinado por seu objeto dinâmico em virtude da relação real que ele mantém com o último" (8.335).

"Um índice é um signo que remete ao objeto que denota porque é realmente afetado por esse objeto" (2.248).

"Os índices são signos cuja relação com seus objetos consiste numa correspondência de fato" (1.558). (PEIRCE in DUBOIS, 1990:62)

Os índices diferem de forma radical dos ícones e dos símbolos. Os ícones são definidos a partir de uma relação de semelhança, enquanto que o símbolos, por uma convenção geral. Peirce define então:

"Um ícone é um signo que remete ao objeto que ele denota simplesmente em virtude das características que ele possui, quer esse objeto exista realmente ou não" (2.247). (PEIRCE in DUBOIS, 1990:63)

$\mathrm{e}$

"Um símbolo é um signo que remete ao objeto que ele denota em virtude de uma lei, normalmente uma associação de idéias gerais, que determina a interpretação do símbolo por referência a esse objeto. É portanto ele próprio um tipo geral ou uma lei.“(2.249). (PEIRCE in DUBOIS, 1990:64) 
Os ícones são então signos que se ligam aos objetos denotados a partir de "virtudes" que estes possuam, não havendo necessidade de existência real desses objetos. Peirce define três tipos de ícone: a imagem, quando a característica similar é a "qualidade"; o diagrama, se a característica se dá por uma analogia de relações ou de estrutura; e a metáfora, se a característica se estabelece por um terceiro termo que serve como mediador. Fica evidente que para Peirce essa categoria dos ícones não se limita às representações figurativas como desenhos, imagens, pinturas etc. incluindo, pelo contrário todos os signos construídos a partir de uma simples semelhança de princípio com o que designam, não apenas visual, mas de qualquer ordem que seja.

Dubois referindo-se à situação indicial destaca que essa

“... definição mínima da foto, em primeiro lugar como simples impressão luminosa, não implica a priori nem que se passe por um aparelho de fotografia, nem que a imagem obtida se pareça com o objeto da qual é o traço." (DUBOIS, 1990:50)

Esta idéia de que a não é obrigatória a semelhança entre o referente e a imagem traz em si muitas implicações, pois a imagem fotográfica se ela, como um todo constitui um índice, os diversos partes da cena também são índices. Assim, abre-se espaço para a coexistência de índices ligados a diversos referentes. Isso pode não ter sido considerado importante na época por Dubois, mas tem conseqüências no campo do tratamento digital das imagens. 
Por outro lado, ele explica a ausência da necessidade da câmara dizendo que

"A mimese e a codificação perceptual da câmara escura não são seu princípio. Claro que podem intervir, mas de certa forma secundariamente. Nesse sentido, foi possível considerar, por exemplo, que aquilo que em foto se chama desde Moholy-Nagy, o "fotograma" constitui de certa maneira uma ilustração histórica dessa definição mínima: o fotograma é uma imagem fotoquímica obtida sem câmara, por simples depósito de objetos opacos ou translúcidos diretamente no papel sensível que se expõe à luz e depois se revela normalmente." (DUBOIS, 1990:50)

É importante destacar que ocorre aqui um equívoco. O processo fotográfico é na realidade um processo fotoquímico, onde a parte química opera a partir da energia eletromagnética das ondas de luz. Considerando o conceito físico de trabalho como ação que determina alguma mudança sobre a matéria, o dispositivo essencial não é químico, mas sim fotoelétrico. Esta distinção se faz necessária, pois sem ela todos os sistemas eletrônicos de imagem não podem ser considerados fotográficos, mesmo atendendo às demais características; por outro lado, as emulsões fotográficas podem responder quimicamente a estímulos de natureza não luminosa como no caso das marcas que aparecem sobre os filmes em locais em que ocorreu alguma dobra ou amassamento, denominadas apropriadamente de "exposição mecânica".

Dubois situa esse índice dentro do contexto do processo fotográfico como um todo, afirmando que 
“... o princípio do traço, por mais essencial que seja, marca apenas um momento no conjunto do processo fotográfico. De fato, na jusante e na montante desse momento da inscrição "natural" do mundo sobre a superfície sensivel, existem, de ambos os lados, gestos completamente "culturais", codificados, que dependem inteiramente de escolhas e de decisões humanas. Antes: escolha do assunto, do tipo de aparelho, da película, do tempo de exposição, do ângulo de visão etc. Tudo o que prepara e culmina na decisão derradeira do disparo. Depois: todas as escolhas repetem-se quando da revelação e da copiagem, em seguida a foto entra nos circuitos de difusão, sempre codificados e culturais: imprensa, arte, moda, pornografia, ciência, justiça, família...”(DUBOIS, 1990:50)

Ele estabelece um limite bem definido onde pode existir a situação de uma "mensagem sem código" e que se identifica com o momento em que a luz registra a imagem sobre o filme. E impõe que, apenas dentro desses limites,

“... o homem não intervém e não pode intervir sob pena de mudar o caráter fundamental da fotografia." (DUBOIS, 1990:51)

E ressalta a existência de "um momento de esquecimento dos códigos" como que uma falha, que o transforma em índice quase puro, lembrando contudo que mesmo durante esse momento 
"... apenas uma fração de segundo e (que) de imediato será tomado e retomado pelos códigos que não mais o abandonarão, (...) esse instante de "pura indicialidade", porque é construtivo, não deixará de ter conseqüências teóricas.” (id.)

Dubois insiste ainda que

“... em virtude desse mesmo princípio, a foto também é levada a funcionar como testemunho: atesta a existência (mas não o sentido) de uma realidade da conexão física entre a imagem e o referente que ela denota: é tudo o que faz dela uma impressão. A conseqüencia de tal estado de fato é que a imagem indicial remete sempre apenas a um único referente determinado: o mesmo que a causou, do qual ela resulta física $e$ quimicamente. Daí a singularidade extrema dessa relação. Ao mesmo tempo, pelo fato de ser uma foto dinamicamente vinculada a um objeto único e apenas a ele, essa foto adquire um poder de designação muito caracterizado." (DUBOIS, 1990:51)

Considerando a imagem fotográfica como índice, isso exige a presença de um objeto real em determinado lugar e momento do tempo. Apenas essa exigência, considerada fisicamente, basta para determinar uma relação única entre imagem e seu referente. Ou nas palavras de Dubois, 
"O traço (fotográfico) só pode ser em seu fundo, singular, tão singular quanto seu próprio referente. Como significação, por contato, não significa em princípio um conceito; antes de qualquer outra coisa, designa um conceito ou um ser particular no que ele tem de absolutamente individual." (DUBOIS, 1990:72)

Como conseqüência inevitável desse princípio de singularidade, deriva inevitavelmente um princípio de atestação. Dubois, prosseguindo na lógica desse raciocínio, argumenta que

"Se de fato a imagem fotográfica é a impressão física de um referente único, isso quer dizer, por outro lado, que, no momento em que nos encontramos diante de uma fotografia, esta só pode remeter à existência do objeto do qual procede. É a própria evidência: por sua gênese, a fotografia testemunha necessariamente. Atesta ontologicamente a existência do que mostra. Aí está uma característica assinalada mil vezes: a foto certifica, ratifica, autentica. Mas nem por isso, esse fato implica que ela significa." (DUBOIS, 1990:73)

Como conseqüência dessas características, evidencia-se, na fotografia uma dimensão pragmática pela qual, imagens dessa categoria não têm por si mesmas, praticamente qualquer significado. O que determina o sentido é uma relação com o objeto e com a situação em que foram feitas. 
Dubois define então que

“... a lógica do índice, (...) utiliza plenamente a distinção entre sentido e existência: a foto índice afirma aos nossos olhos a existência do que ela representa (o "isso foi" de Barthes), mas nada nos diz sobre o sentido dessa representação. O referente é colocado pela foto como uma realidade empírica (cuja) significação continua enigmática para nós, a não ser que sejamos participantes da situação de enunciação de onde a imagem provém.” (DUBOIS, 1990:51)

A ausência de significado pode levar, contudo a uma interpretação falaciosa de ausência de estrutura que Dubois evidencia citando Hubert Damish, que já em 1963 refletia que:

“A longa familiaridade com a imagem assim obtida e o aspecto bem objetivo e, por assim dizer automático, em todo o caso estritamente mecânico, do processo de registro explica que a representação fotográfica em geral pareça caminhar por conta própria e que não se preste atenção em seu caráter arbitrário, altamente elaborado (...).

Esquece-se de que as imagens, da quais os primeiros fotógrafos pretenderam apoderarse, e a própria imagem latente que souberam revelar e desenvolver, essas imagens nada têm de um dado natural: pois 
os princípios que presidem à construção de um aparelho fotográfico estão vinculados a uma noção de convencional do espaço e da objetividade que foi elaborada antes da invenção fotográfica e à qual os fotógrafos, em sua imensa maioria, só fizeram se adequar." (DAMISH in DUBOIS, 1990:39)

Na mesma linha, Bourdieu reafirma que

"Se a fotografia é considerada um registro perfeitamente realista e objetivo do mundo visivel, é porque lhe foram designados (desde a origem) usos sociais considerados "realistas" e "objetivos". E, se ela se propôs de imediato com as aparências de uma "linguagem sem código nem sintaxe", em suma de uma "linguagem natural", é antes de mais nada porque a seleção que ela opera no mundo visível é completamente conforme, em sua lógica, à representação do mundo que se impôs na Europa desde o Quattrocento." (BOURDIEU in DUBOIS, 1990:40)

Fica evidente que a força do índice ligada à sua relação especial com o objeto real, não se dá na ordem do sentido, mas apenas na ordem da existência. O índice vai até o "isso foi" de Barthes, mas jamais avança até o "isso quer dizer". Como diz Dubois: 
"A força referencial não se confunde com qualquer poder de verdade." (DUBOIS, 1990:85)

Cumpre ainda delimitar claramente a natureza e os limites do índice, como apenas um simples momento, mesmo que crucial, no processo fotográfico como um todo. Dubois aqui adverte que

"Jamais se deverá esquecer na análise, sob pena de ser enganado por essa epifania absolutizante da referência, que a jusante e a montante desse momento da inscrição "natural" do mundo na superfície sensivel (o momento da transferência automática da aparência), que, de ambos os lados, há gestos e processos totalmente "culturais" que dependem por inteiro de escolhas $e$ decisões humanas, tanto individuais quanto sociais.” (DUBOIS, 1990:85)

Completando o estudo sobre as limitações da noção de índice, é preciso evidenciar a necessidade da distância. O princípio da proximidade, da conexão física, entre signo e referente cria o risco de acabar estabelecendo uma identificação entre ambos, fazendo com que não fosse mais possível dissociá-los. A esse respeito Dubois lembra que

"convém libertar bem o signo fotográfico desse fantasma de uma fusão como real. Na fotografia, se existe necessidade (ontológica) de uma continuidade referencial, nem por isso deixa de existir (também ontologicamente) necessidade de 
um recuo, de uma separação, de um corte." (DUBOIS, 1990:87)

Essa divisão ocorre não apenas no espaço, mas igualmente na dimensão do tempo.A dualidade Aqui $\mathrm{x}$ Ali, se desdobra em Agora $\mathrm{x}$ Então. A imagem não mostra uma realidade exterior, mas principalmente anterior. Dubois afirma que

"Qualquer foto só no mostra por princípio o passado, seja este mais próximo ou distante. E essa distância temporal, que torna a fotografia uma representação sempre atrasada, adiada, em que qualquer simultaneidade entre o objeto e sua imagem não é possível.” (DUBOIS, 1990:89)

Dubois contudo, de forma precavida ressalva que

"(esta será uma das grandes diferenças das mídias eletrônicas: vídeo e circuito fechado de televisão autorizam o direto, o feed-back imediato, o autocontrole escópico naquele momento), essa distância temporal corresponde ao processo técnico da revelação, que é necessariamente inscrito na duração, com suas fases sucessivas obrigatórias, indo da imagem latente à imagem revelada e depois à imagem fixada. Mesmo no caso da Polaroid, em que o tempo de revelação foi consideravelmente acelerado, essa decalagem temporal subsiste, ainda que reduzida a poucos segundos. Como diz John Berger, "entre o 
momento recolhido na película e o momento presente do olhar que se leva à fotografia, sempre existe um abismo" (DUBOIS, 1990:89)

E mesmo estando já em 1990, considera hipoteticamente, que

"falando em termos temporais estritos, no próprio instante em que é tirada a fotografia, o objeto desaparece. (...) E mais tarde, quando a imagem revelada finalmente aparece para você, o referente já há muito não existe mais nada além de uma lembrança. O aparecimento (da imagem: sua "revelação") nunca poderá portanto satisfazer de fato sua espera. Pois como então saber se o que você está vendo no papel fotossensível é exatamente a mesma coisa que você viu? Além disso, o que você tinha visto exatamente? É sempre tarde demais. É a foto que vai se tornar sua lembrança, substituir ausência." (DUBOIS, 1990:90)

O fato é que quinze anos depois, essa situação que era considerada apenas como redução do hiato a um mínimo impossível, acaba se tornando realidade corrente, e se mostra válida. Mesmo ao usar câmaras digitais em que imagem é exibida imediatamente, permitindo o outrora confronto instantâneo entre imagem e referente, não foi nessa relação que houve de fato mudança. A explicação para esse aparente paradoxo está em que o verdadeiro distanciamento temporal não tinha sua origem 
na constrição física da demora em ver o resultado da foto, mas no tempo necessário para o trabalho psíquico de introjeção.

Procuramos até aqui organizar um conjunto de informações e conceitos para estabelecer uma camada conceitual lógico semiótica sobre a plataforma sintática de que tratamos no início. Vimos na conclusão desta parte que os princípios indiciais, mesmo oferecendo robusta base conceitual, deixam muitas questões em aberto no nível da significação. Vamos em seguida nos ocupar disso.

Serge Tisseron é o autor de um livro chamado "O mistério da Câmara Clara”, publicado em 1996 no qual se propõe a discutir as implicações psíquicas da prática da fotografia enquanto processo cultural. Ele começa seu trabalho manifestando estranheza diante da pouca atenção que a câmara fotográfica mereceu em grandes trabalhos que estabelecem referência crítica como os Walter Benjamin e Roland Barthes que contudo, chega a colocar como título de sua obra mais conhecida o nome de um instrumento ótico.

Edmond Couchot estudando a mecanização dos processos de representação considera a câmara como um aparelho que se acoplava sobre a mão e o olho do fotógrafo prolongando o corpo em direção ao mundo exterior.

Para Tisseron, contudo, a câmara é

“... muito mais do que uma simples prótese do olhar ou um brinquedo socializado. Como veremos, é o mais eficaz instrumento de familiarização e apropriação do mundo que o homem já colocou a seu serviço, já que mantém uma continuidade imediata 
com sua vida psíquica." (TISSERON, 1996:9)

O autor se propõe a demonstrar que a fotografia desde o momento de sua captação é uma forma de "pensar", e que o enfoque da obra não será a fotografia como imagem, mas sim como prática. Para ele, a fotografia transcende à câmara escura do dos artistas do Renascimento adaptada no século XIX para trabalhar com filmes, sendo antes um complexo sistema formado pelo fotógrafo e seu equipamento, interligados pelo conjunto de operações necessárias para a realização de uma fotografia. Esta afirmação parece semelhante ao conceito de sintaxe de Crawford, mas é mais abrangente, pois engloba componentes de ordem psíquica que estavam fora do escopo de Crawford.

O capítulo de introdução se intitula "100 bilhões de disparos" deixando claro que o autor não pretende se restringir apenas ao uso profissional ou estético do meio, mas sim como uma ferramenta de uso geral, onde os consumidores de imagens são, freqüentemente, seus próprios criadores. (...) Com a fotografia, pela primeira vez na história das imagens, desde a invenção do desenho, cada um se converte em fabricante de suas próprias imagens, e concorda ainda com a opinião que Edward Weston escreveu em seu diário:

"A fotografia é ou pode ser uma atividade puramente cerebral". (WESTON in TISSERON, 1996: 10)

Pode-se avaliar a complexidade dessa abordagem comparando a visão que ele mostra ao se referir aos discursos da mimese dizendo:

"A ilusão de que o mundo é semelhante à sua imagem fotografada, sustenta uma 
outra ilusão que consiste em acreditar que o mundo é semelhante à imagem que temos dele. Estas duas ilusões se encontram na idéia de que a percepção é uma espécie de "fotografia" tirada pelo olho e "revelada" em seguida no cérebro. A ilusão se sustenta através das palavras: existiria um enfoque "objetivo" que seria materializado pela "objetiva" da máquina fotográfica. Esta construção demonstra claramente o esforço da consciência para se enganar, usando para isso das ilusões que a fotografia sustenta. Entre nossas percepções e as imagens que fabricamos delas agem inúmeros filtros. Em geral, em nossa visão existem apenas as coisas que a linguagem nos permite nomear. Além disso, nossos desejos $e$ expectativas modificam constantemente a percepção do que temos ao redor. Mas é muito mais simples esquecer disso $e$ acreditar que vemos $o$ mundo como ele realmente é. A fotografia foi colocada, com toda naturalidade, a serviço dessa ilusão." (TISSERON, 1996: 18)

O impulso para fotografar, de acordo com ele, se explica a partir de uma orientação psíquica voltada para o

"desejo de conservar intactos os componentes não assimilados, para assim tornar possível sua assimilação posterior. Este é o principal motivo porque o desejo de 
fotografar um lugar ou uma situação é mais intenso quando se tem a sensação de que o encontro com o local ou a situação foi demasiadamente rápido. Assim, as sensações e emoções vividas não puderam ser processadas de forma suficiente para serem reconhecidas e nomeadas.” (TISSERON, 1996: 18)

Ele aborda a mesma questão das fotos feitas por turistas, das quais Baudelaire dizia:

"Que ela(s) enriqueça(m) rapidamente o álbum do viajante e que devolva aos seus olhos a precisão que falta à sua memória. (...) Mas se lhe(s) for permitido invadir o domínio do impalpável e do imaginário, tudo o que só é válido porque o homem lhe acrescenta a alma, que desgraça para nós." (BAUDELAIRE in DUBOIS, 1990:29),

Mas avalia que esse desejo de preservar componentes não assimilados seja a

“... motivação principal dos turistas que se apressam em fotografar monumentos que se supõe que tenham visto, antes que o ônibus da excursão prossiga. Acreditam que mais tarde, graças a suas fotografias, poderão recuperar as percepções sentidas fugazmente e dedicar o tempo necessário para assimilá-las.” (TISSERON, 1996: 26) 
Nesse sentido, ele vê a fotografia como

\begin{abstract}
"uma forma de participação empática no mundo. O fotógrafo, mais do que registrar o mundo, o acompanha. A fotografia é menos um modo de "parar" o mundo - segundo a fórmula clássica de "morte simbólica" - do que um modo de tentar tocar a ferida do tempo vivo. Isto ocorre porque a fotografia implica em duas séries de operações simultaneamente contraditórias e complementares, de corte-captura por um lado e de abertura - conexão por outro." (TISSERON, 1996: 49)
\end{abstract}

Ele associa essas operações contraditórias a

“... dois conjuntos de ressonâncias imaginárias - correspondentes ao corte e à conexão - (que) se unem ao redor da luz para fazer da fotografia o lugar privilegiado de uma transfiguração. A luz está em primeiro plano em toda fotografia. Muitas vezes, o que desperta o desejo de fotografar é o impacto emocional provocado por uma determinada qualidade de luz. Para muitos fotógrafos, a luz é o objetivo principal da fotografia." (TISSERON, 1996: 54) 
E reconhece que isso se opõe

"ao que Roland Barthes tratou de estabelecer como característica absoluta da fotografia. A fotografia não evoca a destruição do mundo e sua precária sobrevivência através da imagem, mas pelo contrário, a sua transformação incessante." (TISSERON, 1996: 72)

Para Tisseron, fotografar, portanto é

"assegurar-se de que o caminho que leva da percepção à representação permanece aberto; é materializar esse caminho (ou processo). (...) Na verdade, fotografar é percorrer constantemente o caminho que vai desde a percepção (estado psíquico saturado pelos sentidos no qual se encontra o fotógrafo no momento que faz a foto) até a representação (a imagem fotográfica que subsiste como única testemunha daquele momento). (TISSERON, 1996: 74)

E continua a análise do processo de corte e reconexão explicando que

"Separar-se sem morrer é o dilema inconsciente que deixa sua marca sobre todo propósito de distanciamento. A fotografia não apenas não "mata" o objeto $d a$ representação como principalmente nos garante que, qualquer que seja a distância 
que nos separe dos objetos escolhidos, o caminho desde a percepção até a representação se mantém sempre aberto. (...) Portanto, pode ser utilizado a qualquer momento durante o trabalho de introjeção. A fotografia nos garante assim, a continuidade de nossa vida psíquica." (TISSERON, 1996: 77)

Tisseron começa então a discutir a questão da reconexão, mostrando que, do ponto de vista psicanalítico, o discurso da semelhança não consegue se sustentar pois

"Toda a fotografia, na qual acreditamos captar uma imagem à nossa semelhança, mostra, na verdade, a imagem de um estranho. Toda a "semelhança" na fotografia não é assim mais do que uma correspondência entre a imagem interior que o observador tem de uma coisa e a imagem dessa mesma coisa que a fotografia lhe oferece." (TISSERON, 1996: 81)

E prossegue, baseando sua análise no pensamento de Lacan, dizendo que

"No âmbito da "imagem de si mesmo", essa busca de uma adequação à imagem que fazemos de nós mesmos supõe uma verdadeira alienação: podemos perfeitamente nos reconhecer em uma imagem que não nos é parecida, ou pelo contrário, negarmos nos reconhecer em uma 
imagem que nos é parecida. Na verdade, esta alienação na imagem fotográfica de si mesmo tem, para cada pessoa, uma origem histórica: o descobrimento da primeira imagem de si mesmo em um espelho. (...) Visto que a fotografia não pode nos mostrar tal como acreditamos ser, só nos resta a possibilidade de usar seus recursos para tentarmos nos ver como gostaríamos de ser." (TISSERON, 1996: 82)

A questão da memória visual se liga, de forma complexa, a outras experiências sensoriais não visuais que podem assim

"voltar à mente de forma totalmente separada das participações emocionais $e$ afetivas que ocorreram na situação inicial. Da mesma forma, toda fotografia nos impõe a representação gráfica de um lugar ou de um acontecimento, de forma totalmente independente das participações afetivas $e$ motoras (importante: a coreografia na hora da captação) que se produziram realimente em sua percepção. Por isso toda fotografia de um lugar familiar pode nos parecer estranha. Não reconhecemos esse lugar tal como o percebemos de costume, porque não encontramos as múltiplas experiências que ocorreram, na realidade, em nossa percepção. Quanto mais intensas são as experiências não visuais vinculadas a um objeto, pessoa ou paisagem, maior a 
probabilidade de que não os reconheçamos em sua simples imagem. Porque jamais encontraremos nela as experiências sensoriais privilegiadas que constituem o fundamento de nossa relação com eles." (TISSERON, 1996: 91)

Mesmo assim, continuando na abordagem da questão das percepções não visuais, Tisseron mostra que

"A fotografia não permite apenas nos encontrarmos com a lembrança visual de um acontecimento, mas também com o que são seus diversos componentes sensoriais. (...) Todas essas sensações constituem o conteúdo sensorial indispensável para a reconstrução da imagem, emocionalmente viva, de um acontecimento. Formam como que um escaninho onde a imagem visual da recordação encontra seu nicho adequado. Se a fotografia pode suscitar desta maneira certas lembranças não visuais de um acontecimento, isto ocorre, é claro, por sua proximidade com a lembrança visual. (TISSERON, 1996: 124)

Levando em seguida a questão da conexão para além do imaginário individual, considerando que os processos envolvidos quando as imagens são mostradas ou publicadas, o autor diz que:

"ver uma fotografia é se defrontar, muito mais do que com a pintura, com o 
imaginário da imagem compartilhada. Diferente da pintura que se mostra como uma representação subjetiva de seu criador, a fotografia se exibe, de fato, com a ilusão de uma representação objetiva do mundo. Por isso alimenta muito mais do que a pintura, a ilusão de uma identidade de percepção entre seus diversos espectadores. Às vezes, essa experiência nos parece adquirida: ver uma imagem, ao mesmo tempo que outra pessoa, é sempre imaginar que essa pessoa a enxerga como nós mesmos a vemos. E quando essa situação não é percebida como algo que acontece de forma espontânea, mesmo assim desejamos que isso se produza. Desejamos especialmente compartilhar as imagens que nos perturbam, mesmo que, por definição, sejam impossíveis de se comunicar, como nossos sonhos. Nós os contamos com a ilusão de comunicar suas imagens a quem está a nosso redor, mesmo que elaborem, é evidente, uma visão totalmente diferente da que nós acreditamos estar lhes comunicando.” (TISSERON, 1996: 113)

O processo de memória é por natureza fragmentado e lembrando que

"Quase sempre recordamos imagens isoladas de um acontecimento e só muito raramente seu desenvolvimento contínuo 
como em uma cena cinematográfica." (TISSERON, 1996: 124)

Tisseron aponta que a fotografia funciona então como

“... ponto de referência para as qualidades sensoriais relacionadas com o objeto fotografado, mas não percebidas no momento da captação. Pode, particularmente, reunir diversas formas de lembranças relacionadas com o mesmo objeto, ocorridas, porém, em momentos diferentes. Esta capacidade a converte em um poderoso auxiliar do trabalho de introjeção psíquica ao permitir a união de fragmentos dispersos de experiências emotivas e sensoriais que até então não encontravam suporte satisfatório em uma imagem visual interior (id.)

Para finalizar, Tisseron mostra em sua análise relação semelhante à estabelecida por Dubois ao abordar, usando conceitos de Peirce, a questão do índice fotográfico, dizendo que

"na fotografia, a certeza de que o referente sem dúvida existiu, impõe como conseqüência a certeza de ter existido tal como eu o percebo subjetivamente na imagem. O "isto foi" de que fala Barthes constitui claramente uma verdade da fotografia, considerada em sua forma geral. Mas, constitui também, com certeza, um 
engano na relação que cada pessoa estabelece, em particular, com cada fotografia. Este engano consiste em acreditar que o "isto foi", de que a fotografia dá testemunho, se confunde com o "isto foi assim" que eu me sinto tentado a ver nela." (TISSERON, 1996: 131)

Tisseron encerra a obra afirmando que

A "câmara escura" é a prótese tecnológica que o ser humano soube adaptar de forma mais eficaz a suas necessidades psíquicas de assimilação do mundo. (TISSERON, 1996: 156)

Concluímos aqui a montagem de uma estrutura teórica composta por abordagens interdependentes de natureza sintática, semiótica e psíquica que serão usadas como base para a análise da prática que será empreendida a seguir. 
CAPITULO 5

\section{Prática}


A prática do processo fotográfico

Edmon Couchot, em "A tecnologia na arte: da fotografia à realidade virtual", se refere a Leon Battista Alberti, autor da obra "De Pictura" (1435), citando o "intersector" dispositivo constituído por um véu de fios muito finos montados sobre um quadro de madeira. Não é difícil perceber nisso a origem do vidro despolido, posteriormente utilizado nas câmaras fotográficas.

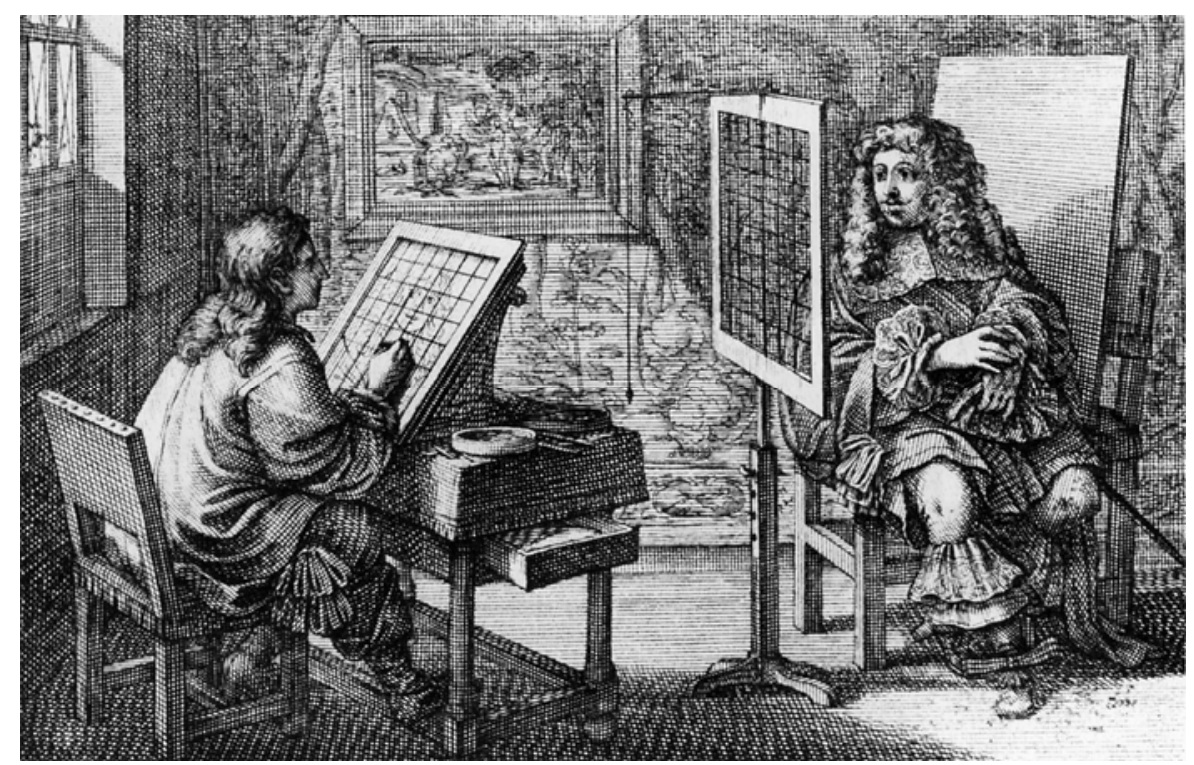

Couchot descreve então o processo estabelecido por Alberti, para quem:

“...o quadro é o resultado de uma série de operações bem hierarquizadas. A mais elementar consiste em delimitar as pequenas superfícies componentes dos objetos. Graças ao intersector, o pintor capta - "mede" - com precisão os contornos dos objetos, ele os desenha, ou como diz Alberti, ele os circunscreve. Neste trabalho de circunscrição, pelo qual começa a 
pintura, a mão e o olho constituem com o intersector uma máquina simples, mas poderosa, que automatiza uma parte importante do processo pictórico. Entretanto, as superfícies devem ser reunidas entre si para formar os membros, os quais formarão, por sua vez, os corpos. Alberti chama este trabalho de composição. Quanto ao encaixe final dos corpos, este é regulado pelo que ele nomeia a história, “ último degrau de acabamento da obra do pintor". (COUCHOT, 2003:29)

Importa aqui destacar a idéia de que a produção de imagens é fruto de uma seqüência hierarquizada de operações, e que essa hierarquia determina relações de inter dependência entre as diversas etapas do processo.

Couchot prossegue em sua análise dizendo que

A história é para Alberti bem mais do que a mensagem do quadro. É graças a ela que o agenciamento dos corpos figurados retém $e$ emociona os olhos e a alma dos espectadores. "A história, diz ele ainda, é a função mais importante do pintor." $O$ método perspectivista exige então um duplo trabalho do pintor. Por um lado o trabalho mecânico (...) durante o qual o instaurador da imagem faz corpo com um aparelho ótico e geométrico. (...) A segunda operação exige do mesmo sujeito que ele se diferencie dos 
outros pintores na maneira de ser e de ver $e$ que afirme sua singularidade. Ela reclama uma atitude rebelde à automação. (id)

Para Couchot,

"A fotografia marcou uma etapa suplementar e decisiva na automação da representação. Com ela, o conjunto do trabalho executado pela dupla olho-mão na perspectiva através do intersector é totalmente desempenhado pelo aparelho fotográfico. "É o modelo que faz seu próprio retrato", dizia Ken ou "É a luz que pinta, que desenha" dizia Disdéri." (COUCHOT, 2003:32)

Continuando, afirma que:

"A placa fotográfica funciona oticamente como o véu de Alberti, um véu que inscreveria automaticamente na sua superfície a imagem das coisas vistas da realidade visível e enquadrada.

O tempo reservado à composição, (...), se reduz desde então ao tempo mecanizado da pose, encurtado ao instantâneo (as poses muito longas deixam escapar os objetos em movimento)." (id)

Essa é uma visão simplista na qual, como advertiu Crawford, o equipamento é visto como elemento central. Mas, já se afastou de 
abordagens em que se considera apenas a imagem pronta e não a totalidade de seu processo de produção. Com efeito, tanto para Dubois como para Tisseron, a fotografia tem que ser vista como um processo com muitas etapas em que decisóes tomadas ao longo de cada uma delas têm influencia sobre o resultado final.

Na visão de Couchot não existe, por exemplo, a questão da focalização, que é uma etapa específica do processo de registro das imagens. As questões de tempo e movimento são consideradas apenas sob seu aspecto técnico, como um problema a ser resolvido e não como um recurso de linguagem. Couchot, enfim se mostra tão ocupado com a teoria do processo que parece esquecer que as imagens são feitas ao longo de seqüências de operações práticas, que são dependentes das características dos equipamentos e da forma como o fotógrafo se relaciona com eles.

É evidente que a hierarquia de operações utilizada por um pintor ao fazer um quadro usando o intersector ou a câmara escura seria totalmente diferente daquela usada por um fotógrafo ao trabalhar com uma câmara de formato grande, usando chapas de filmes. Mas o fato é que existiria uma hierarquia relativamente rígida, ditada pelas características do equipamento. Qualquer pessoa que tenha operado equipamentos desse tipo sabe que existe uma separação muito clara e definida entre as operações de enquadramento, composição e focalização e a etapa posterior de registro da foto, após a qual leva algum tempo para que o equipamento esteja pronto para iniciar outro ciclo.

Isso leva a um modo de operação em que grande parte das decisões se toma algum tempo antes do momento do registro. No momento de acionar o disparador praticamente tudo já está decidido.

Mesmo sem contar com um Alberti para codificar o procedimento a ser adotado, a experiência cotidiano acaba mostrando qual a seqüência que 
funciona melhor ou ao menos aquela que seja mais lógica em termos de economia de tempo e/ou de materiais.

O tamanho da câmar e o uso de filmes em chapas são então determinantes de um modo de operação, ou como diria Crwqford, estabelecem um limite sintático no registro de imagens nessas condições.

Maurício Lissovsky, no ensaio "o tempo e a originalidade da fotografia moderna" cita trabalhos como as imagens de corridas de automóveis feitas por Jacques Henri Lartigue em 1912 para as assim chamadas "anamorfoses" como fotos feitas para registrar o movimento, numa época em que os recursos técnicos já teriam permitido um adequado "congelamento". Independente da questão do tempo, a imagem abaixo mostra claramente como as características técnicas dos equipamentos determinam alterações profundas na formação e registro das imagens.

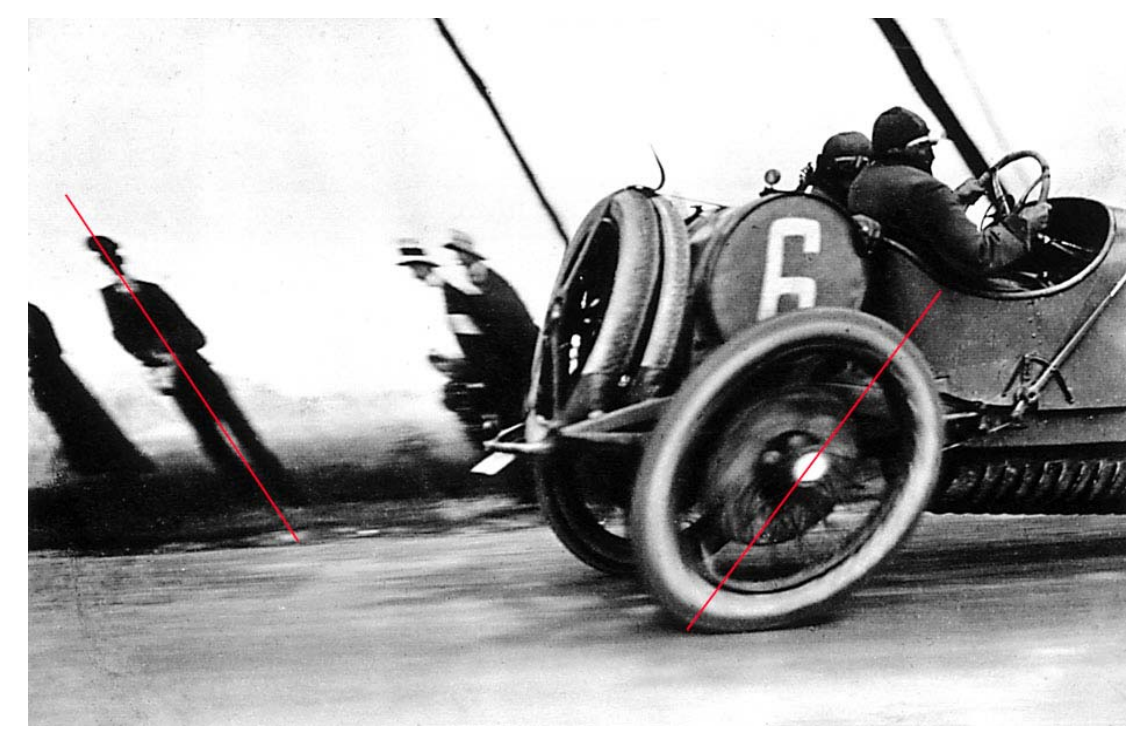

Com efeito, as distorções indicadas pelas linhas vermelhas são decorrentes das características do equipamento. Na câmara usada por Lartigue a exposição se fazia por meio de um obturador de plano focal 
em que duas cortinas corriam sucessivamente, logo à frente da película, ao longo da dimensão vertical do fotograma. O tempo de exposição é determinado pelo intervalo entre a ação da primeira e da segunda cortina.

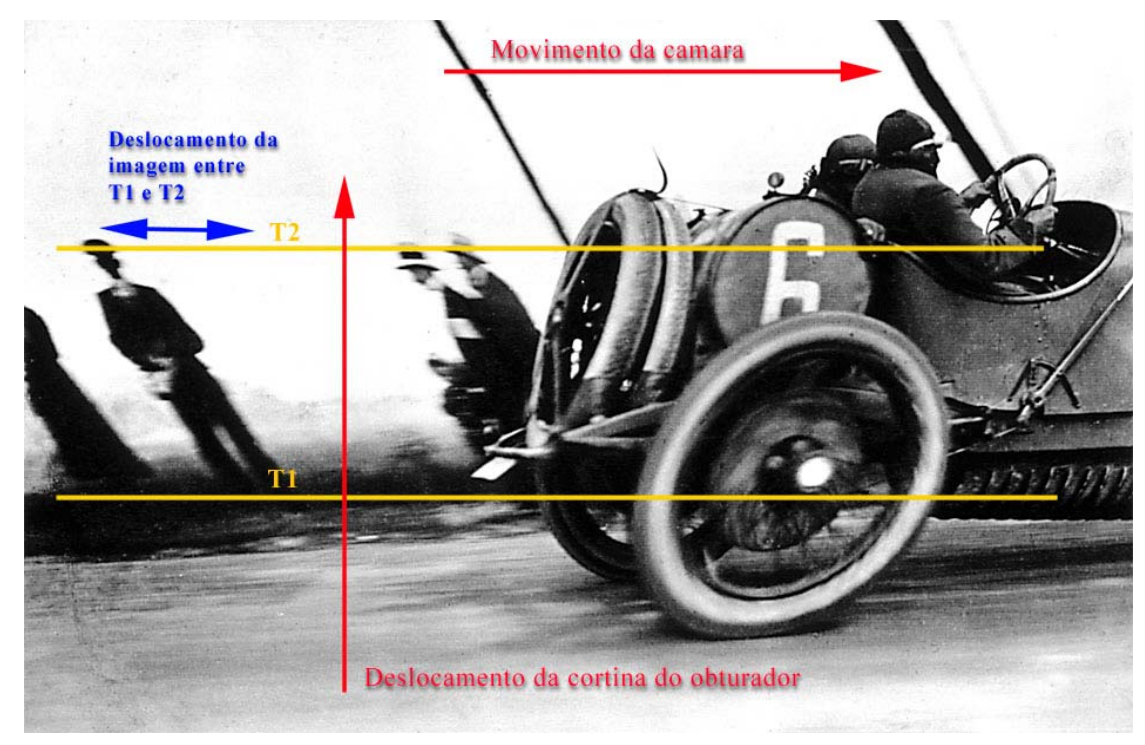

Tempos de exposição curtos fazem com que essa diferença entre o corrimento das duas cortinas seja bastante pequena. Na prática a exposição se dá através de uma fenda estreita que atravessa o fotograma. Ou seja, não há um momento em que a área total do fotograma esteja sendo exposta simultaneamente. Mesmo sendo o tempo de exposição curto, caracterizando o "instantâneo", o instante da parte superior da imagem é diferente do instante da parte inferior.

Neste caso particular, a câmara estava dentro de um carro em movimento. Os elementos de imagem estáticos se mostram deslocados para a esquerda enquanto que, um outro veículo, em velocidade maior do que aquele em que estava a câmara, mostra inclinação em sentido oposto. 


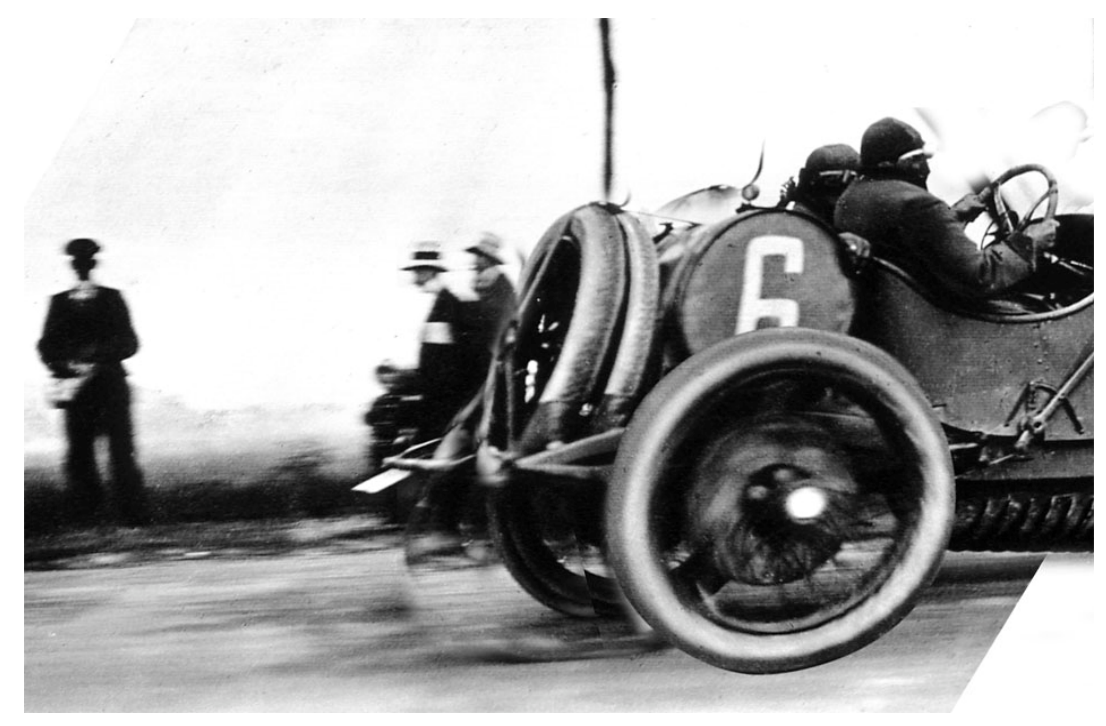

A imagem acima passou por um pequeno trabalho de edição, procurando compensar as distorções citadas e parece evidente que muito da força da imagem original, que se perdeu na imagem corrigida, se devia justamente a elas.

A solução de engenharia adotada no projeto do obturador dessa câmara teve influência na aparência da imagem produzida. Não quer dizer que todas as imagens feitas com esa câmara saiam com essa distorção que só isso só aparece ao registrar cenas com objetos em movimento rápido. $\mathrm{Na}$ maior parte dos casos o obturador cumpre sua função sem deixar vestígios. Do ponto de vista da imagem, se poderia hoje dizer que na grande maioria das cenas seu funcionamento é "transparente" e ironicamente o termo se mostra apropriado pelo fato de que ele permite que a luz passe através dele. Sempre de forma controlada, é claro.

A influência neste caso é de ordem mecânica, mas outras influências físicas podem surgir em decorrência das soluções empregadas no projeto dos equipamentos. A famosa câmara Rolleiflex com duas objetivas é um desses casos. 


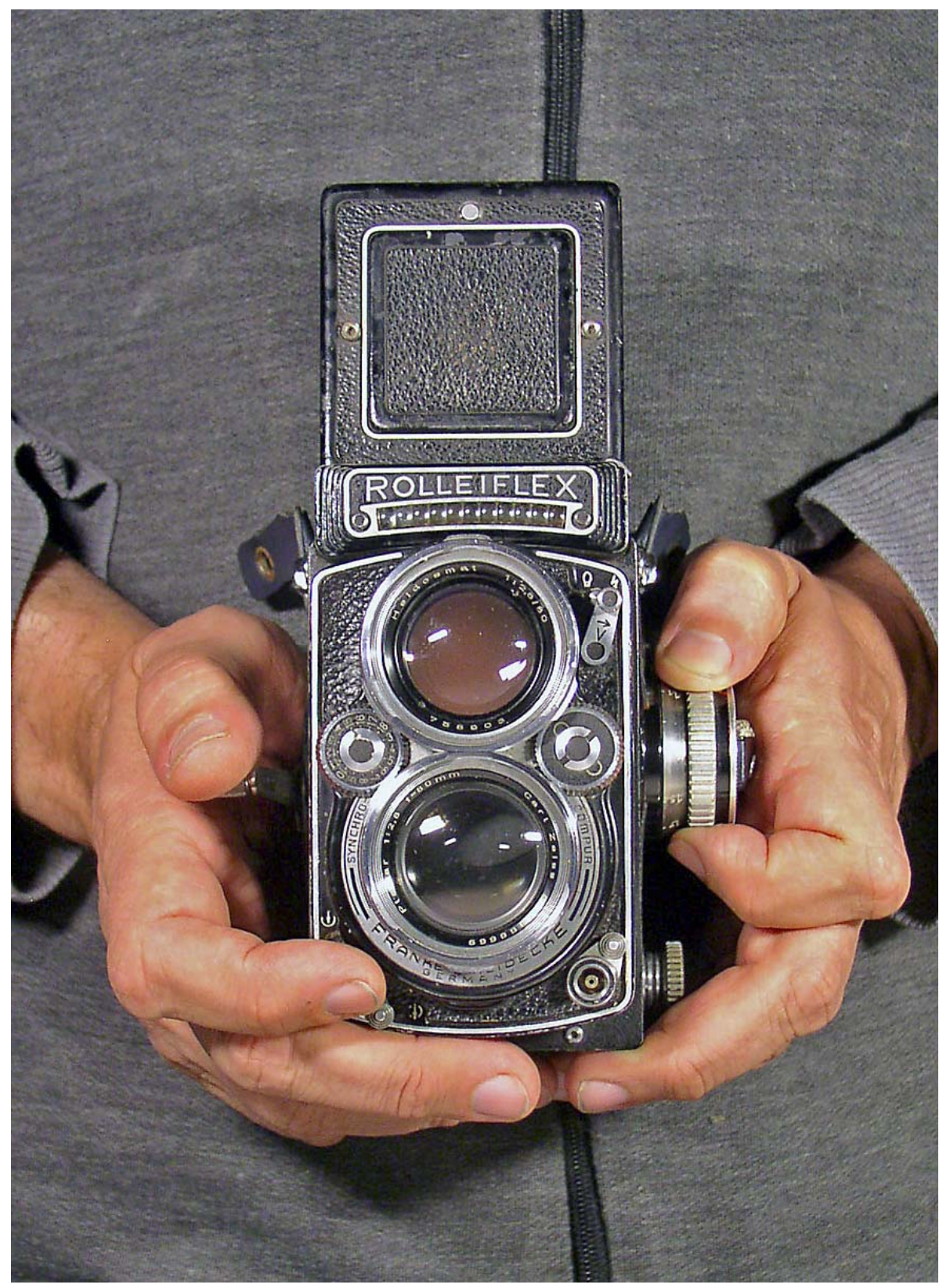

Essa câmara tem dois visores e pode ser usada tanto no nível do olho como na altura da cintura, olhando por cima para fazer $o$ enquadramento. $\mathrm{O}$ projeto ergonômico foi pensado levando em conta $\mathrm{o}$ uso predominante na posição mostrada acima, usando o visor principal que forma a imagem usando a objetiva superior. Nessa situação, a imagem exibida no visor aparece invertida lateralmente, como se pode ver abaixo. 


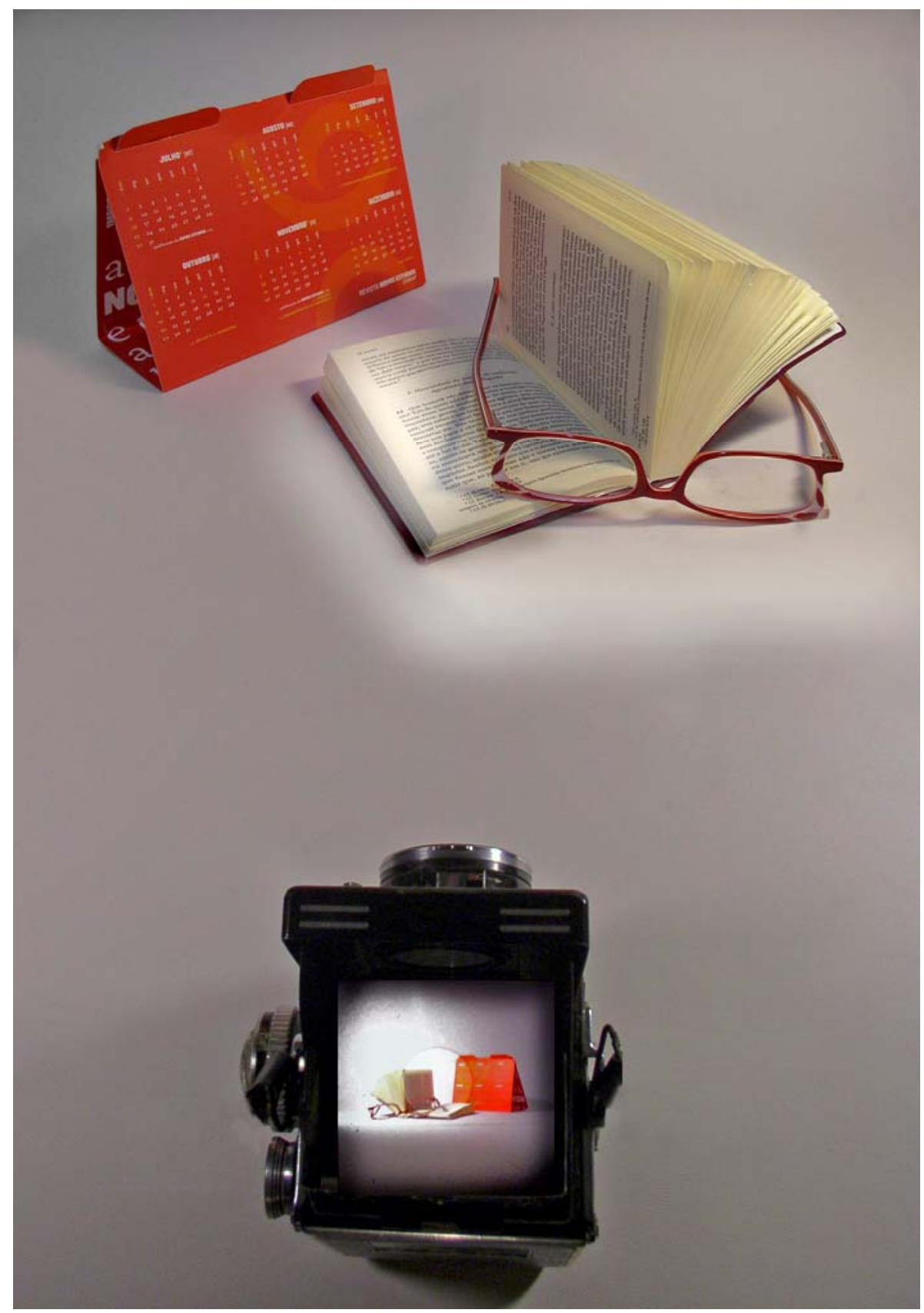

A imagem do visor não é usada apenas para fazer o enquadramento, vendo o que vai sair na foto, mas também e principalmente para estabelecer a composição, avaliando "como" vai sair a foto. Essa inversão da imagem pode ter influência nessa avaliação. 


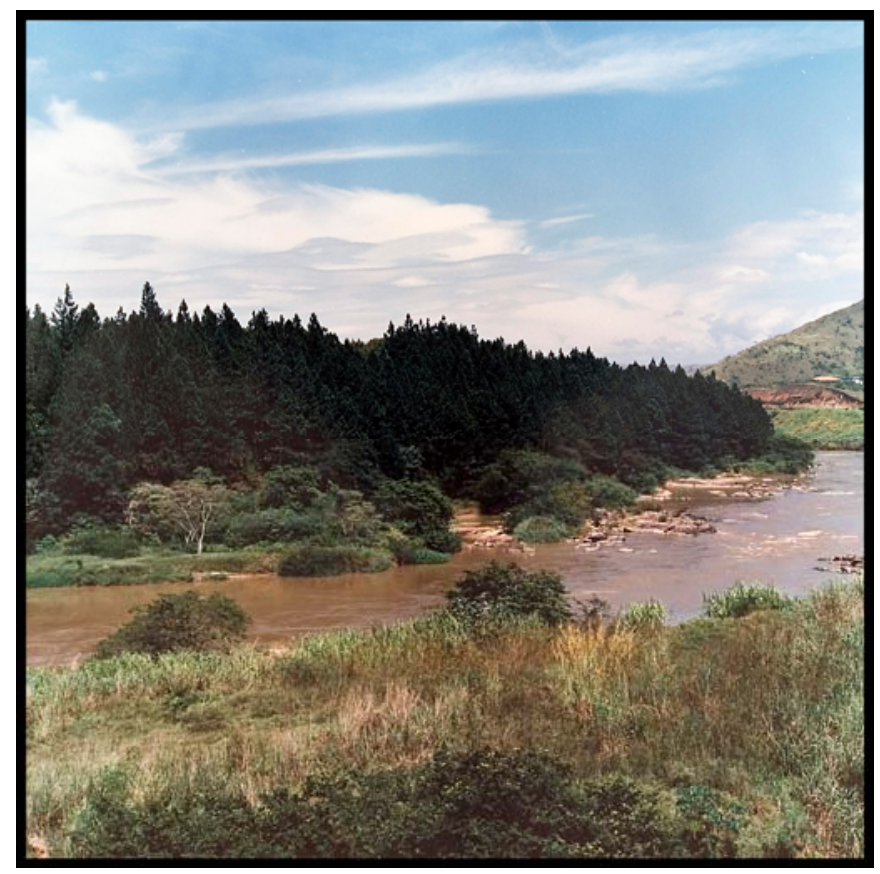

Foi o que correu, por exemplo, num ensaio realizado por um fotógrafo no vale do Paraíba no início da década de 1990. Ele usava há vários anos câmaras $35 \mathrm{~mm}$ de tipo reflex, com prisma. Para fazer o ensaio, contudo, pensando obter imagens de melhor qualidade optou por um formato maior. Depois de revelados os filmes mostraram resultados tecnicamente perfeitos, mas em muitos casos, visualmente decepcionantes, ou pelo menos bastante estranhos, diferentes da expectativa do autor. Estudando atentamente o material surgiu a hipótese da inversão no visor que foi confirmada ao fazer algumas ampliações com o negativo invertido lateralmente, como mostram as imagens acima e abaixo. Elas precisam ficar separadas devido à inevitável interferência mútua caso fossem vista lado a lado. 


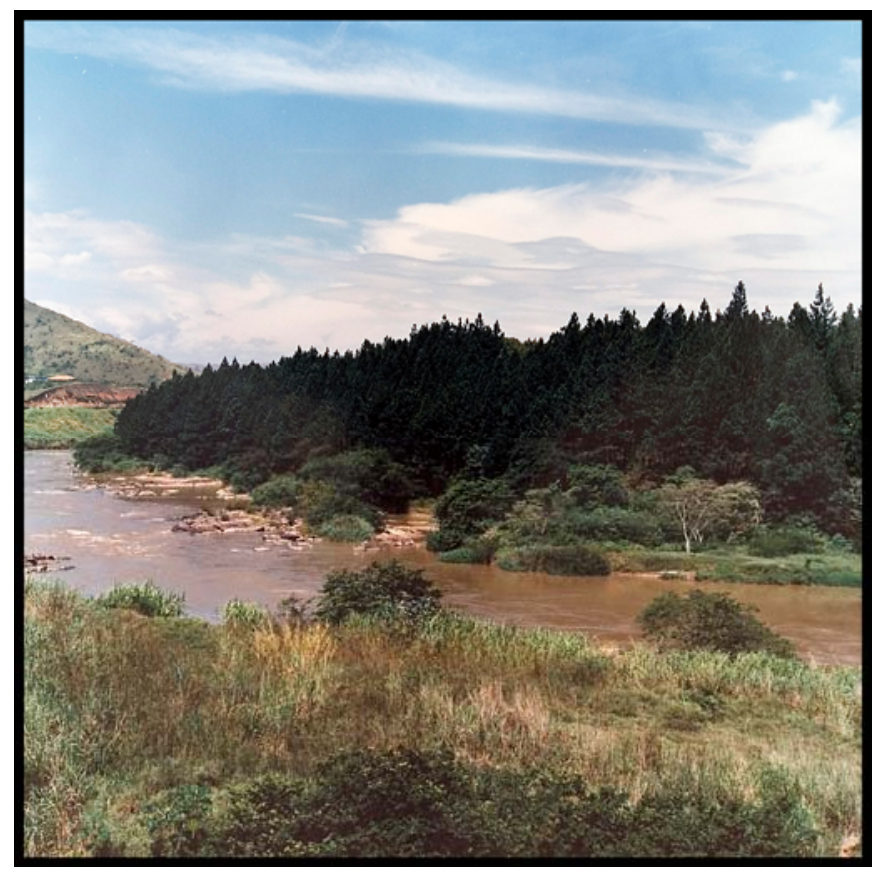

È interessante observar que a técnica de ampliar negativos invertidos lateralmente sempre foi velha conhecida de fotógrafos retratistas como solução para atender clientes insatisfeitos com os resultados, pois as novas cópias mostravam a pessao cliente da forma como ela estava acostumada a se ver no espelho. Tisseron ou Lacan provavelmnete não teriam imaginado solução tão simples.

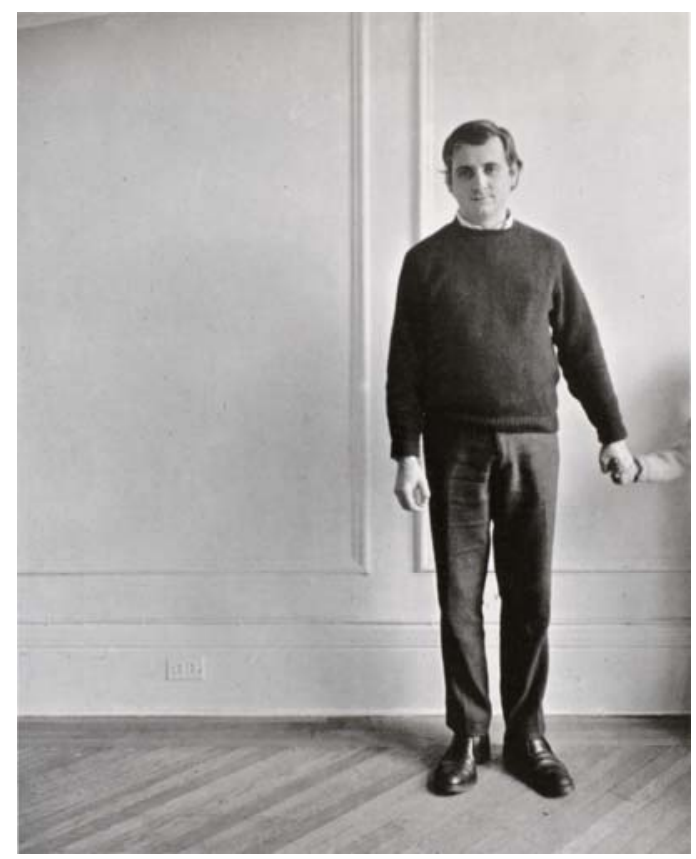


O fotógrafo Otto Stupakoff publicou em um livro de fotografias a imagem acima (Auto retrato com Ian, New York, 1966). É possível que este tenha sido mais um caso em que a inversão lateral da imagem no visor da câmara surpreendeu o autor. Seja como for, a publicação da imagem demonstra que a interação com o equipamento foi incorporada como elemento de linguagem.

Parece demasiado óbvio afirmar que as características do equipamento têm influência nas imagens, mas a obviedade se refere em geral ao tamanho da imagem ou à qualidade das lentes. Influências mais sutis podem passar despercebidas.

A indústria fotográfica vem ao longo das décadas se empenhando em desenvolver soluções técnicas para facilitar o uso dos equipamentos pelos fotógrafos. Essas modificações além da facilidade foram trazendo consigo alterações no modo de operação dos sistemas que por sua vez determinaram mudanças inclusive na linguagem fotográfica.

Nas primeiras câmaras que usavam filmes em rolo, o transporte do filme se fazia por meio de um botão ou uma alça dobrável conhecida como "borboleta". A operação de carregamento do obturador era independente do transporte do filme. Era bastante comum esquecer de avançar o filme e assim perder não uma, mas duas fotos que saiam sobrepostas. A solução para resolver o problema foi acoplar os dois sistemas fazendo com que o carregamento do obturador fosse feito junto com o transporte do filme. Mais tarde surgiu a idéia da alavanca de transporte, substituindo o botão giratório no transporte do filme. Isso permitiu que o fotógrafo operasse o equipamento sem tirar o olho do visor como era necessário com o botão giratório. Influências desse tipo quase nunca foram consideradas nos trabalhos críticos que se concentram, em geral, 
nas imagens como produto acabado, não levando em conta o processo como um todo.

Dissemos no início deste trabalho que a prática profissional mostrava uma relação inversa entre o formato dos filmes e a quantidade de imagens produzidas. Indo além das óbvias razões econômicas, podemos encontrar explicações para isso dentro do próprio modelo sintático formulado na dissertação de mestrado que apresentei em 1988, "Sintaxe Fotográfica: proposta para um curso".

No ensaio anteriormente citado, Lissowsky procura mostrar como ocorre esse processo de transformação, pelo qual o tempo se condensa em instante, analisando as obras de alguns fotógrafos, entre eles August Sander e Henri Cartier-Bresson sendo este último uma escolha quase inevitável quando se considera que, além da vasta obra que se estendeu durante grande parte do século XX, estabeleceu um conceito importante que também se relaciona com o tempo e o instante que é a idéia do “MOMENTO DECISIVO”.

"Fotografar é reconhecer,num mesmo instante e numa fração de segundo, um fato $e$ a organização rigorosa das formas percebidas visualmente que exprimem esse fato" (CARTIER-BRESSON, in LISSOWSKY: 2003:142s)

Para Lissowsky, nas obra de Sander e Cartier-Bresson a espera assume formas passivas, se bem que diferenciadas e quanto a Cartier Bresson, afirma que: 
ele também acredita na espontaneidade do instante, mas comparou-se a si mesmo não a um fazendeiro que vê o capim crescer espontaneamente, mas ao arqueiro-zen. A atitude é passiva, uma vez que sua deambulação em busca da imagem não é um rastreamento do espaço, mas o favorecimento de um curto-circuito entre o fotógrafo e sua meta. Este curto-circuito (a configuração fotografável) surge ao acaso, em meio a uma evolução fortuita da forma do mundo. Não é por outro motivo que Cartier-Bresson achava "intolerável" tentar obter a mesma foto "uma segunda vez". (LISSOVSKY, 2003:142)

A parte final da citação acima apresenta uma ambigüidade sutil que é importante analisar. A palavra "foto" pode, por um lado, ser entendida como a imagem única, obtida ao disparar o obturador da câmara. Neste caso, cada fotograma é uma foto e as imagens que foram produzidas antes depois não são instâncias diversas da mesma foto, mas sim outras fotos, independentes.

Mas é também possível entender a palavra "foto" como se referindo ao conjunto de imagens produzidas em uma determinada situação. Neste caso, a espera adquire uma atitude muito menos passiva na qual podemos pensar o processo de produção de forma interativa, sendo cada imagem resultante de uma etapa de síntese temporal-espacial seguida de uma etapa de análise que irá influir na síntese da imagem seguinte.

Para compreender esta abordagem precisamos considerar as características dos equipamentos utilizados na produção das imagens. A 
produção fotográfica de Cartier-Bresson se dá utilizando o formato 35 mm e particularmente as câmaras Leica, inicialmente nos modelos II e III e depois, a partir de 1954, os modelos da linha M.

O filme $35 \mathrm{~mm}$ oferece autonomia para 36 imagens sucessivas, antes de ser preciso recarregar a câmara. Consta que Cartier-Bresson produzia algo como 5 rolos de filme por dia, cerca de 180 imagens. Não consegui ainda confirmar esta informação, mas parece razoável supor que sua tendência tenha sido semelhante à da maioria dos fotógrafos que usam formatos pequenos, que optam por produzir material de forma abundante durante a etapa de captação, com subseqüente depuração na fase de pósprodução. Mesmo com a apologia do instante, parece evidente que existe uma etapa de pós-produção e mesmo que ela se restrinja a selecionar a "melhor" imagem dentro de um conjunto, considerando a fotografia como um processo, fica difícil aceitar que $o$ ato fotográfico esteja completo no momento de acionamento do disparador.

Parece claro então que existem dois momentos de decisão, um na fase de captação e outra na de pós-produção. Ambas definem o que será o produto final fotográfico. Até os amadores se acostumaram, a fazer mais de uma foto da cena, ao menos para se garantir de algum acidente no laboratório ou dispor de uma alternativa para uma eventual foto tremida. Com os profissionais a produção de muitas fotos de uma mesma cena assume o caráter de um processo de busca da melhor imagem. Inclui, é claro, a idéia de garantia que leva o amador a "fazer mais uma foto", mas vai muito além. Com efeito, a seqüência continuada de operações de enquadrar, fotografar, enquadrar, fotografar, cria um processo de realimentação em que, a cada disparo do obturador a situação é reavaliada em busca de algum aperfeiçoamento com relação ao que se fez até aquele momento. 
Após a revelação, é preciso fazer a análise dessas fotos para avaliar os resultados e escolher a foto que apresenta melhor resultado. Para facilitar esse trabalho normalmente se faz uma cópia de prova. Isso tradicionalmente se fazia colocando os negativos sobre uma folha de papel fotográfico, com uma placa de vidro em cima para manter os filmes prensados sobre a folha, que era conhecida como "prova de contato" ou apenas "contato". Essas provas evitavam o perigo de danificar os negativos ao manipulá-los durante as operações de análise e seleção. Se bem que, ironicamente, muitos riscos e danos surgiam por vezes exatamente durante a produção de produção das provas.

Muitas discussões entre fotógrafos e laboratórios surgiam a partir de situações nas quais negativos danificados se contrapunham a folhas de contatos que mostravam as imagens sem riscos, evidenciando que os mesmos haviam surgido dentro laboratório, se bem que depois da produção das folhas de contato, fazendo com que essas provas passassem a sem também incriminatórias mostrando o desleixo do laboratório.

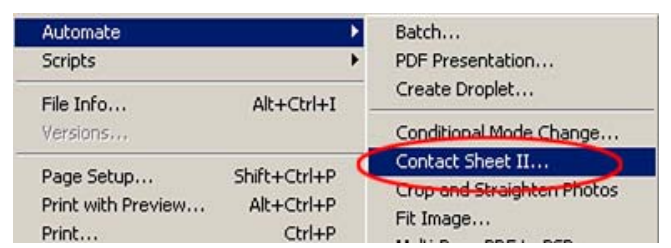

A imagem acima, de um dos menus do editor Photoshop, mostra que a denominação continua sendo usada, mesmo para provas feitas a partir de imagens digitais que não têm, evidentemente, qualquer contato físico com a folha impressa.

Os fotógrafos, na maior parte dos casos, olham as folhas com a atenção voltada para cada imagem individualmente, procurando aquela que mostre o melhor resultado. É claro que isso exige uma avaliação 
comparativa entre as diversas imagens, mas a preocupação com o conjunto das imagens não é em geral dominante.

Essas folhas foram quase sempre consideradas apenas cópias de serviço, sem maior importância. Nos laboratórios de jornais, onde a pressa impera, muitas vezes nem eram lavadas adequadamente, já que seriam descartadas dentro de poucas horas.

Assim, não é de estranhar que grande parte das análises críticas tenha dado pouca ou nenhuma importância para esse tipo de material, já que esses trabalhos estão voltados apenas para a imagem, não se preocupando com seu processo de produção. E, por outro lado, é significativo que $o$ interesse surja justamente nas análises que consideram a imagem fotográfica pronta como parte de um "ato fotográfico" mais complexo, no qual essa imagem por vezes, não é sequer a última etapa.

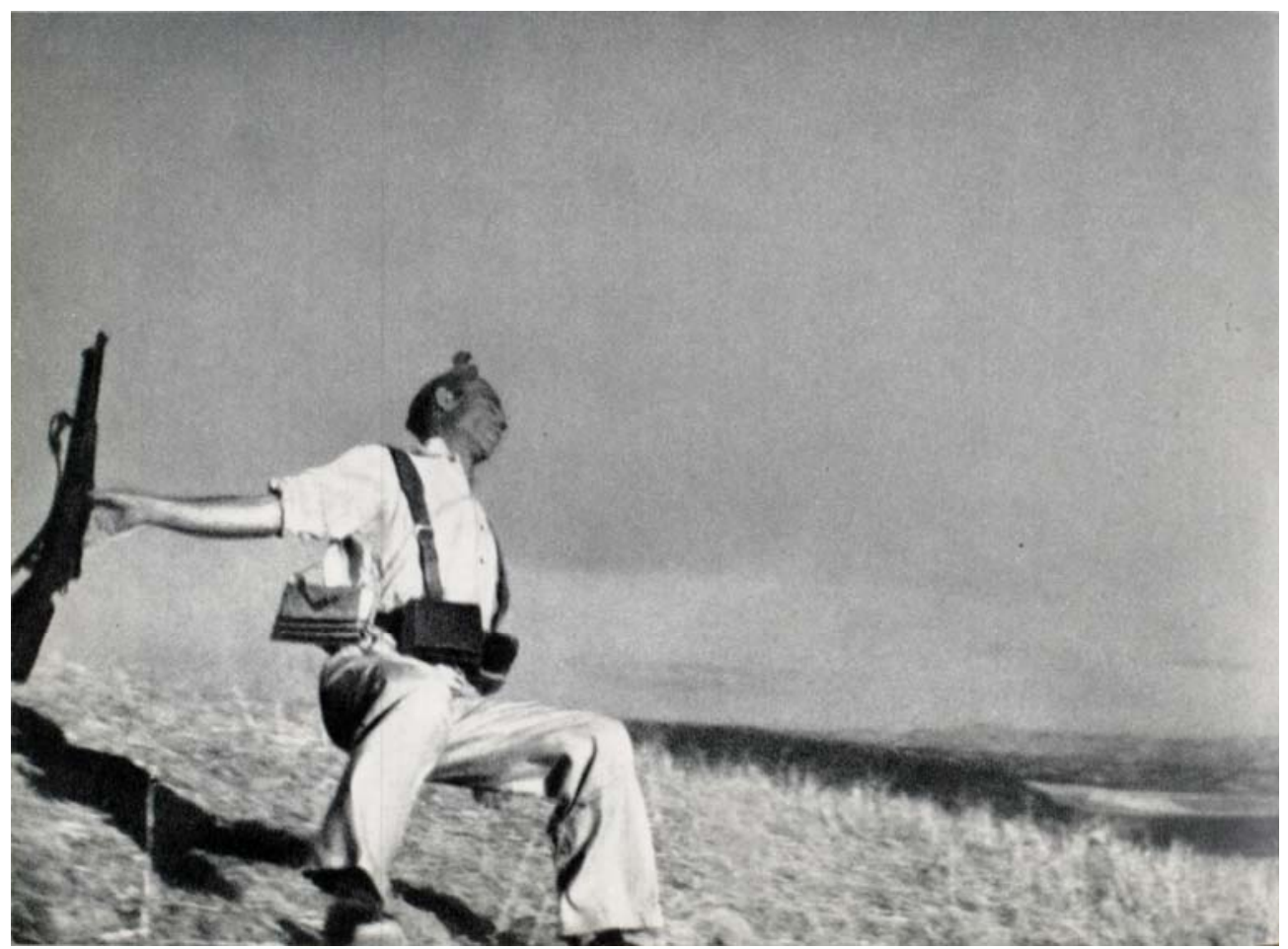


Mesmo a imagem acima que é provavelmente o "instantâneo" mais famoso da história da fotografia e que em tudo atende às exigências de Lissovsky quanto ao tempo, estava originalmente cercada por outras imagens do mesmo evento em uma tira de filme.

As folhas de contato apresentam muitas vezes inevitável semelhança com as imagens produzidas por Eadweard Muybridge, no final do século XIX, para análise de movimentos e que são comumente associados às pesquisas que levaram ao surgimento do cinema.

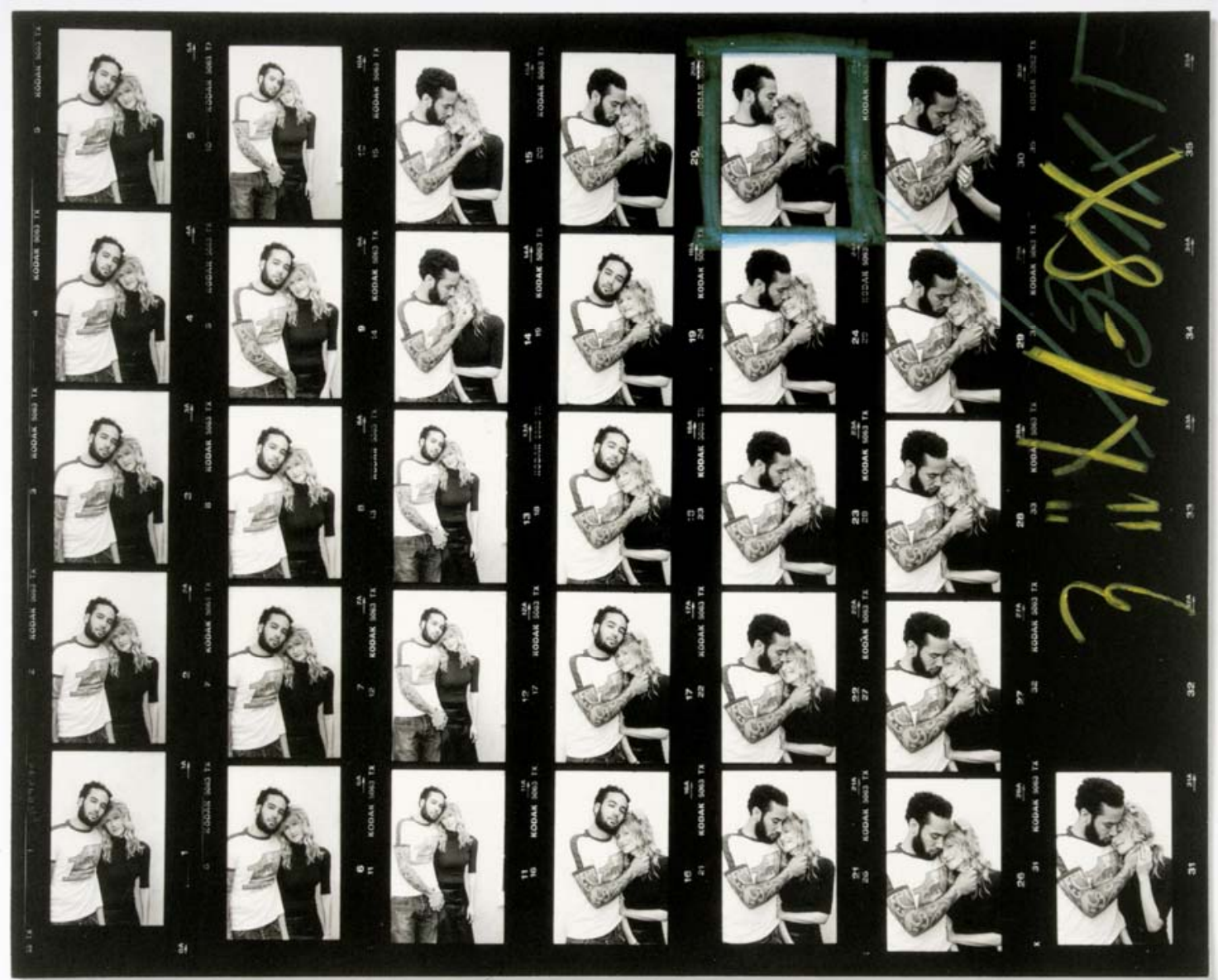




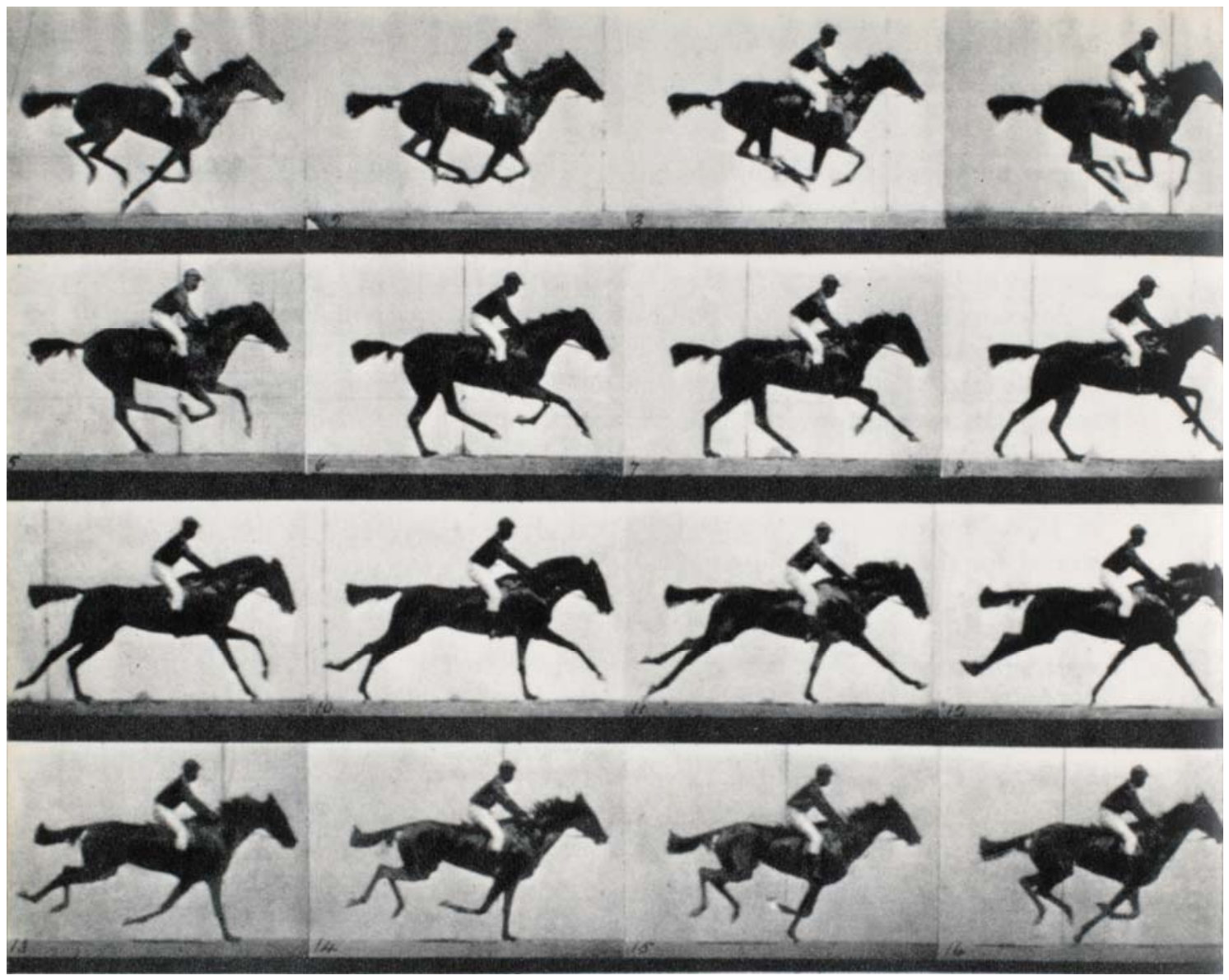

É claro que os contatos quase nunca exibem o rigor formal $\mathrm{e}$ cronométrico dos trabalhos de Muybridge, Mesmo assim, mostram de forma inequívoca o desenvolvimento de um processo espacial-temporal e permitem analisar não só o movimento do assunto fotografado como também o movimento do fotógrafo com relação à cena, permitindo que se vislumbre como foi o desenrolar do evento que constituiu o registro das imagens.

A esse respeito, Tisseron comenta que:

O conjunto de gestos com que a pessoa que fotografa se desloca, se aproxima ou se afasta do assunto, gira, enquadra no visor, aperta o disparador, avança o filme para, 
conforme o caso, disparar de novo, participa na operação de simbolização do acontecimento, na forma sensorial-afetivamotora. O enquadramento, em particular, participa intensamente na formalização $e$ apropriação simbólica do mundo. (Tisseron, 2000:26)

A maioria dos amadores nunca mostrou muito interesse pelas provas de contato. Isso se explica, pois sendo feitas manualmente, tinham custo elevado, principalmente quando se tratava de fotografias coloridas. Além disso, exigiam um trabalho de escolha feito a partir de imagens pequenas e na maioria das vezes não completamente satisfatórias, que se apresentavam um tanto claras ou escuras demais e, no caso das fotos coloridas, quase sempre fora do balanço cromático correto, como decorrência inevitável da forma como eram feitas, já que a folha de papel fotográfico recebia uma mesma exposição e revelação em toda sua área, que representava solução média de compromisso entre os negativos mais claros e mais escuros do filme. E havia ainda um problema mais sério: a necessidade de tomar decisóes, que a maioria dos amadores sempre preferiu evitar.

A idéia de revelar e copiar todas as fotos não foi propriamente uma novidade dos tempos da fotografia colorida, pois as primeiras câmaras vendidas pela Kodak para amadores, ofereciam autonomia para fazer até 100 fotos antes de serem devolvidas ao laboratório do fabricante para revelação e copiagem. O fotógrafo recebia cópias de todas as fotos feitas, ficando por conta de sua avaliação decidir quais mereciam ser guardadas, e quais seriam descartadas. A diferença é que nessa época o formato dos negativos era bem maior e as copias, em preto e branco, se faziam por contato, copiando o rolo de negativos sobre uma fita de papel fotográfico também em rolo. 
O processamento manual de cópias coloridas era bastante caro o que tendia a complicar a situação. Com o advento de equipamentos automatizados de revelação e copiagem, os laboratórios começaram a oferecer uma opção que era bastante atraente para os amadores e que consistia em revelar o filme e copiar todas as imagens por um preço fixo. Não havia a despesa da prova de contato e não era preciso decidir quais fotos deixariam de ser ampliadas. Ficava mais fácil selecionar as cópias em tamanho maior, normalmente $9 \times 12 \mathrm{~cm}$ ou $10 \times 15 \mathrm{~cm}$ e já ajustadas individualmente, se bem que forma um tanto grosseira pelos equipamentos automáticos de então. No fim das contas, acabava até ficando mais barato do que pagar a prova de contato e ampliar apenas uma parte dos negativos. E não havia a dolorosa tarefa de tomar decisões. Afinal, as imagens ruins, nem precisavam ser jogadas no lixo, pelo menos não na época em que foram feitas, sempre havendo um pequeno espaço em alguma gaveta que permitia deixar isso para depois.

A opção já existia anteriormente para fotos em preto e branco, mas o preço do serviço era calculado a partir de um valor unitário por cada foto feita. Tinha lógica, pois as operações eram quase sempre feitas manualmente, mas isso fazia com que não fosse economicamente interessante. A novidade era o preço fixo, que posteriormente alguns laboratórios transformaram em preço máximo, do qual se subtraia um valor unitário para cada cópia muito clara ou escura, ou ainda pouco nítida, que o cliente considerasse como insatisfatória. Indo além da concorrência comercial entre os laboratórios, a existência de tal proposta evidencia que as empresas contavam com um grau de exigência não muito elevado por parte dos amadores e também com o fato de que a maioria preferia pagar para ficar com a foto do que receber o desconto mas ter que assistir à cena de ver a foto da namorada ou do filho, mesmo não muito boa, ser rasgada e jogada no lixo. 
Essa operação de revelação e extração de ampliações automáticas de todos os negativos, pensada basicamente para uso dos amadores, acabou sendo usada por diversos profissionais que achavam mais cômodo examinar as cópias em tamanho maior para selecionar quais seriam ampliadas. Isso era particularmente útil quando o processo de seleção envolvia outras pessoas além do fotógrafo, como no caso de fotos de casamentos ou eventos comerciais.

O conjunto das cópias soltas formava uma espécie de baralho e a organização cronológica das imagens rapidamente se perdia. Os laboratórios começam a incluir no serviço um pequeno álbum com folhas transparentes para manter as fotos de forma organizada, servindo ainda como proteção contra mãos nem sempre muito limpas.

Fugindo do arranjo cronológico linear, as fotos espalhadas em cima de uma mesa podiam lembrar também uma grande folha de provas. 

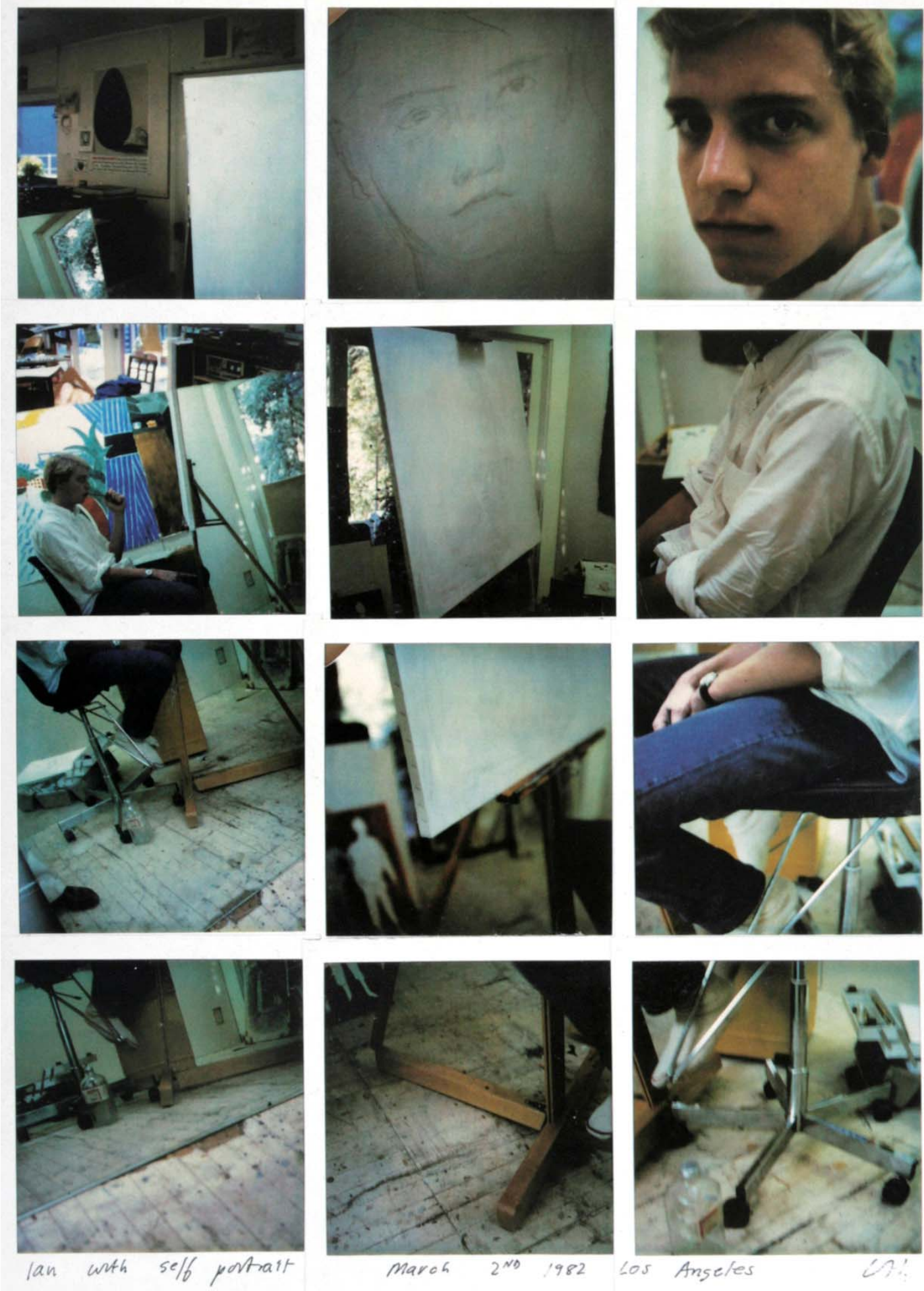

David Hockney usou imagens feitas câmaras tipo Polaroid para fazer suas primeiras fotomontagens, mas a maior parte de seus trabalhos desse tipo mostra que logo ele acabou optando pelo formato $35 \mathrm{~mm}$ e cópias 
comuns sobre papel feitas em máquinas automáticas de laboratórios comerciais de foto acabamento.

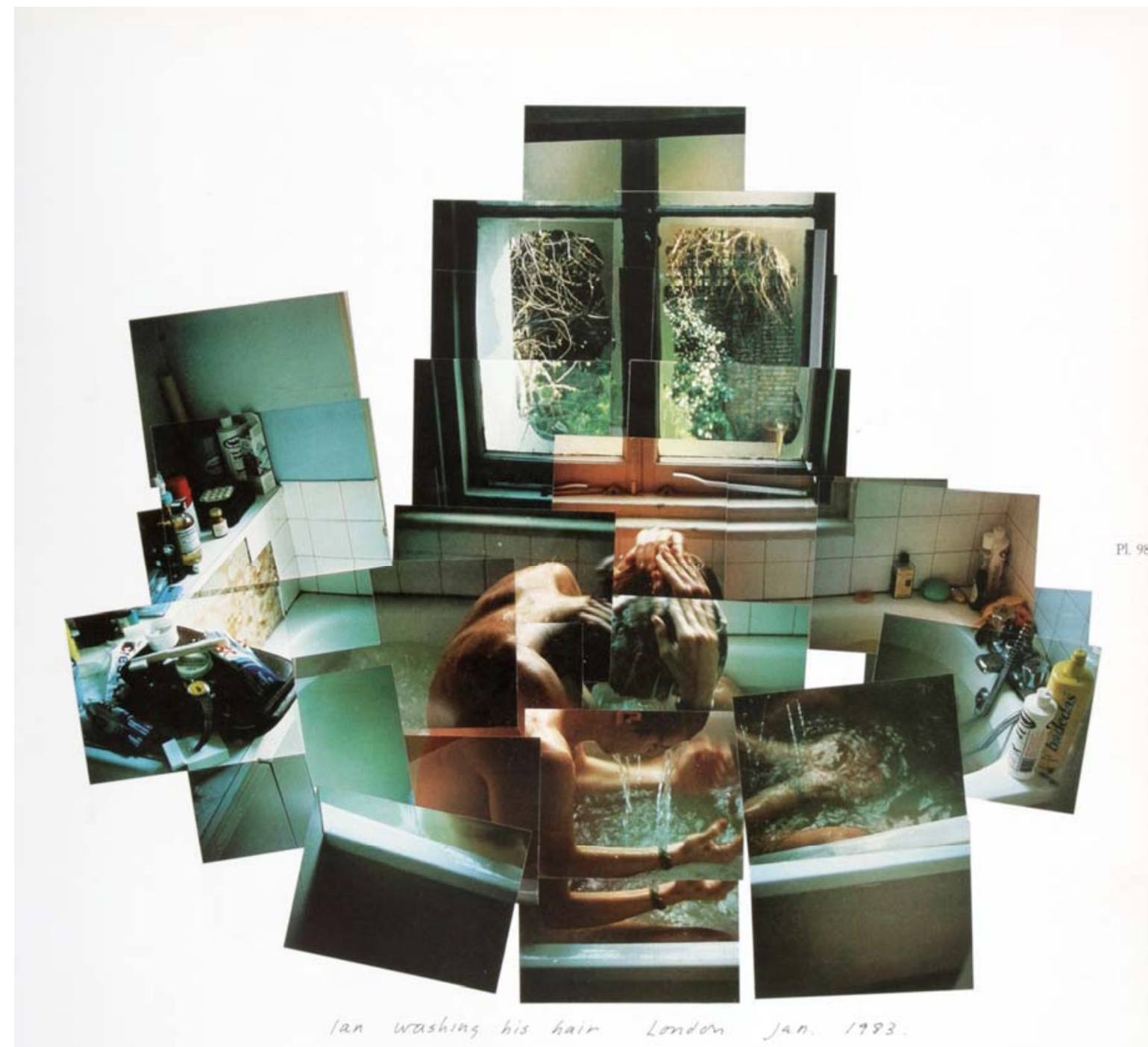

Essas montagens mostram uma representação fragmentada do espaço de inegável influência cubista, completamente diferente da linearidade das folhas de contato, e isso se deve, é evidente, não apenas ao arranjo espacial, mas principalmente às decisóes do autor em termos de enquadramento e composição. Mesmo assim, deixam claro que o trabalho com um conjunto de provas ou uma folha de contatos pode ir muito além de apenas escolher algumas e descartar outras. 
Tisseron, mostra interesse por essa questão, quando comenta que

$$
\begin{aligned}
& \text { "Os fotógrafos profissionais escolhem } \\
& \text { determinadas imagens de suas folhas de } \\
& \text { contatos, mas isso não os leva a destruir as } \\
& \text { outras. Sabem muito bem que seus } \\
& \text { "fracassos" de hoje podem vir a ser os } \\
& \text { "sucessos" de amanhã, quando seu olhar ou } \\
& \text { a expectativa do público possam ter } \\
& \text { mudado. Sua seleção obedece não tanto a } \\
& \text { uma opinião definitiva mas antes ao desejo } \\
& \text { de salientar uma continuidade em sua } \\
& \text { obra." (Tisseron, 2000:132) }
\end{aligned}
$$

Recentemente o fotografo Jim Marshall publicou um livro chamado Proof em que mostra folhas de contatos de seus trabalhos ao lado da foto selecionada em tamanho maior. É um trabalho interessante que permite vislumbrar como ocorre esse processo de busca e amostragem da cena durante a captação e a posterior reorganização em busca da síntese visual.

Fotógrafos que operam com câmaras de chapas podem usar desenvolver sofisticados procedimentos como o "Zone System" para controle da escala tonal, imaginado por Ansel Adams e pelo qual após análise das características tonais de uma cena, se definem padróes de exposição e processamento para obter determinada resposta tonal desejada.

Isso exige condições particulares de exposição e processamento para cada cena, o que inviabiliza seu uso com rolos de filmes já que é praticamente impossível processar de forma diferenciada cada imagem registrada sobre um rolo de filme. 
Eleanor Lewis editou em 1977 um livro chamado Darkroom. Nesse livro ela entrevista vários fotógrafos sobre os procedimentos de finalização das imagens que produziam. Nesse trabalho ela pode constatar que alguns fotógrafos gostavam do trabalho de laboratório enquanto outros o detestavam. Outros ainda pareciam não mostrar muito interesse pelo assunto, entregando simplesmente seus filmes para algum laboratório processar e copiar.

Entre os não gostavam aparece a figura de Eugene Smith que declara:

"Não há nada na fotografia que eu odeie mais do que a disciplina do laboratório, e mesmo assim, eu passei todos esses anos fazendo cópias. O motivo (reason) é muito simples. Eu quero que as malditas imagens digam o que eu quero que elas digam. Eu quero atenuar as coisas que não tem importância para a afirmação da imagem e quero ter certeza de que as coisas importantes vão estar límpidas, claras $e$ diretas. Fazer as minhas próprias cópias é a única forma de completar o que eu vi quando fiz a foto." (SMITH in LEWIS, 1977:145)

Não sem ironia, a autora aproveita para reforçar a declaração colocando a fotografia abaixo, de Smith em seu laboratório. 


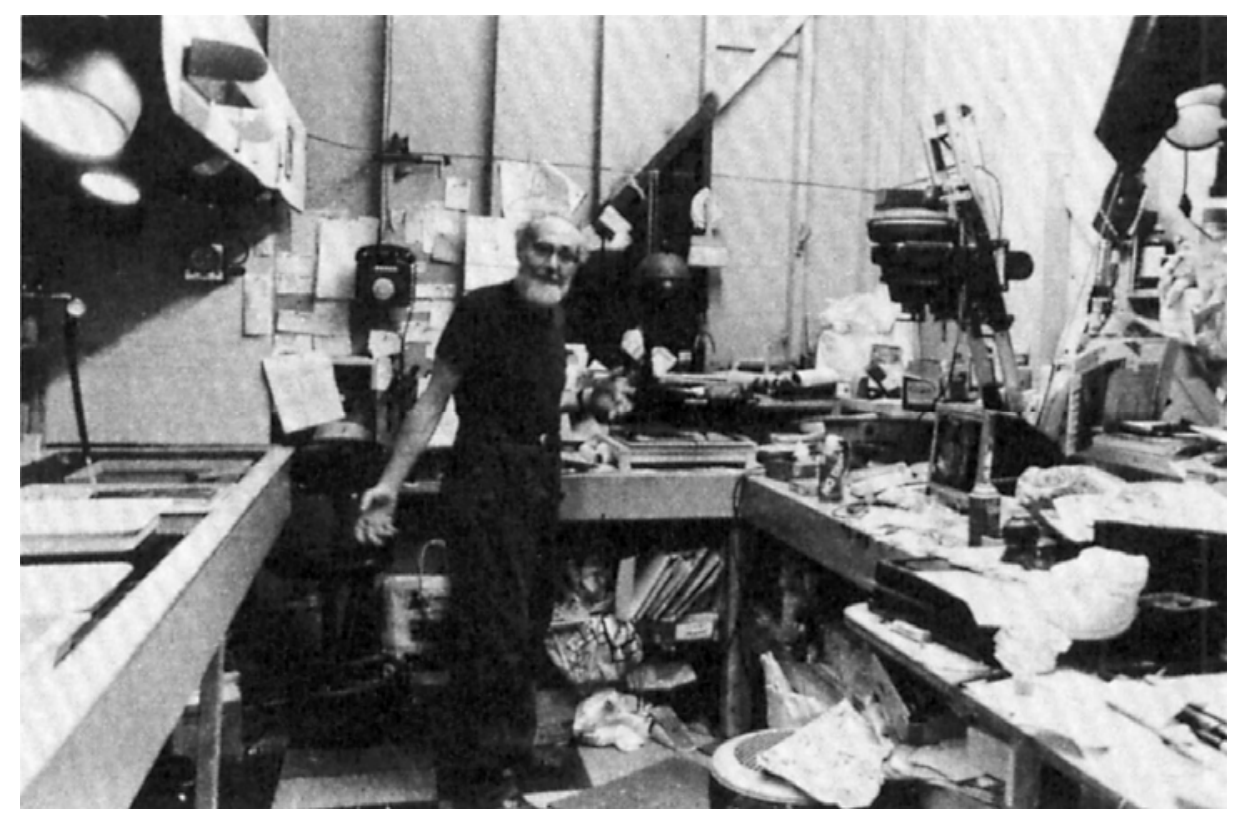

Eugene Smith trabalhou também com o formato $35 \mathrm{~mm}$ e produzia negativos em quantidade para causar problemas na hora da revelação dos filmes. Ele chegou a desenvolver uma técnica de carregar dois filmes simultaneamente em cada suporte espiral, para poder agilizar o trabalho, como se vê na imagem abaixo.

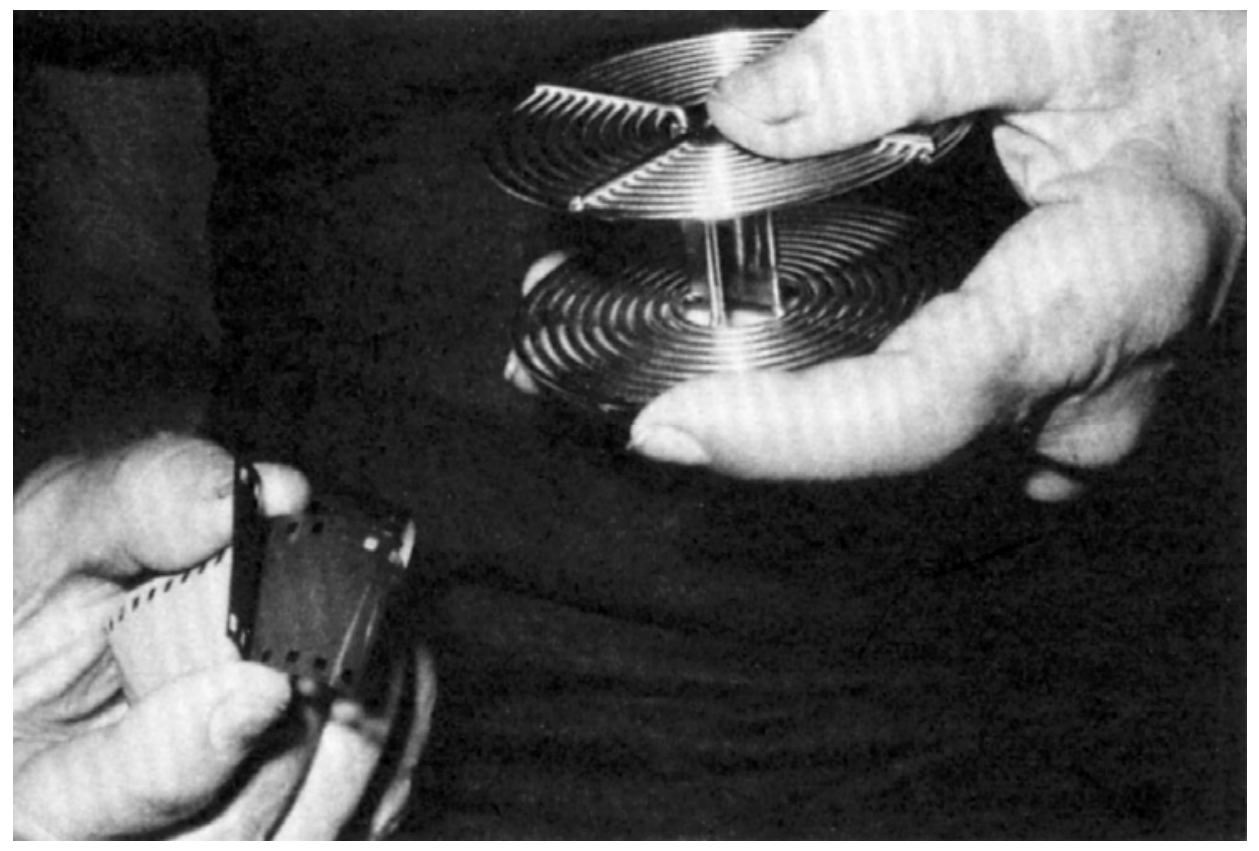


É importante observar que esse procedimento assume razoável risco de dano em algumas imagens o que não parecia preocupar Smith. A partir disso, parece razoável supor que ele considerava aceitável a eventual perda de alguns fotogramas, considerando a produção pelo conjunto dos negativos mais do que por cada imagem particularmente.

Lewis descreve as etapas do trabalho de Smith e algumas fotos ilustram os instrumentos e procedimentos que o fotógrafo faz questão de usar pessoalmente para garantir o resultado desejado nas imagens que produz.

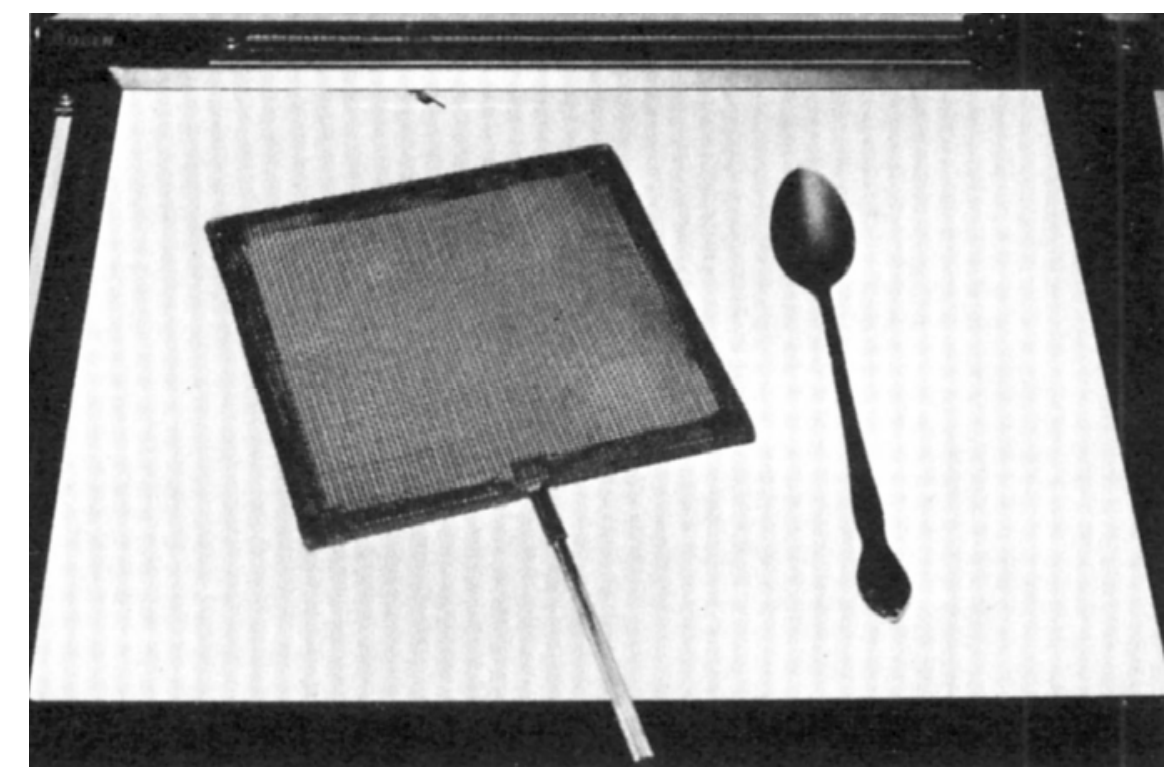

Instrumentos para controle da luz durante a ampliação 


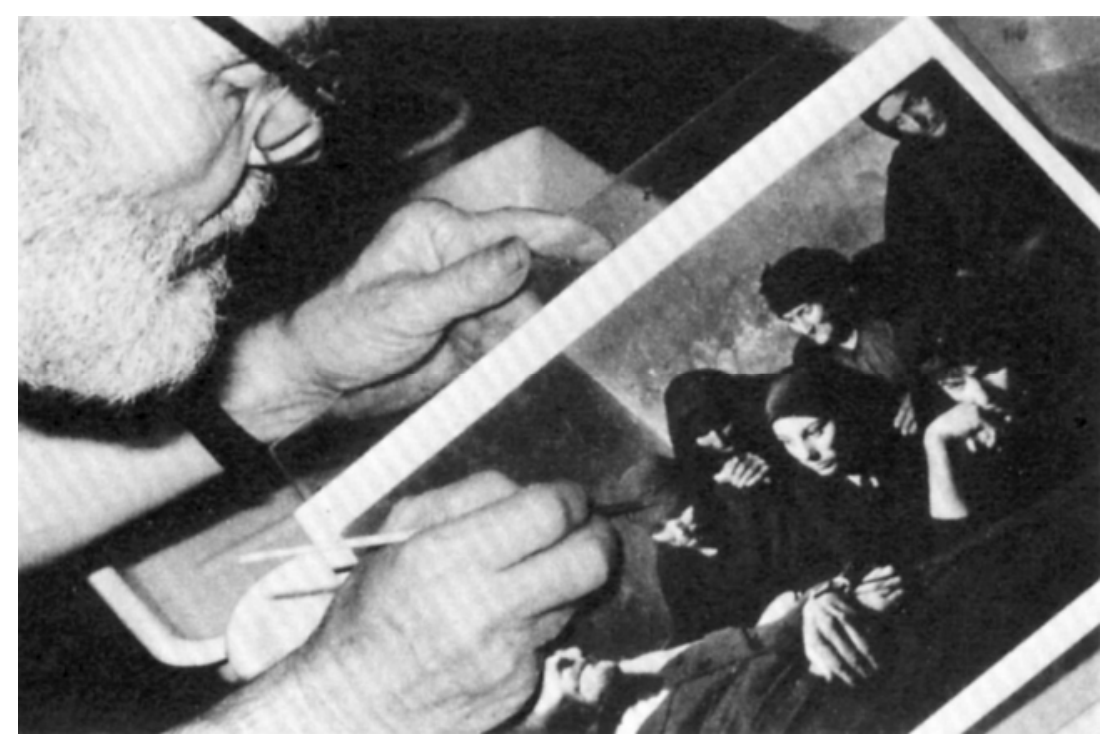

Retoque químico para clarear sombras

A atitude de Weston é compatível com a análise de Tisseron quando este afirma:

O fotógrafo sempre age com o desejo de "criar" uma imagem que antes não existia. Esse desejo gera esperança e angústia: “Será que a foto vai ficar boa ?" ele sempre se questiona. Veremos como por trás disso se oculta o desejo de obter um esclarecimento do mundo por meio de sua imagem. (Tisseron, 2000:14)

Richard Avedon não fazia ele mesmo suas cópias, mas passava instruções minuciosas para o laboratório encarregado. Tisseron se mostra impressionado com a evidente busca de significação implícita nessas instruções de comando.

"O nível de detalhes nas instruções passadas para a copiagem do retrato intitulado Lyal Bur, minerador, e seus filhos 
Kerry e Phillip explicita esses procedimentos. Na imagem distribuída ao público por Avedon, o rosto do pai impõe uma presença e uma intensidade totalmente ausentes nos rostos dos filhos que estão ao seu lado. Seu olhar parece "saltar" realmente do plano da imagem. Pois bem, a minuciosidade das instruções dadas por Avedon para a copiagem desse rosto mostra um cuidado rigoroso no sentido de acentuar o contraste entre as aberturas dos olhos e as áreas adjacentes mais próximas. Partindo do tempo geral de exposição, se indica [-4] para os olhos, [-6] para as partes inferiores das pálpebras, enquanto que as áreas mais próximas recebem uma acentuação na exposição indicada como [+20] logo abaixo das pálpebras, [+30] no canto externo dos olhos e [+40] acima das sobrancelhas. Usando meios artificiais, se fez com que o olhar de Lyal Bur pareça resplandecente no momento da copiagem.” (Tisseron, 2000:96)

Parece evidente que quando Couchot se refere à interação homem diz que pode ficar a impressão enganosa de que o fotógrafo abriu mão da escolha do "momento decisivo" entregue a um mecanismo automático. Ocorre que a decisão não foi entregue ao equipamento, mas apenas postergada para uma etapa de pós-produção, muito semelhante ao trabalho clássico de seleção de imagens. 
Nesse sentido, a edição digital de imagens pode ser considerada essencialmente semelhante ao trabalho que Smith fazia em seu laboratório, com colheres, peneiras ou pincéis. E a edição inter-imagens, antes vista como mais ligada ao domínio da gravura do que ao da fotografia, surge como conseqüência da captação seqüencial usando câmaras motorizadas (ou digitais).

A física quântica mostrou que, nas medições experimentais, os valores registrados dependem do ponto de vista do observador que, por sua vez, interage com as leituras.

Assim, pode ser razoável que o "momento decisivo" esteja em algum ponto entre as diversas imagens ou mesmo parte dele em uma imagem e parte em outra.

Um evento recente ocorrido durante a guerra do Iraque pode servir para ilustrar isso:

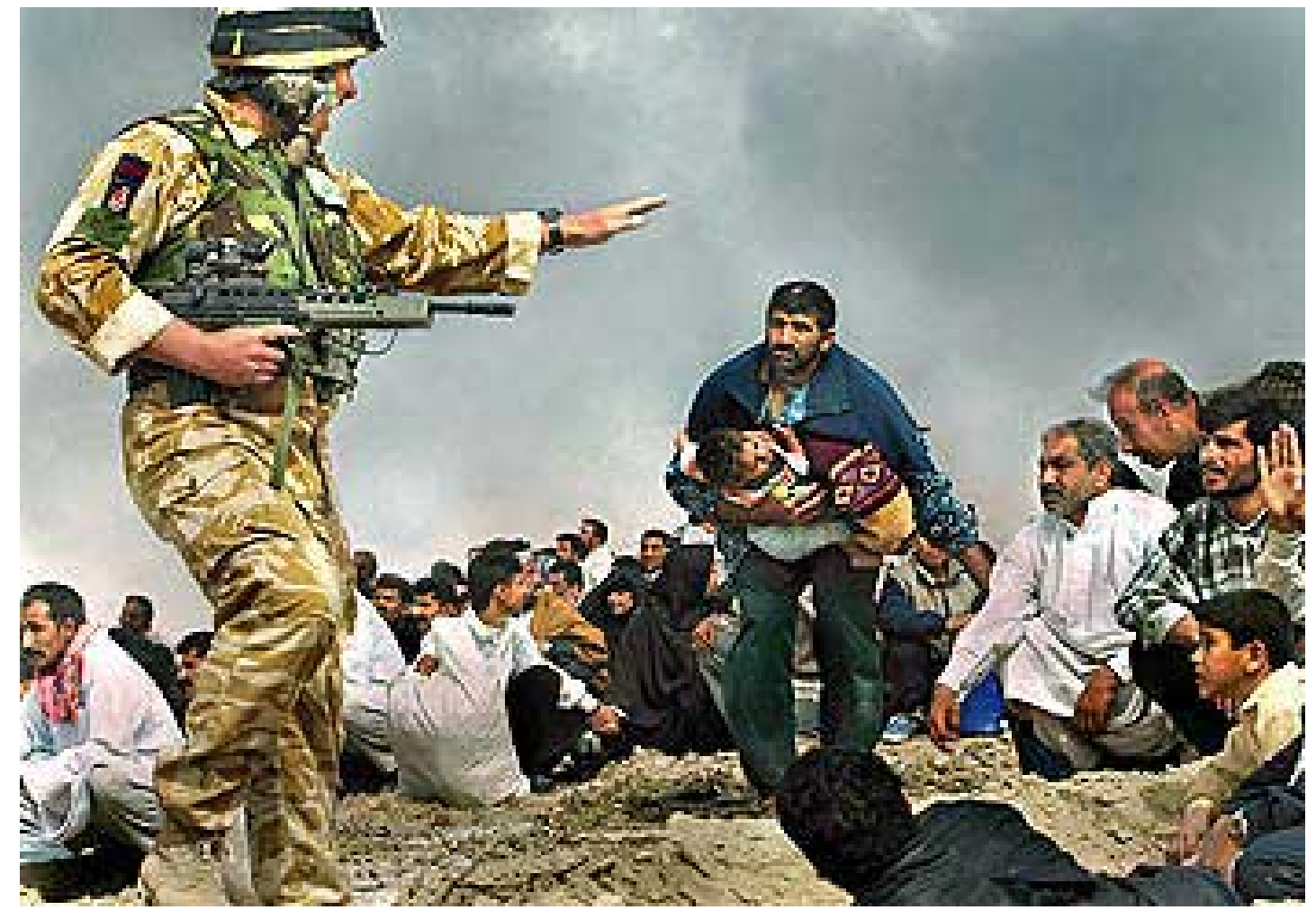


A imagem acima foi publicada por muitos jornais do mundo, com grande repercussão. Cerca de uma semana depois saiu a notícia de que o foto jornalista havia sido demitido por ter manipulado a fotografia que seria na verdade resultado da edição das duas imagens abaixo
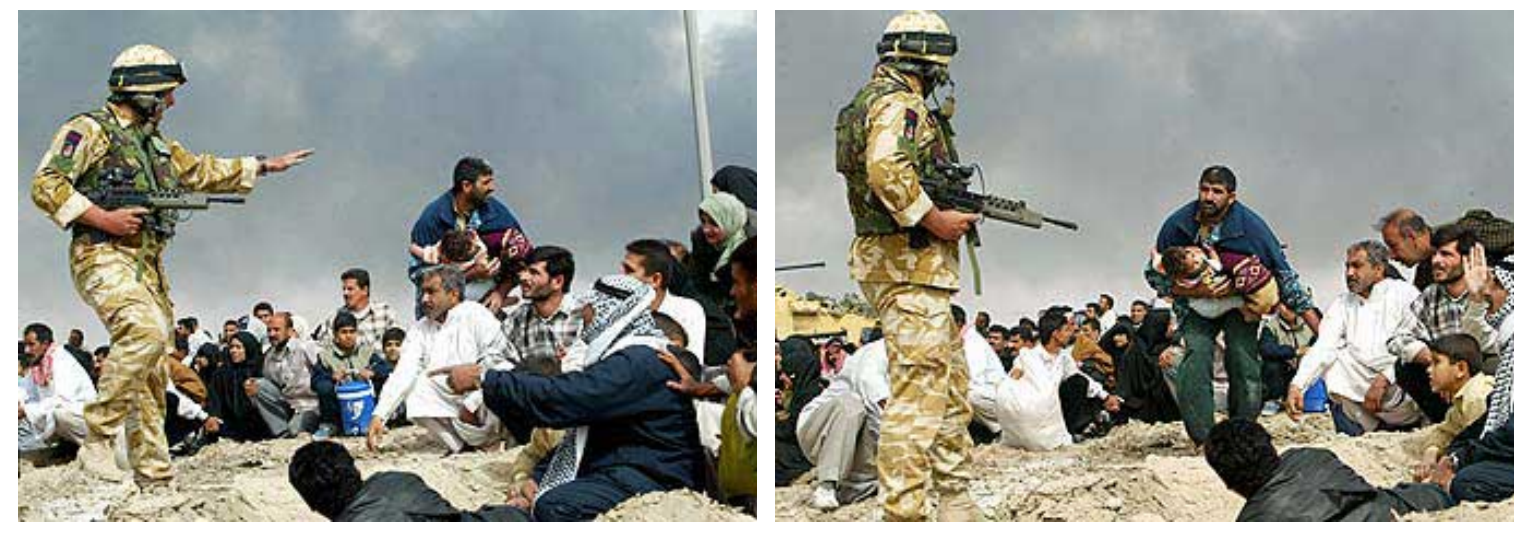

Pode ser repreensível o fato de que o autor escamoteou a informação sobre o feto de ter editado as imagens, mas parece inegável que a imagem final traduz de forma superior a "significação" da cena.

Importa lembrar que essas interações de imagens remontam aos primórdios da fotografia, mas feita com grandes dificuldades técnicas e no geral como demonstração de virtuosismo, como no caso da célebre montagem de Valério Vieira denominada "Os 30 Valérios", mas que foi usado muitas vezes para produzir imagens documentais fraudulentas como as figuras políticas apagadas da cena ao saírem das graças de algum ditador de plantão.

Ao fotografar grupos de pessoas e em particular de crianças a grande dificuldade é conseguir uma única foto em que não haja alguém de olhos fechados, fazendo caretas etc. A técnicas digitais de edição ofereceram uma solução simples para os fotógrafos.

São feitas várias fotos em seqüência e depois sobrepostas, como se vê na imagem abaixo em que cada camada representa um diferente instante no tempo. 


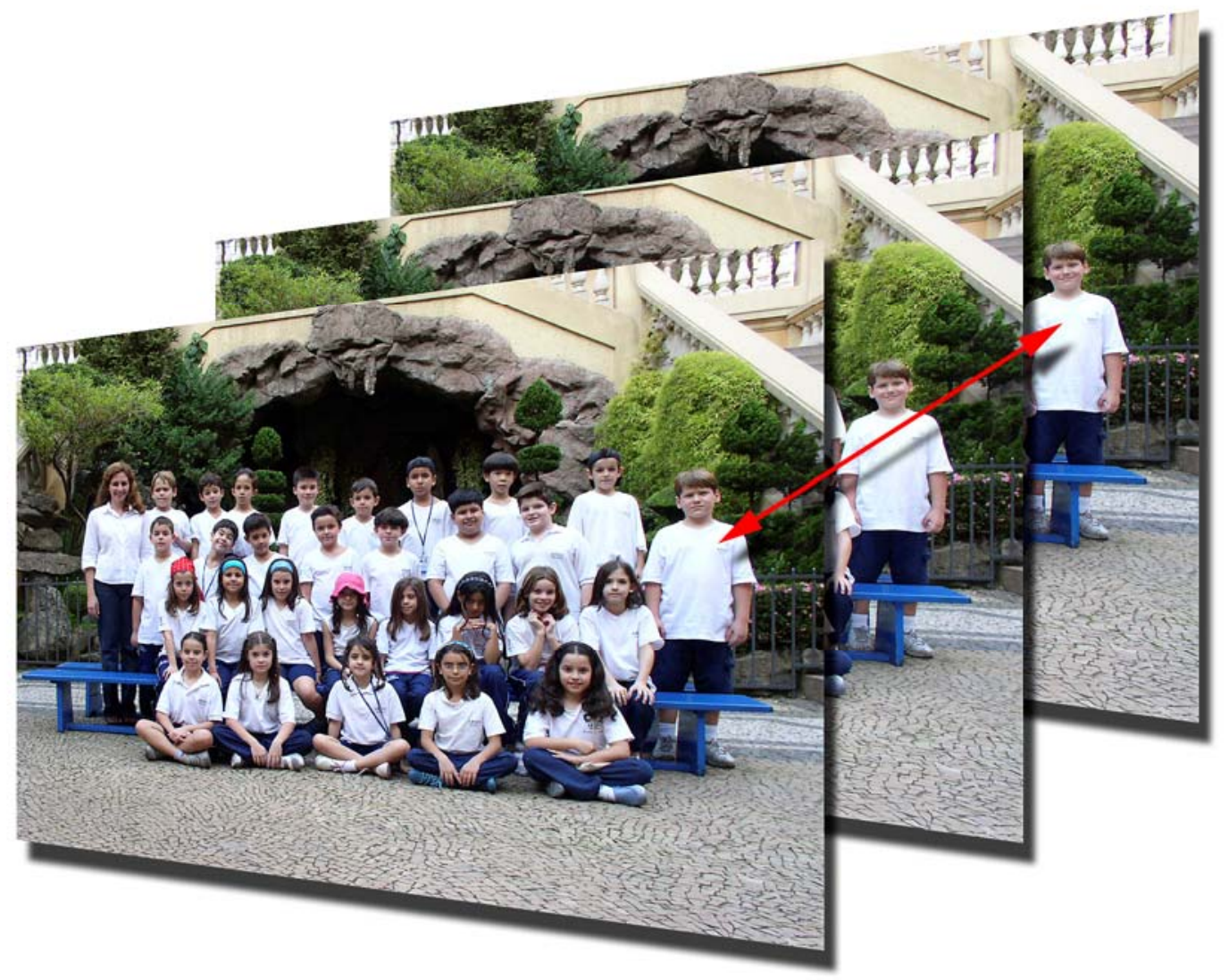

Usando uma técnica simples de máscara a imagem final mostra as diversas pessoas, no mesmo local, mas em momentos ligeiramente diferentes. É interessante que isso representa em escala microscópica a analogia que Barthes faz ao dizer que

"A foto é literalmente uma emanação do referente. De um corpo real que estava ali, são partes das radiações que vêm me tocar, eu que estou aqui; pouco importa a duração da transmissão; a foto do ser desaparecido vem me tocar como os raios atrasados de uma estrela." (BARTHES in DUBOIS, 1990: 60) 
Em tempo, uma imagem recente que foi objeto de intensa polêmica, mostrava um turista no alto de uma dos edifícios do WTC no dia do atentado, em uma foto que teria sido feita a partir de uma câmara encontrada entre os escombros.

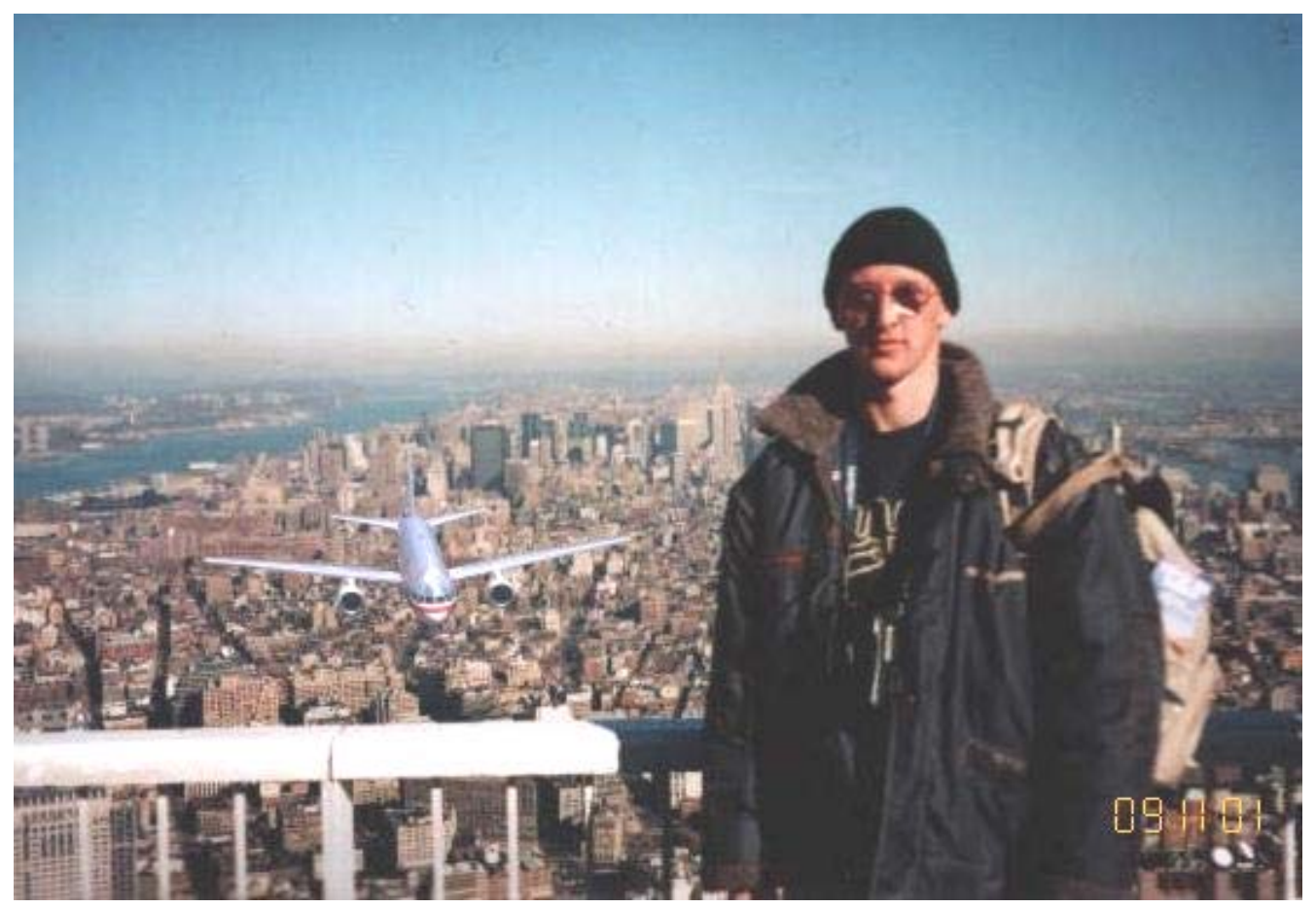

Ao fim de algum tempo, acabou surgindo o fato de que a pessoa que aparece na foto foi quem fez a montagem e colocou a imagem na Internet. Ele não podia se mostrar como autor, pois supostamente estaria morto.

Independente disso, a imagem é uma demonstração eloqüente da análise de Tisseron quando diz que:

A mente não relembra os traumatismos do passado de forma passiva, esperando que o trabalho do tempo atenue progressivamente o sofrimento. Não experimenta os retornos 
como uma fatalidade inevitável. Ao contrário, a vida psíquica de cada um é portadora do desejo de superar os traumas mediante um trabalho de simbolização. Por isso a imagem -e a fotografia especialmente - não é um modo de repetir o trauma mantendo-o inalterado. (Tisseron, 2000:141).

Nesta imagem, esse processo é tão marcante e a questão do tempo se impõe com tal força a ponto de o autor, mesmo se referindo a um evento de extrema magnitude, não deixar de colocar a data no canto inferior direito da imagem, como uma assinatura. Se o meio é a mensagem, neste caso o tempo (o momento) passa a ter o estatuto de grife, que autentica $o$ valor da obra. 
CAPITULO 6

Conclusão 
O surgimento da fotografia significou etapa importante na automatização do registro das imagens. Ela ocorre como uma extensão da aplicação de equipamentos como a câmara escura, usada inicialmente como ferramenta auxiliar na prática do desenho e da pintura, colocando uma chapa sensível à luz no lugar em que ficava a folha sobre a qual o artista desenhava. De onde se origina o próprio nome do processo: foto $=$ luz e grafia $=$ escrita.

A evolução se dá a partir da automatização da formação da imagem indo para a automatização do registro da imagem formada. Durante várias décadas desde seu surgimento, fazer uma foto era uma operação muito demorada. A causa dessa demora era tanto a pouca sensibilidade das chapas que tornava obrigatório o uso de longos tempos de exposição, bem como a necessidade de preparar as chapas logo antes de seu uso.

Mesmo sendo o registro automatizado, o tempo que se levava para fazêlo não era mais curto do que fazer um desenho, sendo provavelmente até mais demorado. De forma semelhante ao desenho, também as fotos eram produzidas uma de cada vez. O trabalho de registrar a imagem era feito pela energia da luz e não pela mão do artista, mas pode-se considerar que a hierarquia na seqüência operações, descrita por Alberti no seu célebre tratado "De Pictura", guardava razoável semelhança entre a fotografia e a pintura.

A evolução do processo fotográfico conduz a um conjunto de características que fazem com que ele se distancie do desenho e da pintura. Dentre as características que mais determinaram essas mudanças podemos destacar: o aumento da sensibilidade dos filmes e a invenção dos filmes em rolos, usando emulsões secas. A maior sensibilidade permitia obter registros muito mais rapidamente, enquanto 
os rolos de filmes tornavam viável fazer várias fotos em seqüência, bastando enrolar o filme até o pedaço seguinte, que não havia ainda sofrido a ação da luz.

O tempo de exposição era um severo fator limitante durante as primeiras décadas de existência da fotografia e isso tornava muito evidente a sua participação no processo. $\mathrm{O}$ aumento da sensibilidade dos filmes junto ao desenvolvimento de objetivas mais luminosas e com os formatos menores (isto é, menor área de filme para ser exposta), possibilitou o uso de tempos de exposição cada vez mais curtos. Ao longo do século XIX, o tempo de exposição diminuiu, saindo da ordem de unidades de horas para chegar a centésimos de segundo, uma variação de mais de um milhão de vezes. Tão logo os tempos de exposição atingiram valores suficientemente curtos para escapar à percepção do operador, surge o conceito de "instantâneo", e junto com ele nasce a falsa idéia de que o tempo havia desaparecido da fotografia.

Mesmo considerando que, para fazer uma fotografia não se exigia mais a habilidade de saber desenhar ou pintar, o processo continuava sendo muito complexo e caro, fazendo com que poucos conseguissem dominálo.

A idéia de que era real a possibilidade de qualquer pessoa poder registrar imagens, fez com que a indústria procurasse desenvolver meios de simplificar o processo e reduzir custos para conquistar um número cada vez maior de consumidores para seus produtos. O slogan criado por George Eastman: "você aperta o botão, nós fazemos o resto" talvez represente a melhor síntese desse esforço. $O$ meio fotográfico se populariza e o aumento na quantidade de imagens produzidas mostra uma importante diferença com relação às técnicas anteriores. 
Começa a ocorrer certa ruptura na hierarquia clássica prescrita por Alberti para a produção de imagens. A facilidade e a rapidez na produção de fotos, bem como o custo que se reduz junto com o formato dos filmes, levam a uma situação em que se fotografa muito, deixando para depois da revelação a escolha das imagens mais bem sucedidas em termos de enquadramento, composição e, muitas vezes até, exposição.

Mas, no fim das contas, só se vêem as imagens escolhidas, não as demais que foram descartadas. Muitas análises críticas do meio fotográfico levam em conta somente esse resultado final, como se ele tivesse sido produzido, dentro dos moldes clássicos, apenas de forma mais rápida e automatizada.

A observação mais cuidadosa mostra, contudo que essa automatização no registro da imagem está muito longe de ser "objetiva” como o pressupõe o nome dado ao sistema ótico que forma as imagens. As diversas soluções técnicas utilizadas nos projetos dos equipamentos determinam também diferenças significativas na forma como as imagens são registradas. Além disso, o processo negativo-positivo permite toda uma série de intervenções durante a etapa de copiagem e em pouco tempo essas intervenções deixam de ser feitas apenas por razões técnicas, transformando-se em verdadeiras ferramentas de linguagem visual. Fica claro, enfim, que a análise crítica da fotografia precisa considerar não apenas o produto acabado, mas sim seu processo de produção como um todo, um objeto complexo que se pode denominar “ato fotográfico".

Ao se deslocar o foco para o processo como um todo, uma das primeiras providências deve ser a de incluir na análise, não apenas as imagens finais selecionadas, mas sim a totalidade do conjunto das imagens produzidas de uma determinada cena, mesmo as que por qualquer motivo foram descartadas. A primeira conseqüência disso é que, mesmo sendo muito curto o tempo de exposição de cada foto quando se 
considera o processo como um todo, incluindo a produção das várias versões de uma mesma cena, a questão do tempo não apenas ressurge, mas se impõe de forma completamente diferente.

Uma fotografia pronta é o resultado de um processo complexo, que se inicia com uma experiência sensorial e só vai se completar com a introjeção psíquica dessa experiência.

Em resumo:

1 - A evolução do processo fotográfico, que surge como uma derivação de certas ferramentas de pintura e desenho, ao longo de sua evolução se afasta significativamente dessas técnicas clássicas e passa a ter uma existência autônoma.

2 - Os registros fotográficos, como qualquer outro processo físico, são limitados sempre pelas constrições técnicas do meio, definindo o espaço de uma sintaxe. A evolução técnica do meio modifica esse quadro produzindo alterações no espaço sintático, geralmente no sentido de ampliá-lo.

3 - Um raciocínio lógico simples permite dizer que:

a) a sintaxe, em qualquer momento e/ou patamar técnico define limites, portanto, permite atingir quaisquer resultados pretendidos;

b) o desenvolvimento do meio modifica as condições de uso, permitindo então resultados que anteriormente não eram possíveis;

c) o uso desses recursos representa uma utilização sintática do meio e a sintaxe não apenas estabelece limites, mas principalmente mapeia a amplitude dos recursos disponíveis.

4 - A prática do processo fotográfico varia com as características dos equipamentos operados. Limitada por eles em alguns aspectos, 
aproveita, contudo, as possibilidades abertas por outros. A diminuição dos formatos junto com a automatização das operações de focalização, exposição e transporte do filme produziram uma alteração nessa prática, fazendo com que ela se afastasse dos procedimentos associados à câmara escura, que é o instrumento que está na sua origem e se aproximasse dos procedimentos do cinema, onde se faz uma captação abundante de imagens para posterior edição.

5 - O processo fotográfico opera com elementos que transcendem as questões técnicas da sintaxe e se situam no âmbito da percepção e da vida psíquica não apenas do fotógrafo, mas também dos observadores e dos assuntos das fotos.

6 - As etapas de análise e avaliação das imagens bem como as decisões de exibi-las, guardá-las, ou mesmo, destruí-las, são dependentes de um complexo processo psíquico no qual entra em jogo a busca de um equilíbrio entre a memória emocional do fato registrado e a avaliação que se faz de como a imagem representa essa memória. Ou seja, tem relação apenas indireta com a cena objetivamente registrada.

7 - Há várias instâncias de tempo ocorrendo no processo fotográfico:

a) um tempo físico que se relaciona com o momento em que cada imagem é registrada e com a energia envolvida nessa operação;

b) um tempo de captação que se relaciona com as operações de interação com a cena e de produzir registros sucessivos da mesma; consideramos aqui essa amostragem como uma fragmentação do tempo da cena;

c) um tempo de edição que se relaciona com as operações de seleção e tratamento das imagens produzidas anteriormente, procurando buscar um equilíbrio entre a leitura que se faz dessas imagens, a memória da cena e, principalmente, a adequação desses dois fatores com $\mathrm{o}$ julgamento que se faz da cena e aquele que se espera que os observadores possam vir a fazer dela; este processo, de busca de uma 
síntese da significação, representa aqui uma condensação do tempo da ação, obtido pela redução à dimensão espacial de um evento que possuía além dela, também uma dimensão temporal.

8 - Nesse sentido, a imagem fotográfica é uma representação visual que, mesmo utilizando processos automatizados de formação e captação das imagens, é tão subjetiva quanto qualquer outra forma clássica de representação visual. 
Referências Tempo 
Referências

TISSERON, S., El mistério de la cámara lúcida, fotografia e inconsciente, Salamanca, Ed. Universidad de Salamanca, 2000.

DUBOIS, P., O ato fotográfico, Campinas, Papirus, 1994.

COX, A., Photographic Optics, $15^{\text {th }}$ ed, London, Focal Press, 1974.

LANGFORD, M.J., Basic Photography, $3^{\text {rd }}$ ed, New York, Amphoto, 1973.

GERNSHEIM, H. \& A., A concise history of photography, London, Thames \& Hudson, 1971.

BARTHES, R., A câmara clara, $2^{\mathrm{a}}$ ed, Rio de Janeiro, Nova Fronteira, 1984.

FONTANILlE, J. \& ZILBERBERG, C., Tensão e significação, São Paulo, Discurso Editorial, 2001.

BURGIN, V., "Uma relectura de La cámara lúcida” (1982) in Ensayos, Barcelona, Gustavo Gili, 2004.

COLLINS, D., The story of Kodak, New York, Abrams, 1990.

EDER, J.M., History of photography, New York, Dover, 1972.

DANZIGER, J. \& CONRAD III, B., Interviews with master photographers, New York, Paddington, 1977.

MANNHEIM, L.A. et. al., The focal encyclopedia of photography, (2 vol), New York, McGraw-Hill, 1977. 
CRAWFORD, W., The keepers of light. A history \& working guide to early photographic processes, New York, Morgan \& Morgan, 1979.

LEWIS, E., Darkroom, New York, Lustrum Press, 1977.

GOLDSMITH, A., The camera and its images, New York, Ridgepress \& Newsweek, 1979.

ARNHEIM, R., El pensamiento visual, Buenos Aires, Ed. Universitária, 1973.

EHRENZWEIG, A., Psicanaálise da percepção artística, Rio de Janeiro, Zahar, 1965.

LARTIGUE, J.H., Les autos et autres engins roulants, Paris, Ed. Du Chêne, 1974.

MEYEROWITZ, J., Cape light, New York, Little, Brown \& Co., 1981.

STROEBEL, L. \& TODD, H.N., Dictionary of contemporary photography, New York, Morgan \& Morgan, 1977

CAPA, C. et. al, The International Center of Photoghraphy encyclopedia of photography, New York, Crown Publishers, 1984.

MARSHALL, J., Proof, San Francisco, Chronicle, 2004.

HOCKNEY, D., Camera works, Alfred Knopf, New York, 1984 